\title{
A Mycobacterium tuberculosis komplex archaikus DNS kimutatása emberi csontvázmaradványokból
}

Ph. D. értekezés

PÓSA ANNAMÁRIA

Témavezetök:

Dr. habil PÁLFI GYÖRGY

Tanszékvezetö egyetemi docens

SZTE TTIK, Embertani Tanszék

Dr. MENDE BALÁZS GUSZTÁV

Csoportvezető, tudományos főmunkatárs

MTA BTK, Régészeti Intézet, Archeogenetikai Laboratórium

Biológia Doktori Iskola

SZTE TTIK, Embertani Tanszék

SZTE TTIK

2017

SZEGED 


\section{Tartalom}

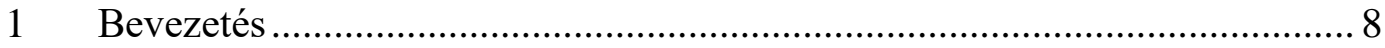

1.1 A tuberkulózis epidemiológiája és paleoepidemiológiája......................... 8

1.2 A Mycobacterium tuberculosis komplex jellemzöi ............................... 13

1.3 A Mycobacterium tuberculosis evolúciója................................................ 16

1.4 A paleopatológiai diagnosztikai módszerek............................................ 18

1.5 Az archeogenetika kialakulása és a molekuláris biológián alapuló archaikus tbc kutatás tudománytörténeti összefoglalása ....................... 21

1.6 Az archaikus DNS tulajdonságai ......................................................... 23

1.7 Egységes kritériumrendszer a kontamináció elkerülésére - a hitelesség

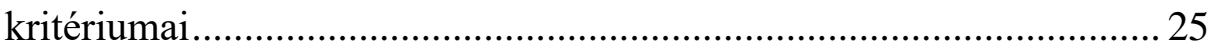

1.8 A mintavételi helyek - a mintavételek lokalizációja ............................ 28

1.9 A fogak alkalmazása a paleomikrobiológiai vizsgálatok során .............29

1.10 Amplifikációmentes vizsgálati módszerek - lipid biomarkerek …….....30

1.11 Újabb irányvonalak az archaikus tbc kutatásban - NGS …………….... 32

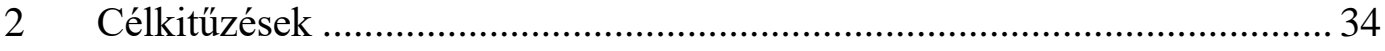

3 Anyagok és módszerek ................................................................................ 36

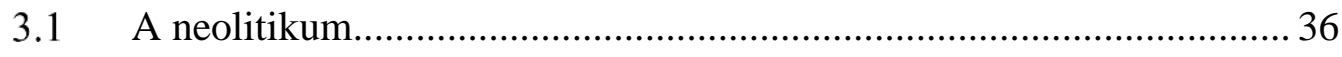

3.1.1 A neolitikum - az újkőkori forradalom ................................................. 36

3.1.2 A földmüvelés, növénytermesztés és a domesztikáció megjelenése a

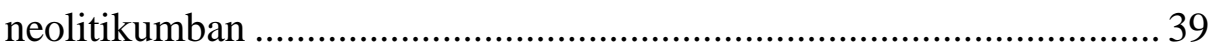

3.1.3 Alsónyék - Kanizsa-dülő lelőhely 13-as sírcsoportja - Lengyel kultúra 40

3.1.4 Vésztő Mágori-domb lelőhely neolit temetője - Tiszai kultúra .42 


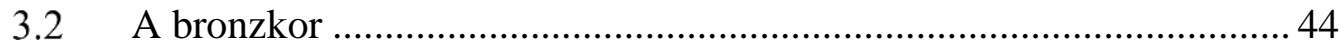

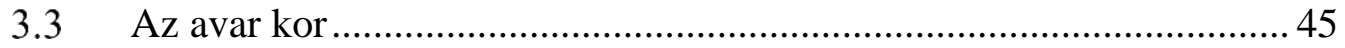

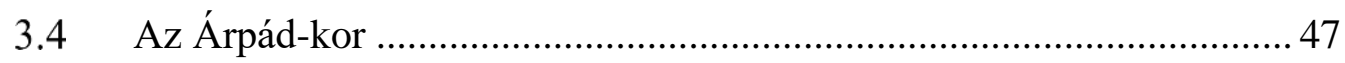

3.4.1 Győr-Pósdomb lelőhelyen feltárt Árpád-kori temető ......................... 47

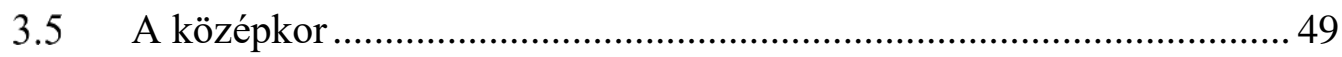

3.5.1 Bácsalmás-Óalmás lelőhely - Egy török hódoltság kori temető .......... 49

3.5.2 A bácsalmás-óalmási széria jelentősége az archaikus tbc kutatásának szempontjából ................................................................................. 51

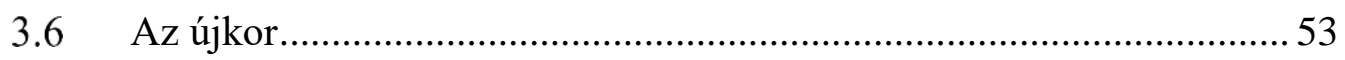

3.6.1 A váci Fehérek temploma: Sándor Terézia maradványai .................... 53

3.6.2 A váci múmiák paleomikrobiológiai jelentősége: tbc az antibiotikumok

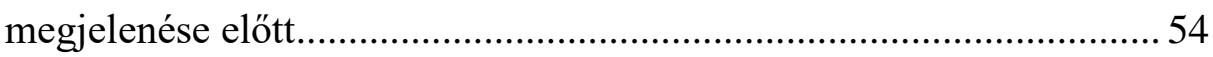

3.7 Különböző archaikus patogén DNS izolálási metodikák alkalmazása

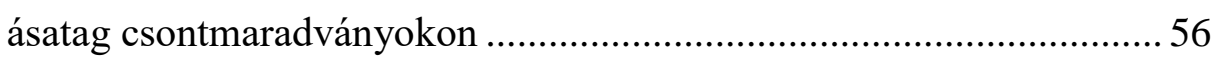

3.8 A csontmaradványokból történő DNS izolálás ................................... 59

3.8.1 A csontminták előkészítése és porítása...........................................59

3.8.2 A csontmintákból történő DNS izolálás folyamata ............................ 60

3.8.3 A baktérium DNS amplifikálás folyamata........................................ 64

3.9 Egyéb DNS-alapú vizsgálati módszerek - Spoligotyping ................... 65

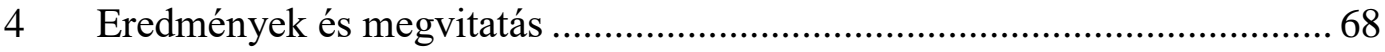

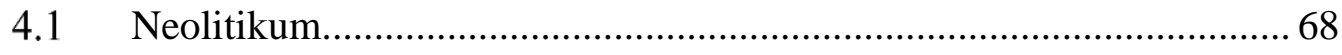

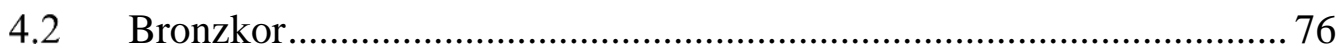

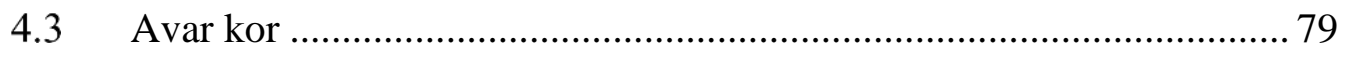

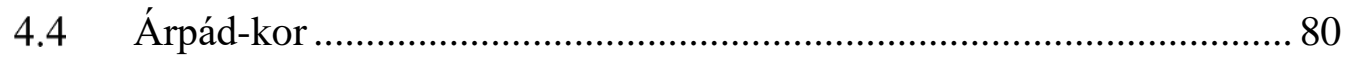

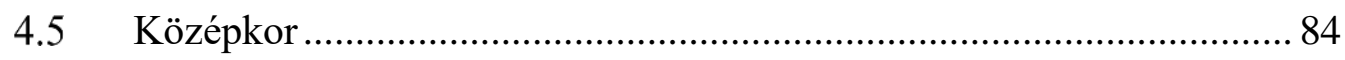

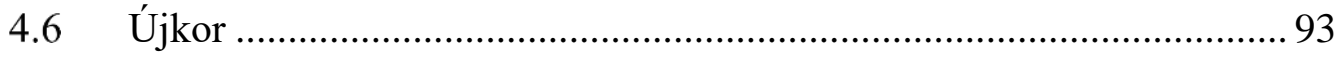




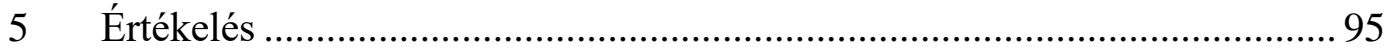

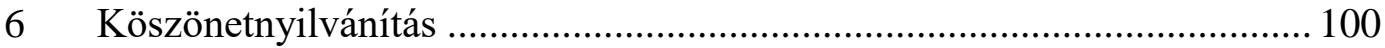

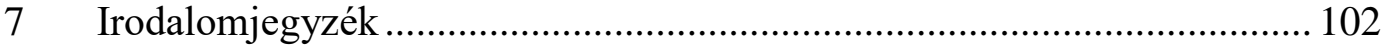

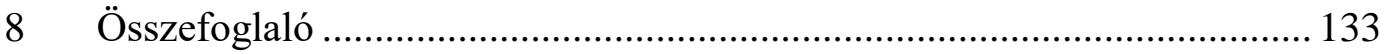

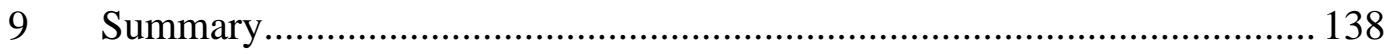

10 A dolgozat alapjául szolgáló publikációk............................................... 144

11 A dolgozat témájához kapcsolódó egyéb publikációk ............................. 144 


\section{Rövidítések jegyzéke*:}

Acquired Immune Deficiency Syndrome - AIDS

archaikus DNS - aDNS

Bacillus Calmette-Guerin vaccine - BCG védőoltás

bázispár - bp

bidesztillált víz $-\mathrm{ddH}_{2} \mathrm{O}$

Bovine Serum Albumin - BSA

citozin $-\mathrm{C}$

computer tomográfia - CT

dezoxynukleotid-trifoszfátot $-\mathrm{dNTP}$

dezoxyribonukleáz - DNáz

dezoxyribonukleinsav - DNS

didezoxynukleotid-trifoszfátot - ddNTP

direkt repeat $-\mathrm{DR}$

Emberi Errőforrások Minisztériuma Egészségügyért Felelős Államtitkársága EMMI EFÁ

etanol - EtOH

etilén-diamid-tetraecetsav - EDTA

extensively drug-resistant, kiterjedten drogrezisztens - XDR

Guanidinium tiocianát - GuSCN

guanin $-\mathrm{G}$

heat shock protein, hősokk fehérjék - hsp (hsp65)

hidrogén-klorid - $\mathrm{HCl}$

* A latin elnevezéseket egységesen, dőltre szedetten tüntettem fel a disszertációmban. 
High Performance Liquid Chromatography, High Pressure Liquid Chromatography, magas teljesítményü folyadék kromatográfia - HPLC

Humán Immundeficiencia Vírusa - HIV

inszerciós szekvencia - IS

isoniacidra - INH

kálium-klorid - $\mathrm{KCl}$

lipoarabinomannan - LAM

magnézium-klorid - $\mathrm{MgCl}_{2}$

multidrug-resistant, multirog rezisztens - MDR

Mycobacteria Other Than Tuberculosis, nem tuberkuloid Mycobacterium (Nontuberculous Mycobacterium) - MOTT, NTM

Mycobacterium bovis - M. bovis

Mycobacterium tuberculosis - M. tuberculosis

Mycobacterium tuberculosis komplex - MTBC

nátrium-acetát - Na-acetát

nátrium-hidroxid - $\mathrm{NaOH}$

nátrium-klorid $-\mathrm{NaCl}$

Next-generation sequencing -NGS

Polymerase Chain Reaction, polimeráz lánc-reakció - PCR

ribonukleáz - RNáz

rifampicinre - RMP

szilícium-dioxid - $\mathrm{SiO}_{2}$

Tris-EDTA - TE

Tris-hidrogén-klorid- Tris/HCl

Trisz-(hidroximetil)-amino-metán - Tris

tuberkulózis - tbc 
ultraibolya, ultraviola sugárzás - UV

Whole Genome Sequencing - WGS

World Health Organization - WHO

Ziehl-Neelsen festés - ZN festés 


\section{Bevezetés}

\subsection{A tuberkulózis epidemiológiája és paleoepidemiológiája}

A humán tuberkulózis az ember egyik legrégebben ismert fertőző megbetegedése (Ortner, 2003; Gutierrez et al, 2005; Hershkovitz et al, 2008; Donoghue, 2009; Baker et al, 2015; Donoghue et al, 2015; Pálfi et al, 2015), ugyanakkor a megbetegedések száma napjainkban is nagy méreteket ölt (WHO, 2016). A tuberkulózis pandémiás megjelenésű, a WHO becslései szerint jelenleg a Föld népességének mintegy 30\%-a látens Mycobacterium tuberculosis hordozó lehet. Emiatt, és a tényleges megbetegedések, ill. a halálesetek magas száma miatt a tbc kutatás rendkívül nagy jelentőséggel bír. A látens kolonizáltak magas aránya azt jelenti, hogy globális szinten nagyon sok egyén él mycobacteriumokkal a szervezetében anélkül, hogy kifejezett, jellegzetes tünetet is mutatna. Korunkban a Mycobacterium tuberculosis a fertözött egyének esetében általában maximum 10\%-nál okozhat aktív betegséget, főként azoknál, akik alacsony szintű immunitással rendelkeznek (gyermekek, idősek, egyéb betegség által legyengült immunrendszerü, ill. alultáplált emberek). A legérintettebbek az AIDS betegek és a hajléktalanok, utóbbiak a társadalom peremén élö emberek, akiknek nincs lehetőségük a betegség kezelésére (Smith, 2003, Figueroa-Munoz és Ramon-Pardo, 2008). A WHO 2016-os tbc-jelentése alapján 2015-ben 10,4 millió volt a bejelentett új tbc-s esetek száma világszerte (1. ábra), ebből 5,9 millió férfi, 3,5 millió nő és 1 millió gyermek, közülük 480.000-en multidrog rezisztens mycobacteriumokkal fertőzöttek (MDR) $)^{\dagger}$.

$†$ A multirog rezisztens mycobacteriumok esetében rezisztencia áll fent isoniacidra (INH) és rifampicinre (RMP). Még nagyobb problémát jelent, hogy a kiterjedten drogrezisztens (XDR) tuberkulózis esetében rezisztencia áll fent isoniacidra és rifampicinre, továbbá bármely fluorokinolonra és másod vonalbeli szerre (pl.: amikacin, kanamycin, vagy capreomycin) is. 


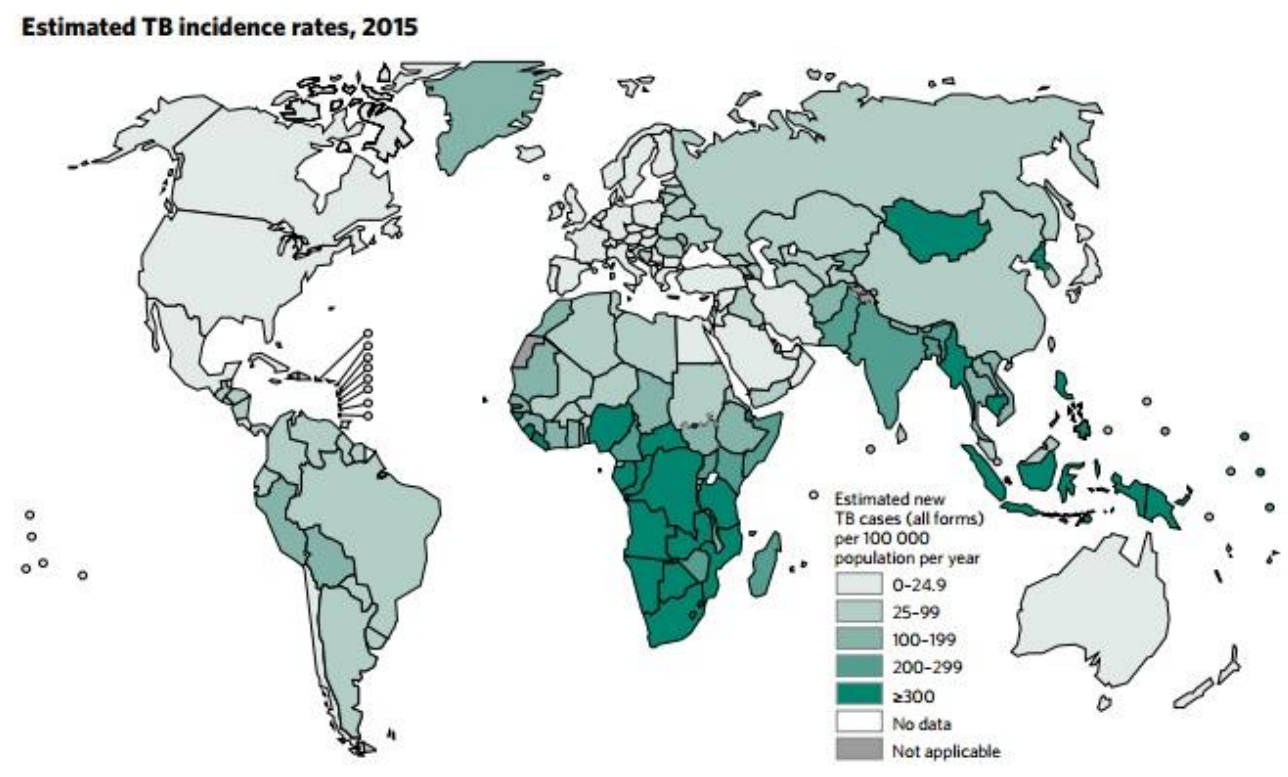

1. ábra: A tbc becsült incidencia térképe 2015-ben a WHO felmérései szerint (http://www.who.int/tb/publications/global_report/en/).

A 2015-ös adatok alapján tudjuk, hogy abban az évben 1,8 millió beteg halálozott el tbc-ben világszerte. Közöttük még mindig magas számban, összesen 0,4 millió esetben fordult elő Mycobacterium okozta haláleset HIV fertőzöttek körében, ez a tendencia enyhe csökkenést mutat az előző évekhez képest, de ma is aggasztóan magas érték (WHO, 2016). Az adatokat valamelyest javítja az a tény, hogy a fejlett világ országaiban kezelik az AIDS-betegeket, de pl.: Fekete-Afrika területén ma is nagyon súlyos a helyzet (2. ábra). A HIV fertőzöttek esetében 21-34-szer nagyobb a kockázata annak, hogy az egyén Mycobacterium sp.-vel fertőződik, mint a HIV fertőzésmentes társaiknak. Az újonnan regisztrált tbc-s betegek 11\%-a, azaz 1,2 millió ember HIV fertőzött (WHO, 2016). A HIV-vel fertőzöttek körében gyakran a Mycobacterium avium és a Mycobacterium kansasii okoz granulómás fertőzést (pl.: tüdő, vese, agy), a legyengült immunrendszerük miatt, ezt atipikus fertőzésnek nevezik (Johnson és Odell, 2014). 

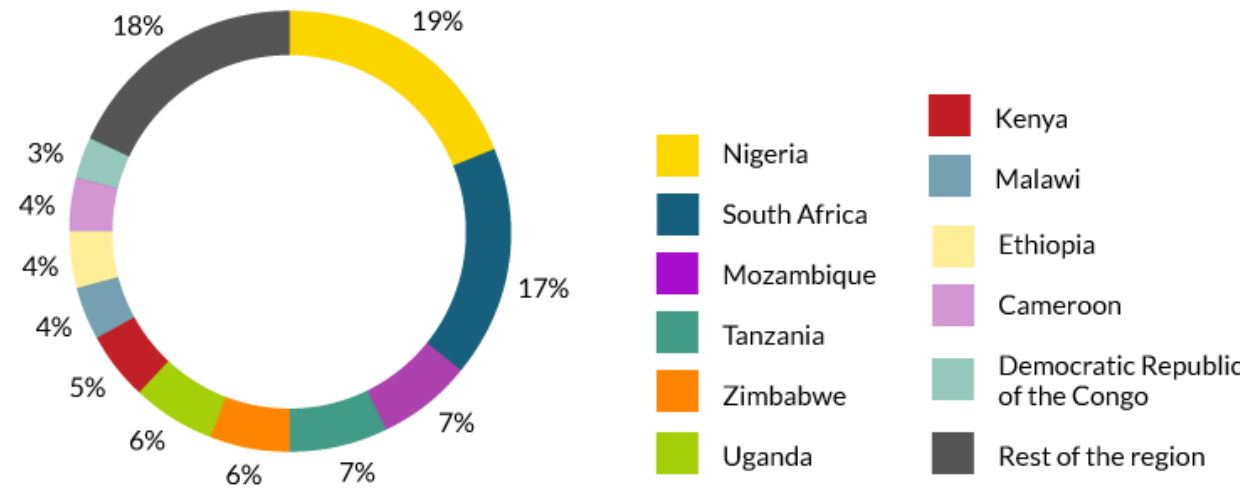

2. ábra: Az AIDS-vel összefüggésbe hozható elhalálozások aránya Fekete-Afrika területén 2013ban (http://www.avert.org/professionals/hiv-around-world/sub-saharan-africa/overview).

A magyarországi Emberi Errőforrások Minisztériuma Egészségügyért Felelős Államtitkársága (EMMI EFÁ, korábban Egészségügyi Minisztérium) szakmai összefoglalója egyéb hajlamosító tényezőket is jegyez a betegség kialakulására. Ilyen tényezők: alkoholfüggőség, kábítószerfüggőség vagy fogyasztás, ill. számos betegség következtében is kialalkulhat a tbc: diabetes mellitus, silicosis, a fej és a nyaki régió malignus betegsége, hematológiai megbetegedések, zsugorvese, gastrectomia utáni állapot, krónikus malabszorpciós-szindróma, leromlott általános állapot vagy intesztinális bypass, szervtranszplantáció utáni állapot, kortikoszteroid- vagy immunoszuppreszív kezelés. Továbbá bizonyítottá vált, hogy a betegségre való hajlam mögött genetikai háttér is megfigyelhető, egyes színesbőrü népcsoportok, mint az eszkimók, negridek, ill. filippinók nagyobb gyakorisággal fertőződnek meg, mint fehérbőrü társaik (Tüdőgyógyászati Szakmai Kollégium: Az Egészségügyi Minisztérium szakmai protokollja a Tuberkulózisról (1. módosított változat) 2011; Az Emberi Erőforrások Minisztériuma Egészségügyért Felelős Államtitkárságának egészségügyi szakmai irányelve a tuberkulózis prevenciójáról, diagnosztikájáról, terápiájáról és gondozásáról 2015).

Hazánkban a tuberkulózis régen népbetegségnek számított. A XIX-XX. század fordulóján, majd a XX. század első felében morbus hungaricus-nak is nevezték a betegséget. Győry Tibor monográfiája alapján tudjuk, hogy a morbus hungaricus 
kifejezést, melyet ma is a tbc szinonímájaként használunk, a XVI-XVIII. század között még egy másik betegség, a kiütéses tífusz megnevezésére használták (Győry, Morbus hungaricus, 1900). Orvostörténeti források szerint a betegség a XIX. század során fokozatosan egyre több ember betegségét/halálát okozta hazánkban. Magyarországon az újkori városiasodással lobbant fel a tbc, és a XIX. század utolsó évtizedeiben már népbetegségnek számított. Kapronczay tanulmányai szerint statisztikailag az 1850-es évektől lehet nyomon követni. Az első hiteles pesti statisztika szerint 1849-ben Pesten 700 tbc-haláleset fordult elö, ez megközelítőleg az összlakosság halandóságának 12,5\%a volt. 1883-ban már a teljes halandóság 25\%-át kitevő 3182 gümőkóros haláleset fordult elő (Budapesten). Korányi Frigyes szerint Magyarországon 1894-ben már összesen 66 ezren haltak meg tbc-ben, a tuberkulózisban megbetegedettek számát 400 ezerre becsülték. Egyes budapesti peremkerületekben a lakosság 45\%-a volt tbcmegbetegedett. Ezekben az években ragadt rá a morbus hungaricus elnevezés a betegségre, és ekkor javasolták, hogy a szegény sorsú tbc-sekről az állam gondoskodjon, ill. megfelelő szanatóriumokat és gyógykezelő hálózatot építsenek ki. A Czigler Győző által tervezett Erzsébet Királyné Szanatórium (ma: Országos Korányi Tbc és Pulmonológiai Intézet) 1901-ben nyitotta meg kapuit (Kapronczay, 2010).

A magyarországi tbc megbetegedések aránya még a II. világháború utáni időszakban is jelentős volt, javulás csak a hatásos gyógyszerek és a betegség ellen irányuló intézményrendszerek megjelenését követően volt megfigyelhető. A 2015-ös évi magyarországi adatok 905 bejelentett új esetet tartottak számon, ahol bakterilógiailag 402 esetben igazolták a fertőzést (Korányi Bulletin, 2016). A fent említett adatok esetében a betegek kétharmada férfi, egyharmada nő volt, és 94\%-ban tüdőtuberkulózis volt megállapítható, a csonttuberkulózis jelenléte elenyésző volt a betegek között. Magyarországra is jellemző, hogy az 1953-ban bevezetett, és kötelezően beadandó újszülöttkori BCG oltásnak köszönhetően a gyermekek között rendkívüli mértékben lecsökkent a megbetegedések száma. A betegség megjelenése férfiak esetében a 30 és 59 éves kor közötti korcsoportra jellemző, míg nőknél inkább a kor elörehaladtával figyelhető meg (Tüdőgyógyászati Szakmai Kollégium: Az Egészségügyi Minisztérium szakmai protokollja a Tuberkulózisról (1. módosított változat) 2011; Az Emberi Erőforrások Minisztériuma Egészségügyért Felelős 
Államtitkárságának egészségügyi szakmai irányelve a tuberkulózis prevenciójáról, diagnosztikájáról, terápiájáról és gondozásáról 2015). Dr Szarka Ildikó pulmonológus, gondozóvezető főorvos szóbeli közlése alapján a magyarországi tbc megbetegedések száma jelentősen csökkent az elmúlt évek során (3. ábra). Ezt a WHO adatai is alátámasztják.

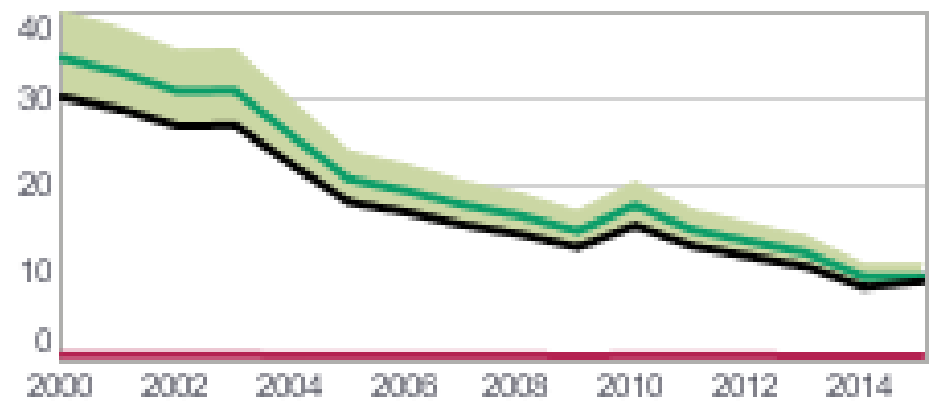

\section{3. ábra: A tbc előfordulási rátája Magyarországon 100.000 főre vetítve} (http://www.who.int/tb/publications/global_report/en/).

Napjainkban a legfontosabb, tuberkulózis kialakulásáért felelős speciesek: a Mycobacterium tuberculosis, ill. a Mycobacterium bovis, Mycobacterium africanum és a Mycobacterium canetti. Ezek mellett a föként állatokat fertőző fajok - Mycobacterium microti (pocok, cickány), Mycobacterium caprae (kecske, szarvas) és Mycobacterium pinnipedii (fóka) - is a Mycobacterium tuberculosis komplex tagjai közé tartoznak, mivel kisebb gyakorisággal emberben is kiválthatnak gümőkóros megbetegedést (Brosch et al, 2002; Smith, 2006; Gordon és Behr, 2015). Számos Mycobacterium sp. fordul elő a környezetünkben, de a Mycobacterium tuberculosis komplex tagjai között található a legtöbb aerob, obligát patogén (Brites et al, 2015; Domogalla et al, 2013; Donoghue, 2008; Holloway et al, 2011; Mándi, 2013; Müller et al, 2014). Az aktív tüdő-tbc talaján a megbetegedettek 3-5\%-nál fejlödhet ki csonttuberkulózis, amely látható nyomot hagy a csontokon is. A modern medicinában a csont-ízületi tbc egy a gümőkór nagyszámú típusa/lokalizációja közül, a paleopatológia számára azonban hatványozott jelentőséggel bír. Általában a viszonylag specifikusnak mondható vázrendszeri tbc-tünetek alapján ismerhetjük fel a betegség múltbeli előfordulását, és becsülhetjük meg a tbc pusztításának arányait a régi emberi közösségekben. Mindehhez a régi csontvázmaradványok alapos, morfológiai tanulmányozása szükséges (melyekröl 
a dolgozat későbbi, paleopatológiai vonatkozású fejezeteiben, illetve néhány esettanulmány kapcsán további információkkal is szolgálunk). Néhány betegség azonban a tbc-hez hasonló elváltozást okozhat a vázrendszeren, ilyen pl. a „morfológiai mimikriként" ismert brucellózis, de olykor traumás elváltozások (különösen poszttraumás infekcióval párosulva), ill. más fertőző betegségek is hasonló csonttani tüneteket okozhatnak (Resnick és Niwayama, 1995; Ortner, 1999, 2003). На a morfológiai elváltozások nem egyértelmủek, vagy nem láthatók, paleopatológiai vizsgálatok esetében a DNS vizsgálatok igazolhatják a fertőzöttséget (Zink et al, 2001; Donoghue et al, 2005; Raff et al, 2006; Donoghue, 2009; Nerlich et al, 2009). Ez indokolja az ún. paleomikrobiológiai kutatások alkalmazását, további fejlesztését (Donoghue, 2008).

Alapos ismeretek szükségesek a tbc paleoepidemiológiájáról, azaz a gümőkóros megbetegedés és az annak hátterében álló mycobacteriális fertőzés(ek) múltbeli gyakoriságáról és egyéb járványtani jellemzőiről, továbbá a fertőző ágens(ek) evolúciós potenciáljáról, annak érdekében, hogy a már meglévő ismereteinkre építkezve, további kutatások segítségével, közvetve a kór megfékezéséhez is hozzájárulhassunk. Az emberiség még több információt nyerhet, ha a komplex kutatások a betegség történetének korábbi időszakaira is megfelelően fókuszálnak. Ezekről a korszakokról a hagyományos paleopatológiai és a paleomikrobiológiai vizsgálatok együttesen adhatnak bővebb információt az ásatag vagy mumifikálódott humán maradványok vizsgálatával. Az archaikus DNS-sel folytatott molekuláris biológiai kutatások hozzájárulnak ahhoz, hogy jobban megérthessük a patogének evolúcióját is (Pálfi et al, 1999, 2015).

\subsection{A Mycobacterium tuberculosis komplex jellemzöi}

A gümőkórt okozó baktériumot 1882-ben Robert Koch ${ }^{*}$ német orvosmikrobiológus írta le, így Koch-bacillus néven is ismert. Kis pálcika alakú (2-4 $\mu \mathrm{m}$

* Koch a felfedezéséért 1905-ben Nobel-díjat kapott. A felfedezés 1882. március 24-i dátumának emlékére március 24. a tbc elleni küzdelem világnapja. 
hosszú és 0,2-0,5 $\mu \mathrm{m}$ széles), obligát, aerob baktérium, mely rendkívül lassan osztódik és kizárólag a gazdában képes szaporodni (4. ábra).

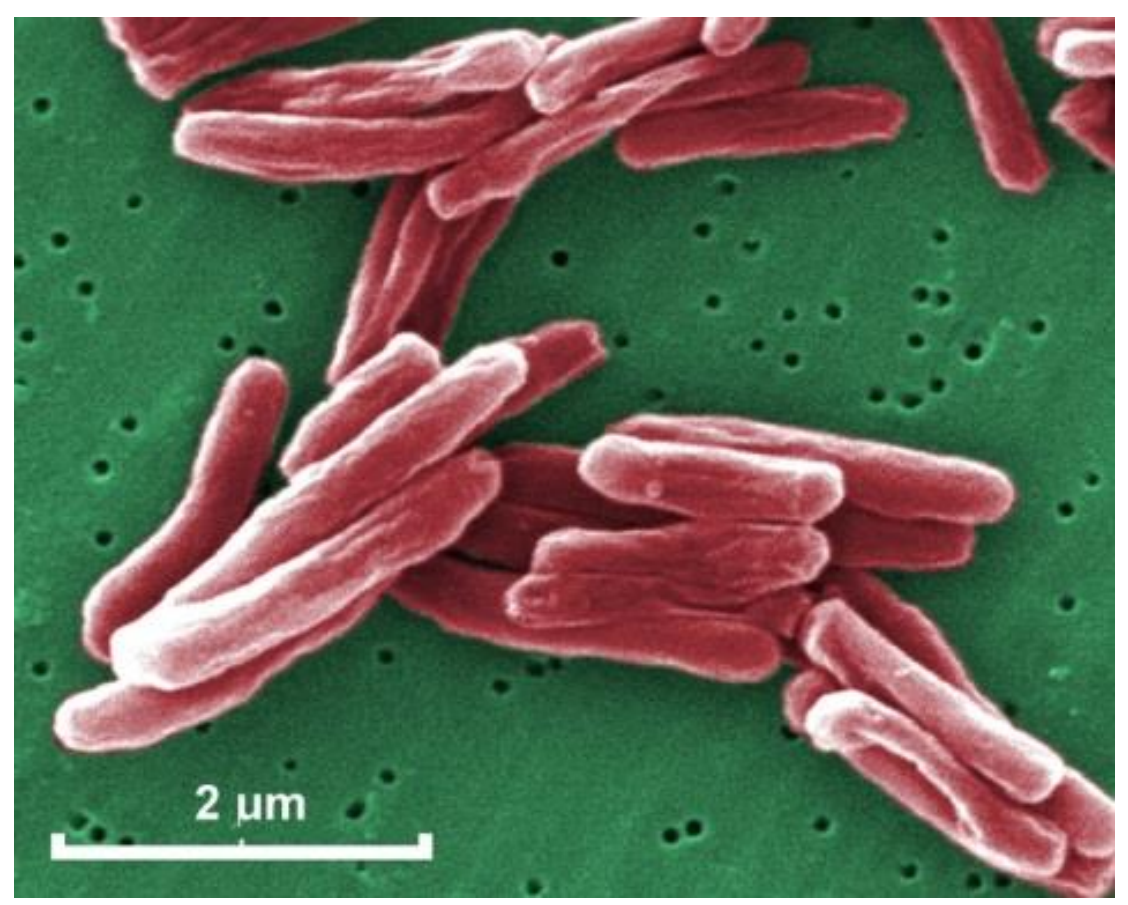

4. ábra: Mycobacterium tuberculosis 15549-szeres szkenning-elektronmikroszkópos, színezett képe

(http://www.microbiologyinpictures.com/bacteria\%20photos/mycobacterium\%20tuberculosis\% 20photos/MYTU20.html).

A Mycobacterium tuberculosis komplexbe (Mycobacterium tuberculosis, Mycobacterium bovis, Mycobacterium africanum, Mycobacterium canetti, Mycobacterium microti, Mycobacterium caprae és Mycobacterium pinnipedii) sorolt, egymással közeli rokon baktériumfajok/alfajok felelősek az emberben és más emlösökben kialakuló tbc betegségért. A további lehetséges humánpatogén mycobacteriumokat Mycobacteria Other Than Tuberculosis (MOTT), vagy régebbi nevükön atípusos, nem tuberkuloid Mycobacterium-ként (NTM) csoportosítjuk. A Mycobacterium tuberculosis komplex többi tagjához hasonlóan a $M$. tuberculosis számos fertőtlenítőszernek ellenáll, spórát, tokot nem képez, alapvetően Grampozitív sejtfallal rendelkezik (bár, Gram szerint nem besorolható), külső membránnal nem, komplex sejtfallal (5. ábra) viszont rendelkező baktérium (Ryan és Ray, 2004; Mándi, 2013). 


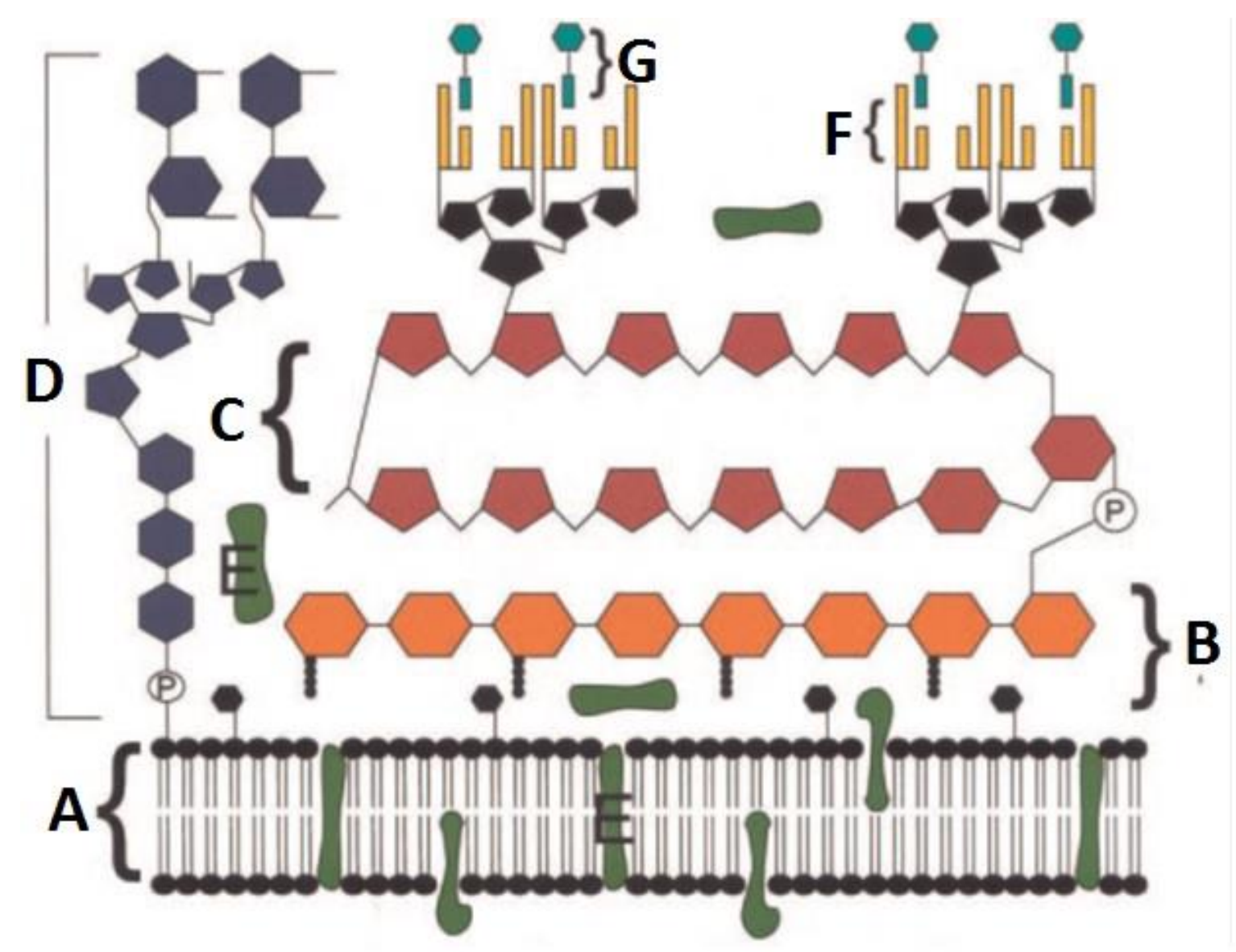

5. ábra: Mycobacterium tuberculosis sejtfalának felépítése (az ábrán található jelölések magyarázatra a szövegben) (Karakousis et al, 2004).

A kórokozó sejtfalának fő alkotóeleme a lipoarabinomannán (LAM) (5. ábra D), amely hasonló a Gram-negatív baktériumok lipopoliszacharid rétegéhez. A palzamembránon (5. ábra A) helyezkedik el a peptidoglikán (5. ábra B), ehhez a réteghez kapcsolódnak az elágazódó arabinogalaktán molekulák (5. ábra C). Ezekhez kapcsolódik észter kötéssel a nagymolekula tömegü hidrofób mykolsav (5. ábra F), a nagy szénatomszámú molekulákhoz pedig a felszíni glikolipid molekulák (5. ábra G) kötnek. Ezen kívül számos fehérje (5. ábra E) kötődik a plazmamebránba merülve, ill. a felszínéhez kötötten. A Mycobacterium sejtfalának szerkezetéből következik azon tulajdonsága, hogy a jelenlévő lipidekben gazdag sejtfala miatt felszíne hidrofób, ill. rendkívül ellenálló a savnak és az alkoholnak. A festődésének (Ziehl-Neelsen festés) menete is ezzel függ össze, hiszen a festékek is nagyon nehezen diffundálnak át a 
szerkezetén, így ha egyszer bejutottak, akkor a sav vagy alkohol sem képes kimosni öket onnan (Karakousis et al, 2004).

A tuberkulózis-fertőzés patogenezisét tekintve a kórokozó cseppfertőzés útján kerül a tüdőbe, ahol az alveoláris makrofágok bekebelezik. A M. tuberculosis virulenciájáért jelentős mértékben sejtfal-komponensei felelösek (Daffé et al, 2015). Az emlősökben a vastag sejtfalának köszönhetően él túl és képes szaporodni, kikerülve a gazda immunrendszerét. A baktériumok gátolják a fagolizoszóma kialakulását és közben intracellulárisan a makrofágokban szaporodnak. A kórokozók által fertőzött makrofágok elpusztulnak, majd a mikróbák kiszabadulnak és újabb makrofágokat fertőznek meg, ezzel felforgatva a sejt-mediált immunválaszt. Tehát a fertőzés terjedése a makrofágok közvetítésével történik, a baktériumok eljutnak a perifériás nyirokcsomókba, majd a véráram által más szervekbe pl.: csontvelöbe, lépbe, vesébe, csontokba és központi idegrendszerbe is (Ryan és Ray, 2004).

\subsection{A Mycobacterium tuberculosis evolúciója}

Cole és munkatársainak köszönhetöen a $M$. tuberculosis legjobban ismert, laboratóriumi kutatásokra használt ún. $\mathrm{H}_{37} \mathrm{Rv}$ törzsének genomja 1998 óta ismert, és azt is tudjuk, hogy az 4.411 .529 bp és 4000 génböl áll (Cole et al, 1998). A genetikai és a paleopatológiai tudományterületeken dolgozó kutatók sokáig úgy tartották, hogy a $M$. tuberculosis a Mycobacterium bovis-ból alakult ki， a szarvasmarhafélék domesztikációját követően, ill. annak következtében, s fertőzte meg fokozatosan a későbbi emberi populációkat (pl.: Cockburn, 1963; Ortner, 1999). Ez a hipotézis egészen a kétezres évek elejéig tartotta magát, ekkor azonban a molekuláris genetikai kutatások eredményei több tanulmányban is rávilágítottak arra, hogy a Mycobacterium tuberculosis ősibb faj, mint a M. bovis (pl.: Brosch, 2002; Filliol et al, 2006; Hershberg et al, 2008), így a gümőkóros megbetegedés elsődleges kórokozója nem a szarvasmarha-félék háziasítása során, ill. következtében került a humán gazdaszervezetbe. Egy 2008-as komplex paleopatológiai-paleomikrobiológiai tanulmány a Közel-Keletröl származó (Atlit Yam, Izrael), mintegy 9000 éves humán leletek elemzésén keresztül igazolja a betegség korai előfordulását, és rávilágít arra, 
hogy a fertőző ágens már jelen volt a szarvasmarha háziasítása idején is (Hershkovitz et al, 2008). Ugyan az Atlit Yam-i 9 évezredes tbc rendkívül régi, azonban mégsem cáfolja még egyértelműen az említett „domesztikációs elméletet”. A közelmúltban felfedezett szíriai (Dja’de el Mughara lelőhelyről származó), több mint tízezer éves paleopatológiai tuberkulózisos esetnél azonban a kormeghatározás és az archeológiai/archeozoológiai kontextus egyértelmüen domesztikáció előtti fertőzést jeleznek (Dutour et al, 2010; Baker et al, 2015). A disszertációmban leírt, magyarországi neolitikum korszakából származó két temető a fentebb megfogalmazottak miatt is nagy jelentőséggel bír, mivel igazolni tudtuk a megbetegedés ill. fertőzöttség előfordulását a két lelőhelyen eltemetett neolit kori népességben.

Tudjuk, hogy tuberkulózis állat-, vagy ember által közvetített formában terjed. Az is valószínüsíthető, hogy a Mycobacterium tuberculosis komplex tagjai egy közös őstől (6. ábra), az egyes szerzők által Mycobacterium prototuberculosis-nak nevezett formából származhatnak (Brosch et al, 2002; Weber doktori disszertáció, 2013), amely sok szerző szerint együtt evolválódhatott az emberiséggel (Camus et al, 2002; Gutierrez et al, 2005; Brisse et al, 2006; Wirth et al, 2008; Weber doktori disszertáció, 2013; Comas et al, 2013; Bos et al, 2014; Boritsch et al, 2014, Donoghue, 2017). A közös-ös teóriájának relevanciáját az sem befolyásolja, ha az utóbbi időben vita bontakozott ki a M. tuberculosis megjelenésének konkrét idejéről (pl.: Comas et al, 2013; Bos et al, 2014). 


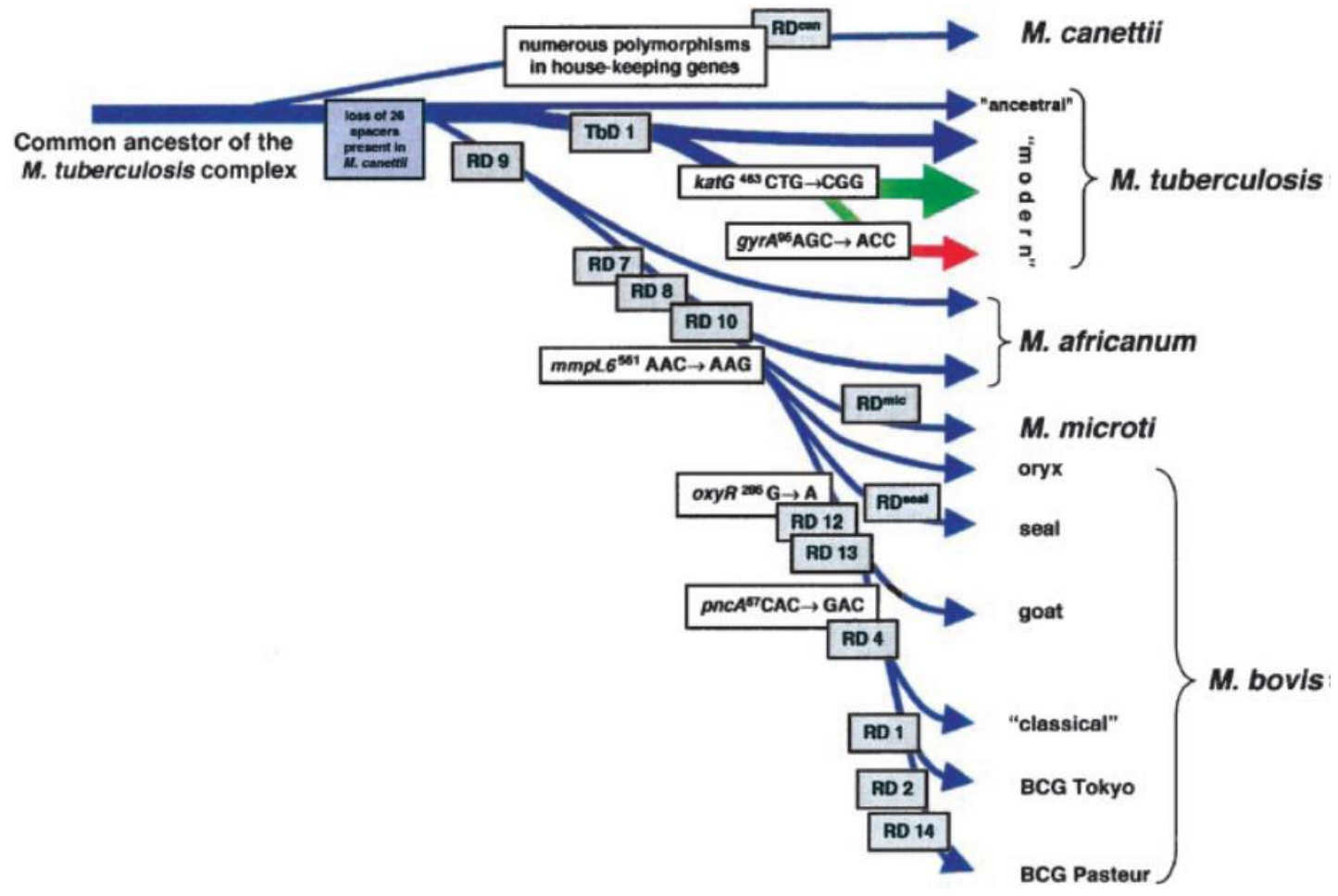

6. ábra: A Mycobacterium tuberculosis komplex egyes tagjainak törzsfejlődési útvonala

(Brosch et al, 2002).

\subsection{A paleopatológiai diagnosztikai módszerek}

A tuberkulózis kialakulásáért felelős baktérium az ember összes szervrendszerében okozhat elváltozásokat. A betegség legáltalánosabb megjelenési formája a tüdő-tbc, de olykor a csontokon is megfigyelhető a kórokozó által kifejtett hatás, bár ezek az elváltozások, klasszikus formájukban, általában csak a betegség későbbi szakaszában alakulnak ki (Ortner, 2003). A csontok fertőződése a vér és a nyirokrendszer útján, ritkábban direkt módon történik.

A történeti korú csontok vizsgálatánál gyakorta előfordul, hogy a paleopatológus nem tapasztal tbc-re utaló csonttani tüneteket, mivel az egyén a betegség korai fázisában halálozott el és a csonttünetek kifejlődésére már nem kerülhetett sor. A régebbi paleopatológiai tanulmányok általában a krónikus tbc-s csigolyagyulladást (spondylitis tuberculosa) a tipikus megjelenésű ún. Pott-gibbus néven ismert, a csigolyák összeroppanását okozó elváltozást ismertették. (Ilyen összecsontosodott Pott-féle 
gerinc-elváltozás képét mutatja a 13. és 19. ábra, neolitikumból, ill. az Árpád-korból származó csontminták esetén).

A csonttuberkulózis a hosszú csöves csontok esetén általában az epiphysis-ek körül alakul ki, a betegség átterjedhet az ízületekre is, továbbá a bordákon, a tüdőről a mellhártyán keresztüli direkt ráterjedéssel, a csonthártyán át a borda zsigeri felszínére, olykor akár több egymás melletti borda fertőződését és elváltozásait is kiváltva.

A paleopatológiában a krónikus spondylitis tuberculosa mellett „klasszikus”, vagy „tipikus” elváltozásnak tekintik a tbc-s ízületi gyulladásokat (arthritis tuberculosa) is, amelyek elsősorban a nagyízületek (pl.: csípő-, térd-, váll-, vagy a könyökízület - 24. ábra) csontos ízfelszínein és környékén diagnosztikai értékü súlyos károsodáshoz, esetleg összecsontosodáshoz (ankylosis) vezethetnek (Pálfi et al, 1999; Ortner, 2003). A kórfolyamat során az ízületi porcok elpusztulnak, és a betegség átterjedhet az ízületi üregre. Az ízületekben gennyesedés alakul ki, melynek következtében az ízületi tok áttörhet, összezsugorodhat, megindulhat a hegesedés az ízületi üregben - azaz kialakulhat a fentebb már említett ankylosis, tehát a két csontvég összecsontosodhat, ezáltal megszünhet az ízületi összeköttetés, és a két csont rögzülhet egymáshoz.

A paleopatológiai vizsgálatok során gyakran találkozunk a betegség ún. „atípusos” csontelváltozásaival is. Atípusos tbc-s csontelváltozásnak tekinthetők pl.: a bordák belső felszínén megfigyelhető csonthártya-gyulladás (periostitis) nyomok vagy egyéb gyulladásos eredetű csontelváltozás (osteitis) nyomai, amelyek leggyakrabban tüdő-, ill. mellhártya-tbc következtében alakulnak ki (pl.: Roberts et al, 1994; Pálfi, 2002).

Atípusos csontelváltozások közé szokás besorolni a tbc-s agyhártyagyulladás (meningitis basilaris tuberculosa) okozta endocranialis elváltozásokat is, melyekkel a paleopatológus föként gyermek-vázakon találkozik, idősebb egyének koponyáin valamivel ritkábban figyelhetők meg. Nagyon jól prezentálja ezt a Bácsalmás-Óalmáson feltárt rác temető leletegyüttese, ahol a lehetséges tbc fertőzöttekből a gyermekek aránya 62,9\%, közöttük sok esetben valószínü tbc-s meningitis tüneteivel (Lovász, 2015). Az elváltozást a koponyatető belső felszínein megjelenő abnormális gödörkézettség, rendellenes érbenyomatok és vékony felszíni újcsont-felrakódások 
formájában ismerhetjük fel (Schultz, 1999; Hershkovitz et al, 2002; Pálfi et al, 2012) (23. ábra).

A lehetséges atípusos tbc-s csontelváltozások közé soroljuk még a leginkább a hosszúcsontokon megjelenő diffúz (sok csontot érintő) gyulladásos nyomokat, illetve a csigolyatestek gyulladásos eredetü hypervascularisatio-ját, vagy a csak felszíni csontátépüléssel járó atípusos csigolyatest-gyulladásokat (Baker, 1999; Pálfi, 2002; Maczel, 2003). Továbbá tbc-re jellemző potenciális „stressz-indikátor” még a csontos szemüreg felső lemezén, vagy a koponyatető területén, a kompakt csontszövet helyén másodlagosan megjelenő szivacsos csontállomány kialakulása (cribra orbitalia és cribra cranii) - amelyek gyakran jelennek meg más tbc-s csonttünetekkel együtt, különösen fiatal egyének csontvázain.

A humán paleopatológia makroszkópos morfológiai vizsgálatok segítségével melyet olykor radiológiai vagy mikroszkópos technikák is kiegészítenek - legalább egy évszázada tanulmányozza a tbc megjelenését régi emberi maradványokon (Pálfi et al, 1999; Ortner, 2003). A morfológiai elváltozások azonban nem mindig tekinthetők diagnosztikus érvényűnek (ill. önmagukban nem mindig elég „specifikusak”), ezért a paleopatológiai kutatásokban fokozatosan alkalmazni kezdték az archeogenetikai/paleomikrobiológiai eljárásokat is. 


\subsection{Az archeogenetika kialakulása és a molekuláris biológián alapuló archaikus tbc kutatás tudománytörténeti összefoglalása}

1984-ben az elsők között Russell Higuchi és munkacsoportja egy múzeumban kiállított quagga példány - a lófélék családjának egy ága (a faj véglegesen 1883-ban halt ki) - 140 éves kiszáradt izomzatából DNS-t izolált. Hagyományos szekvenálás során, két klón alapján egy 229 bp-os mitokondriális DNS szakasz nukleotidsorrendjét határozták meg. E szakaszon 12 nulkeotidban tért el a hegyi zebra szekvenciájától, így sikerült besorolni a quaggát a lófélék családjának törzsfáján (Higuchi et al, 1984). Ezt követően az uppsalai egyetem fiatal PhD hallgatója, Svante Pääbo 1985-ben egy 2400 éves gyermekmúmia bőréből sikeresen klónozott, majd ezt követően szekvenált egy közel 500 bp-os DNS szakaszt (Pääbo, 1984; Pääbo, 1985).

A genetikai vizsgálatokban hatalmas áttörést jelentett az 1983-ban Kary Banks Mullis által felfedezett új technika, a polimeráz lánc-reakció (PCR) (Mullis et al, 1986, 1987), melyet azóta rutineljárásként minden molekuláris biológiai labor alkalmaz. A technika alapja egy primer pár által kijelölt génszakasz amplifikálása hozzáadott nukeotidok beépítésével, melyet egy hőstabil enzim végez el, amit a Yellowstone Park forrásvizéből izolált Thermus aquaticus-ból állítanak elő, ez a Taq polimeráz. Hamarosan az archaikus DNS kutatások esetében is bevezették a módszert, és 1988-ban Pääbo és munkatársai elsőként alkalmazták a PCR-t egy 7000 éves egyiptomi múmia agyából izolált DNS-en (Pääbo et al, 1988). Nem minden esetben áll rendelkezésre azonban mumifikálódott lágyszövet, így 1989-ben Bryan Sykes és csoportja elsőként izolált emberi csontmaradványokból archaikus DNS-t (Hagelberg et al, 1989). Ezt követően számos kihalt faj esetében sikerült DNS-t azonosítani múzeumi maradványokból, így 1989-ben az erszényes farkasnál (Thylacinus cynocephalus), 1992-ben a moa (Dinornis robustus) esetében, ill. a mamutnál (Mammuthus primigenus) (Thomas et al, 1989; Cooper et al, 1992; Hagelberg et al, 1994; Krause et al, 2006). 
Ezzel párhuzamosan a molekuláris tuberkulózis-kutatás dinamikusan fejlődött klinikai, recens mintákon, hiszen a tbc-megbetegedés napjainkban is világméretü problémát jelent. Thierry és munkatársai 1990-ben publikálták, hogy az ún. IS6110 inszerciós szekvenciát (7. ábra), melyet a Mycobacterium tuberculosis komplex minden tagjának genomja tartalmazza (Thierry et al, 1990). Az inszerciós szekvencia egy transzpozábilis elem, mely az IS3 család tagja és 1361 bp-ból áll, mindkét végén egyegy 28 bp-os inverted repeat-et tartalmaz (Fang et al, 2001). Az IS6110 sejtenként 1-26 kópiában fordulhat elö, ill. megfelelő primerek alkalmazása esetén 123 bp-os fragmentet ad az amplifikáció során (Salo et al, 1994; Stone et al, 2009; Coscolla et al, 2014).

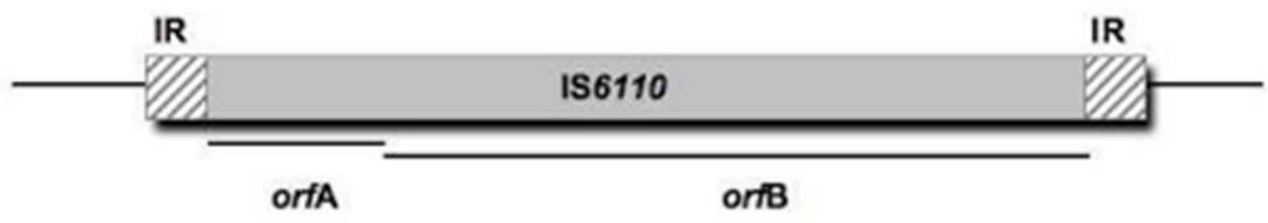

7. ábra: A Mycobacterium tubeculosis IS6110 inszerciós szekvenciája.

Thierry és munkatársai, valamint velük mintegy párhuzamosan, Eisenach és munkacsoportja recens mintákon alkalmazták a Mycobacterium tuberculosis-ra jellemző szekvenciát (IS6110) a tbc PCR-alapú diagnosztikájában (Eisenach et al, 1990, 1991).

1992/93-ban Spigelman és Lemma összegezték az archeogenetika és a molekuláris tbc diagnosztika addigi eredményeit, s kutatásaik során, azokat mintegy ötvözve, útjára indítottak egy teljesen új területet, a paleomikrobiológia tudományát (Spigelman és Lemma, 1993). Tudták, hogy a tuberkulózis jellegzetes elváltozást okozhat a csontokon, azt vizsgálták, hogy vajon molekuláris eszközökkel kimutatható-e a kórokozó DNS-e az archaikus mintákból. Már ismert volt számukra Sykes és csoportja munkásságából, hogy régi emberi csontokból extrahálható az endogén DNS (Hagelberg et al, 1989). Hipotézisük az volt, hogy a megfelelő komplex eljárás alkalmazásával történeti korú egyének csontanyagából a kórokozó-DNS izolálható lehet. Az első primer pár, melyet alkalmaztak, a fentebb említett inszerciós szekvenciát 
célozta meg (MTBC-specifikus lókusz: IS6110), ezt használta Eisenach is 1990-ben recens klinikai mintákon. Mivel a lókusz gyakran prezentálódik több kópiában a baktériumsejtben, ezért preferált diagnosztikai szakasszá vált a tbc vizsgálata során (Eisenach et al, 1990, 1991). Spigelman és kutatócsoportjának 1993-as eredményei (Spigelman és Lemma, 1993) után nem sokkal Salo 1994-ben ugyanazokat a primereket alkalmazva klónozta és szekvenálta az amplikonokat egy 1000 éves perui múmia tüdőszövetéből, ezzel arra is rávilágított, hogy a betegség legalább egy évezrede jelen volt Amerikában, Kolumbusz Kristóf hajóinak megérkezése előtt is (a XIX-XX. századok során többször felmerült, hogy az Újvilágba a gümőkórt a gyarmatosító európaiak hurcolták be). Salo nested PCR-t alkalmaztott az eljárás megerősítéseként, ebben az esetben a reakció 97 bp-os amplikont adott (Salo et al, 1994). Az eljárást Taylor és kutatócsoportja hamarosan középkori mintákon is alkalmazta, de itt más primerekkel, melyek kisebb, 92 bp-os terméket adtak (Taylor et al, 1996). Az első amplifikálás során sok minta adhat 123 bp körüli terméket, de a nested PCR-t követően a legtöbb kiesik (Müller et al, 2015). A nested PCR során a nem kívánt PCR termékek kialakulását előzhetjük meg, a folyamat abból adódhat, hogy az egyik primer aspecifikusan is képes kötődni a célszekvenciához, ezt kiküszöbölendő két PCR reakciót alkalmaznak, ahol a második primer pár templátja az első primer párok által létrehozott amplikon. Napjainkban is ezt a primer párt alkalmazzák polimeráz láncreakció során a baktérium jelenlétének igazolására. Nerlich 1997-ben kevéssé specifikus primereket alkalmazott, ahol 133 bp-os terméket kapott a hsp65 génböl, de később bizonyítást nyert, hogy az IS6110 sokkal specifikusabb (Donoghue, 2008; Rault és Drancourt, 2008; Nerlich et al, 1997, 2009). Helen Donoghue és munkatársai a 2000es évek elejétől párhuzamosan kétféle inszerciós szekvenciát vizsgáltak (IS6110 és IS1081) a nagyobb diagnosztikus biztonság érdekében (Donoghue 2008, 2011; Donoghue et al, 2005, 2015).

\subsection{Az archaikus DNS tulajdonságai}

$\mathrm{Az}$ archaikus DNS-sel történő vizsgálatot több tényezö is nehezíti, melyek az aDNS tulajdonságaiból adódnak, amiket Pääbo tanulmányában összegzett. Rendkívül 
limitált mennyiségben áll a kutatók rendelkezésére, hiszen oxidatív és hidrolitikus bázismódosulásokon megy keresztül a DNS, ebből adódik, hogy erőteljesen fragmentálódik, 60-150 bp hosszúságú szakaszok kimutatása az általános (Pääbo, 1987; Pääbo et al, 1989; Gilbert et al, 2003a, b; Donoghue et al, 2005; Pääbo et al, 2004; Rault és Drancourt, 2008; Prüfer et al, 2010). A polimeráz láncreakciót PCRinhibítorok (huminsavak, fulvinsavak, tanninok, porfirin-termékek, fenolos vegyületek és I-es típusú kollagén) nehezítik, melyek a talajból és/vagy a biológiai anyag degradációjából származnak. A Maillard termék például nem inaktiválja a PCR-t, de képes gátolni azzal, hogy a cukorszármazékokat csapdába ejti, így megközelíthetetlenné válik a polimeráz enzim számára (Kemp et al, 2006). Ebből az következik, hogy az amplifikálása nehézkes. Archaikus minták esetében nagy a kontamináció veszélye, s így úgynevezett fals pozitív eredmények keletkezhetnek (Bouwann et al, 2012, Dabney et al, 2013 Campana et al, 2014; Müller et al, 2015). A környezeti hatások variációi (hőmérséklet, $\mathrm{pH}$, vízzel borítottság) a biomolekulák degradációját idézhetik elő (Pinhasi et al, 2015). A felsorolt jellemzők bármely aDNS-re igazak, a kezdeti, főként emlösönkön végzett aDNS kutatás után a patogének vizsgálatánál is igazolódtak (Donoghue et al, 2005). A bakteriális aDNS kimutatásával egyrészt megerösíthető pl. a csontokon specifikus nyomot hagyó gümőkóros megbetegedés diagnózisa, másrészt a nem tipikus, vagy nem egyértelmü morfológiát mutató esetekben az aDNS-eredmény segíthet igazolni a fertőzöttséget (Haas et al, 1999, 2000). Amint azt a korábbiakban ismertettük, az első, bakteriális fertőzésre irányuló aDNS kimutatást a kilencvenes éve elején Spigelman és Lemma $M$. tuberculosis-ra végezték el (Spigelman és Lemma, 1993). Idővel az is kiderült, hogy olykor a tbc baktérium DNS-e sokkal jobban megőrződött, mint a humán DNS, ami a kórokozó lipidgazdag sejtfalának, ill. a magas GC (guanin, citozin) arányának köszönhető (Zink et al, 2001, 2003; Donoghue et al, 2008). 


\subsection{Egységes kritériumrendszer a kontamináció elkerülésére - a hitelesség kritériumai}

A sok sikeres vizsgálat mellett számos problémás esettel is találkoztak az archeogenetika/paleomikrobiológia szakemberei. Esetenként az ősi mintákba DNSszennyeződés került, melyet a vizsgálatok aDNS-ként azonosítottak. Az ilyen fals eredmények tették szükségessé, hogy egységes kritériumrendszert alkalmazzanak az archeogenetikával foglalkozó kutatók. A vizsgálatok hitelessége szempontjából azt a célt tüzték ki, hogy minimalizálják a kontaminációt. Ennek megvalósítása a következőket betartva valósulhat meg§:

- a legoptimálisabb eset a kontamináció minimalizálására az lenne, ha már a feltárás során, a feltárást végző emberek is védőöltözetben lennének, így az adott régészeti korú csontanyag a feltárás során nem lenne kitéve a feltárást végző emberek exogén DNS-ének (Pääbo et al, 2004). (Ez a kritérium sajnos normál régészeti feltárás esetében sohasem valósulhat meg.);

- a legfontosabb kritérium, hogy egy fizikailag elkülönített, steril, ún. tisztaszobában történjenek a vizsgálatok, ezt nevezzük pre-PCR helyiségnek;

- nagy hangsúlyt kell fektetnünk arra, hogy egyéb, ill. exogén DNS jelenlétét kizárhassuk, ezért hipó és alkohol alkalmazásával DNS-mentessé tesszük a munkafelülelet, ill. a felszerelésünket, továbbá az eszközök autoklávozása és a munkatér 254 nm-en, UV-lámpával történő besugárzása alapvető;

- nélkülözhetetlen a maszk, kesztyü, köpeny, steril eszközök, speciális védőruha alkalmazása (Rafi et al, 1994; Salo et al, 1994; Donoghue et al, 1998; Zink et al, 2001, 2003; Drancourt et al, 2004; Pääbo et al, 2004; Kefi, 2011);

- nagyon fontos, hogy a pre-PCR helyiségben nagy koncentrációjú, recens DNS-t tartalmazó mintákat soha ne vizsgáljanak (Pääbo et al, 2004; Kefi, 2011);

§ Vizsgálataimat a felsorolt kritériumrendszerben dolgozó bolzanoi és budapesti laboratóriumokban végeztem el. 
- a csontok, amikor bekerülnek a pre-PCR helyiségbe, már átesnek egy hipóval történő tisztításon, ill. UV-sugárzáson. Ezt követően a csontokról a külső réteget eltávolítják, majd a porításuk egy zárt, perselyes csontmalomban történik (pl.: Retsch MM301 típusú malomban).

- a DNS extrakció, a mintavételi helytől elkülönített, de hasonlóan tiszta, DNSmentes, izoláló helyiségben történjen, ahol szürőrendszerek alkalmazásával csökkenthető a kontamináció (Rafi et al, 1994; Salo et al, 1994; Pääbo et al, 2004; Kefi, 2011);

- a vizsgálatok során minden reagens DNáz és RNáz mentesített, negatív kontrollok alkalmazása szükséges a mintákkal párhuzamosan, továbbá a keresztkontamináció elkerülése érdekében filterezett pipettahegyekkel folytatott munka szükséges (Donoghue et al, 1998; Zink et al, 2001, 2003; Pääbo et al, 2004; Kefi, 2011);

- a másik alapvető követelmény a hiteles aDNS vizsgálatok esetében a pre- és a poszt-PCR helyiségek teljes szeparálása (Zink et al, 2001, 2003; Pääbo et al, 2004; Kefi, 2011);

- a poszt-PCR helyiségekben a pozitív kontrollok használata humán minták esetében szükséges, míg paleomikrobiológiai vizsgálatoknál nem ajánlott (Zink et al, 2001). A kontamináció tovább csökkenthető molekulárisan specifikus targetek alkalmazásával (Drancourt et al, 2004; Keyser-Tacqui és Ludes, 2005);

- a kritériumokhoz az is hozzátartozik, hogy a laboratóriumban dolgozó személyzet genotipizálása megtörténjen (Pääbo et al, 2004; Kefi, 2011), mivel a vizsgálatok elvégzésére humán aDNA laboratóriumban került sor;

- mint minden más molekuláris biológiai vizsgálat esetén itt is igaz, hogy nagyon fontos a vizsgálatok ismételhetősége, ezért más laboratóriumokban a vizsgálati eredmények összehasonlítása hozzájárul az eredmények hitelességéhez (Zink et al, 2001).

Fontos azonban megjegyezni, hogy az új technológiák - mint a multiplex megközelítések, a qRT-PCR, az adapter-ligálás és a nagy áteresztőképességü DNS szekvenálás - nagymértékben javítják az endogén DNS kinyerésének arányát, továbbá 
csökkentik a kontamináció veszélyét és képesek lehetnek beazonosítani az emberi szennyeződést is (Krause et al, 2010; Haak et al, 2010; Deguilloux et al, 2011; Müller et al, 2015). 


\subsection{A mintavételi helyek - a mintavételek lokalizációja}

A paleomikrobiológiai kutatások kezdetén a kutatók úgy gondolták, hogy a betegségre utaló csonttani elváltozás helyéröl érdemes mintát venni a molekuláris vizsgálatokhoz, hiszen vélhetően innen könnyebb a kórokozó DNS-t kinyerni, mint a morfológiailag elváltozásmentes területekről (Salo et al, 1994). A 2000-es évektől egyre több publikáció jelent meg, ahol betegségre utaló csonttani elváltozást nem mutató régi maradványokból is képesek voltak kimutatni tbc-örökítőanyagot (Haas et al, 2000; Zink et al, 2001; Mays et al, 2002; Donoghue et al, 2005; Molnár et al, 2015). Mivel a tbc kórokozója a szervezetben vérárammal terjed, s jut el a szervezet szinte bármely pontjába, így a vérrel bővebben ellátott területekröl, pl. a csöves csontok velöüregi részéből érdemes mintát venni. A fogbélüreg szintén kiváló mintavételi hely lehet a mikrobiális DNS tekintetében (Zink et al, 2001; Donoghue, 2008; Dang La et al , 2008; Matheson et al, 2009; Nguyen-Hieu et al, 2011).

A humán paleopatológia számára nagyon fontosak az ismertetett molekuláris biológiai vizsgálatok, elsősorban azért, hogy a paleomikrobiológiai vizsgálatok számára releváns fertőző megbetegedés (pl. tbc, lepra) ténye azonosítható legyen nem tipikus csontelváltozások esetén is. A nem egyértelmű morfológia esetében a DNS szerepe döntő lehet a tényleges fertőzöttség bizonyításának tekintetében, valamint akkor is, amikor egyáltalán nincsenek látható nyomai a betegségnek a csontokon (Pósa et al, 2013).

$\mathrm{Az}$ archaikus patogénvizsgálatok mintavételeinek tekintetében a fogak és hosszúcsontok mellett a pars petrosa (sziklacsont) tünhet ideálisnak, jelenleg bizonyított, hogy utóbbi a humán endogén DNS vizsgálatok esetében a legjobb DNShozammal bír (Pinhasi et al, 2015). További kutatások szükségesek azonban annak tisztázására, hogy a pars petrosa MTB aDNS megtartása arányos-e az adott régió kiváló humán endogén aDNS megtartásával. 


\subsection{A fogak alkalmazása a paleomikrobiológiai vizsgálatok során}

Az első alkalom, amikor régi emberi fogakból mikrobiális aDNS-t mutattak ki, egy francia kutatócsoport hipotézisén alapult. Michel Drancourt és munkatársai feltételezték, hogy szeptikémiával járó kórfolyamat esetén a fogak alkalmasak lehetnek ezekre a vizsgálatokra. Egy, az 1720-22-es marseille-i pestisjárvány tömegsírjának vélelmezett lelőhelyről származó emberi maradványok esetében Olivier Dutour és munkatársai feltételezték a Yersinia pestis-sel történt fertőzést, de mivel a betegség a csontokon nem okoz semmilyen léziót, paleomikrobiológiai módszerre volt szükség a feltevés igazolására. Az 1990-es évek második felében elvégzett vizsgálatok kimutatták a fogakból a Yersinia pestis DNS-ét, első alkalommal igazolva, hogy a „fekete halál” évszázadokkal ezelőtti pusztítását a maival azonos kórokozó okozta. 2010-ben Haensch és munkacsoportja ezt a kutatási eredményt tovább pontosította (Drancourt et al, 1998; Haensch et al, 2010). A fogbél-üreg ideális jellege azzal függ össze, hogy a pulpa erőteljesen vaszkularizált szövet, mely mezenchimális eredetü. A dentin legbelső rétege a predentin, ez alatt húzódik az egy sejtsor vastagságú odontoblast, mely képzi a dentint. A következő réteg egy sejtszegény zóna, a legbelső rész pedig maga a pulpa, mely sejtes elemekben rendkívül gazdag. A fogak vaszkularizáltságuknak köszönhetően így az egyén halálának pillanatában nagy számban tartalmazhattak mikroorganizmusokat. A fogak tehát hasznosak lehetnek a hematogén úton terjedő, és különösen a szeptikémiát okozó mikróbák kimutatása esetén. Legfontosabb előnye a fogakkal történő vizsgálatoknak, hogy a külső környezettől védett, ami a talajból származó kontaminációval szemben limitálhatja a kockázatot. A fogak endogén DNS megtartása is kiváló (Zink et al, 2001; Gilbert et al, 2004, 2005; Drancourt et al, 2004, 2005, 2007; Dang La et al, 2008; Donoghue, 2008; Matheson et al, 2009; Nguyen-Hieu et al, 2011; Pinhasi et al, 2015). Az is bizonyítást nyert, hogy a fogak mikróba-DNS megőrzőképessége a tbc fertőzés esetén is számottevő lehet (Pósa et al, 2012a).

A paleomikrobiológiai vizsgálatok során, a fog mintavételi helyként való alkalmazásakor a következő protokoll betartása alapvető fontosságú: (1) a fognak intaktnak kell lennie, zárt apex-szel kell, hogy rendelkezzen, ami védi a külső környezeti kontaminációtól, (2) az egy gyökerü fogak ezeknél a vizsgálatoknál preferáltabbak, (3) több mint egy fog alkalmazása szükséges egyénenként. 
Az elemzést megelőzően a fogak kezelése szükséges, a külső felszínt hipózzuk, majd UV kezelésnek vetjük alá, ezt követően megtörténhet a fogak fizikai roncsolása, azaz finom porrá őrüljük, ezzel előkészítve a DNS-kinyerésre. Egy másik eljárás során, egy résen keresztül kaparásos módszerrel juthatunk a pulpa-maradványokhoz.

A különböző kontrollok alkalmazására itt is komoly hangsúlyt kell fektetni. A pozitív kontrollok alkalmazását mellőzzük, ahol ősi mintákkal dolgozunk (Zink et al, 2001; Dang La et al, 2008; Nguyen-Hien et al, 2011). A negatív kontrollok esetében is számos kritérium betartása szükséges az elfogadható eredmények érdekében: (1) több negatív kontrollt kell elemezni párhuzamosan a mintákkal, (2) a negatív kontrollok a lehető legjobban hasonlítsanak az ösi mintákhoz, (3) amplikonmentesnek kell lenniük. A modern baktérium okozta kontamináció abban az esetben kizárható, ha a kinyert mikrobiális aDNS szekvencia a kórokozó ősi mivoltára utaló deléciót vagy más mutációt jelez.

\subsection{Amplifikációmentes vizsgálati módszerek - lipid biomarkerek}

Minden Mycobacterium tartalmaz hosszúláncú, 60-90 szénatom számú zsírsavláncokat, mycolsavakat és egyéb más sejtfalkomponenseket. Ezek közül elsőként a mycolsavakat ismerte fel a paleomikrobiológia tudománya, hogy a korabeli MTBfertőzöttség kimutatásánál biomarkerként használhatók (Minnikin et al, 2002). 


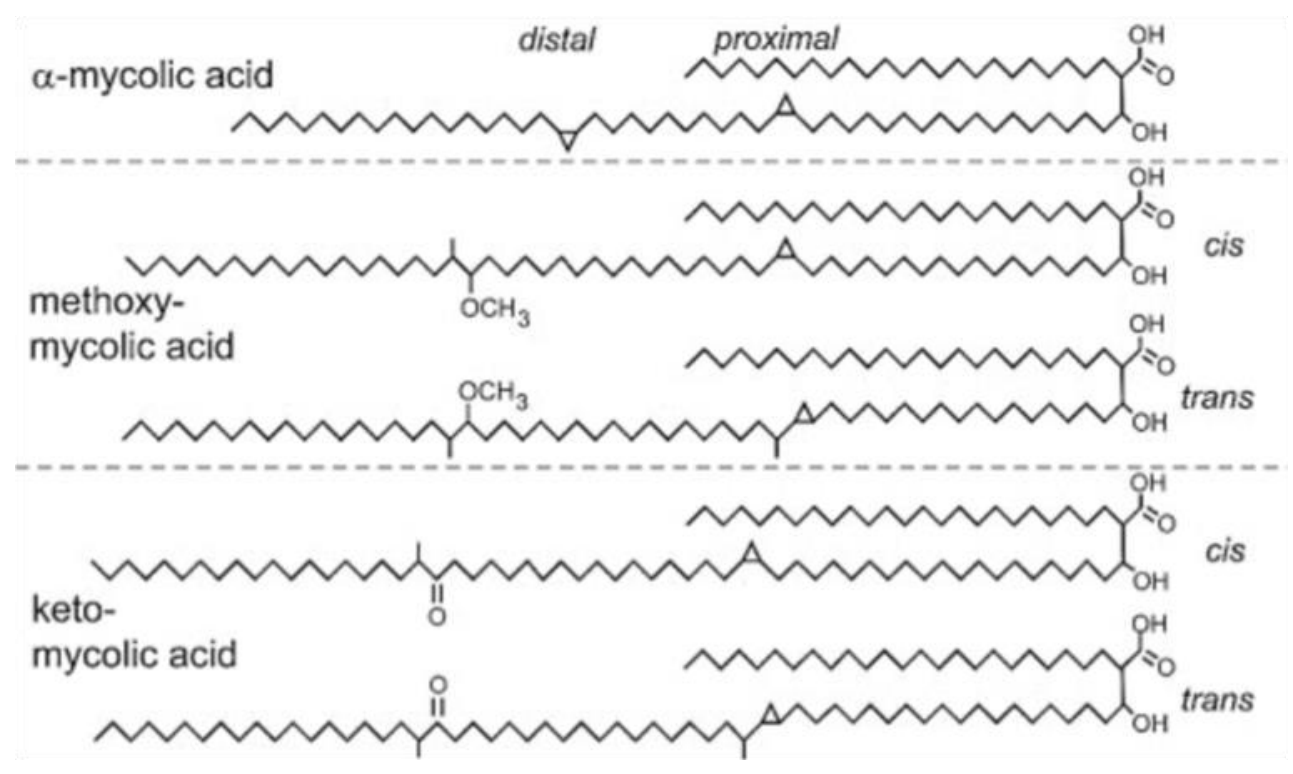

8. ábra: Mycolsavak szerkezeti képlete.

A Mycobacterium sejtfal, ahogyan arról már a disszertációm korábbi fejezetében írtam, hidrofób, nem permeábilis $\mathrm{s}$ rendkívül ellenálló a károsodásoknak és degradációnak (pl. savaknak és alkoholoknak is ellenáll) - a baktérium ennek köszönhetően képes túlélni a gazdaszervezetben (Ryan és Ray, 2004). A mycobacteriumok sejtfalának gyakorta magas lipidtartalmáért egy lipid-poliszacharid, a LAM (lipoarabinomannan) felelős, mely jellemző a Gram-negatív baktériumoknál is; egy olyan réteg, ami a teljes sejtfal vastagságának jelentős részét teszi ki. Sok elágazó láncú poliszacharid és kapcsolt lipidek, porinok és más fehérjék találhatók a sejtfalon (Ryan és Ray, 2004) (8. ábra).

A mycolsavak független azonosítást tesznek lehetővé, a metodika HPLC (magas teljesítményü folyadék kromatográfia) alapú, mely magas specifitású a tuberkulózis és a lepra kutatásában. Ebben az esetben nincs szükség a célmolekula amplifikálására (Donoghue, 2008; Rault és Drancourt, 2008, 2011; Minnikin et al, 2011). Abban az esetben, ha nagyon töredékes a DNS, elvégezhető a mycolsavakkal történő molekuláris vizsgálat, s így igazolhatja a bakteriális fertőzés tényét, vagy DNS vizsgálatokkal kombinálva megerősítő analízisként is szolgálhat (Minnikin et al, 2011). A vizsgálati módszer igen költséges, ill. a berendezés és a szükséges szakértelem kevéssé elterjedt, így általában kiegészítő vizsgálatként alkalmazzák a bakteriális aDNS vizsgálatok mellett (Donoghue, 2008).. 


\subsection{1 Újabb irányvonalak az archaikus tbc kutatásban - NGS}

A 2000-es évek közepétől datálható, napjainkra egyre szélesebb körben elterjedő ún. újgenerációs szekvenálási (Next-Generation Sequencing - NGS) technikák nem hagyták érintetlenül a patogénkutatást sem. A módszer technológiai előnyei elsősorban lényegesen nagyobb-mélyebb felbontási képesség és az ebből következő, az első generációs szekvenálási módszer adatkihozatalát exponenciális módon meghaladó adatkinyerés - lehetővé tették jelentősen hosszabb DNS-szakaszokra szekvenálását (Chan, 2009, Knapp és Hofreiter, 2010; Rizzi et al, 2012). Az ún. WGS-alapú (Whole Genome Sequencing) megközelítés rutinszerüvé válása figyelhető meg a humán mitokondriális örökítőanyag kutatásában. Az NGS-technológia előnyei több ok rendkívüli forrásigény, a kapott adatok kiértékelésének biostatisztikai nehézségei, a bioinformatikai interpretáció problematikussága - miatt még nem tudtak jelentőségüknek megfelelő módon megmutatkozni az archaikus kórokozók molekuláris genetikai kutatásában. Néhány jelentősebb laboratórium és nemzetközi kutatócsoport közölt már NGS-technológián alapuló jelentős eredményeket, nagyrészt a mitokondriális DNS analízisével, ezek elsősorban archaikus humán mintákon, illetve recens adatokból készített adatbázisokon alapultak (Mathieson et al, 2015).

A patogének tekintetében eddig elsősorban screen-jellegü, multiplex vizsgálatokat végeztek, ezek azonban szinte kizárólag a kutatott patogéncsoportok elsődleges kimutatására irányultak, az egyes típusok egyedi meghatározására/elkülönítésére nem (Schuenemann et al, 2013). Az NGS technológia alkalmazása utóbbi években a tbc paleomikrobiológia kutatásában is megjelent (Chan et al, 2013; Bos et al, 2014; 2015 Kay et al, 2015). Egyelöre azonban nagyon kevés az archaikus tbc-vel összefüggő, jól intrepretálható metagenomikai eredmény, elsősorban az NGS-vizsgálatok rendkívül költségigényes mivolta miatt. Az eddigi első eredmények múmiákból származnak, a régi humán csontanyagok NGS tesztelése néhány külföldi laboratóriumban megkezdődött, de technológiai nehézségek miatt egyelőre még nincsenek publikált eredmények.

Ezek az egyre pontosabb detektálási módszerek a Mycobacterium tuberculosis esetében kulcsfontosságú eljárások, hiszen a talajban is előforduló nem tuberkuloid 
Mycobacterium törzsek jelenléte nehézséget okoz a tbc detektálásában, reményeink szerint ezekkel az új szekvenálási eljárásokkal pontosan azonosíthatóvá válik az ősi mycobacteriumok DNS szekvenciasorrendje is. 


\section{Célkitüzések}

Az archeogenetikai kutatások Magyarországon jelentős múlttal rendelkeznek, elsőként Szegeden Raskó István és munkacsoportja (Magyar Tudományos Akadémia Szegedi Biológiai Kutatóközpont, Genetikai Intézet) kezdett el humán DNS kimutatással foglalkozni történeti korú csontmaradványokból, majd 2003-tól Budapesten a Magyar Tudományos Akadémia, Régészeti Intézet, Archeogenetikai Laboratóriuma. A bakteriális DNS detektálása humán csontmaradványokból azonban eddig még nem volt jelen a magyarországi vizsgálatok palettáján, a disszertációmban bemutatott kutatásokkal kívánom bemutatni azokat a folyamatokat, melyek ahhoz szükségesek, hogy a jövőben meghonosítható legyen Magyarországon is a tbc paleomikrobiológiai kutatása.

A bolzanoi EURAC Institute For Mummies And The Iceman, amint az intézet neve is jelzi, az 5300 éves jégbefagyott ,jégember”, Ötzi múmiájának komplex vizsgálatát tüzte ki többek között célul. Bejáratott módszerekkel vizsgálnak különböző bakteriális fertőzéseket is régészeti korú emberi maradványokon, így, többek között a Mycobacterium tuberculosis komplex aDNS-maradványokat is kutatják.

Mivel Magyarországon a morfológiailag gümőkórként leírt régi esetek száma jelentősnek mondható (pl.: Pálfi et al, 1999; Pálfi és Marcsik, 1999; Pálfi, 2002; Pálfi és Ardagna, 2002; Maczel, 2003; Marcsik et al, 2009; Lovász, 2015), ezért aktuálissá vált, hogy a technológiai fejlődésnek megfelelően, molekuláris vizsgálatokkal is alátámasszuk ezen adatokat. A mai vizsgálati módszereket nézve, mycobacteriális fertőzések (tbc, lepra) esetén megkerülhetetlen fontosságú a paleopatológiai vizsgálati eredmények molekuláris adatokkal történő megerősítése. A tuberkulózis kutatásában Magyarországon is nélkülözhetetlen a mycobacteriumok archeogenetikai/

\footnotetext{
*Doktori munkám során összesen hat alkalommal folytathattam kutatásokat a tbc-paleomikrobiológia nemzetközi szinten is elismert laboratóriumában, a EURAC Research, Institute for Mummies and the Iceman (dir: Prof. Albert Zink) aDNS laboratóriumában (Bolzano, Észak-Olaszország) található. Kutatásaim első felében valamennyi vizsgálati fázisra az olaszországi tanulmányutak keretében, és a bolzanoi laboratóriumban került sor, míg tanulmányaim második felében, a paleomikrobiológiai kutatások hazai meghonosítása érdekében, már bizonyos részfeladatokat magyarországi laboratóriumban, az MTA BTK, Régészeti Intézet Archeogenetikai Laboratóriumában végeztem el.
} 
paleomikrobiológiai vizsgálatával is foglalkozni, és szükséges hazánkban is meghonosítani ezeket a vizsgálatokat, hogy képesek legyünk versenyképes kutatásokkal hozzájárulni a nemzetközi eredményekhez.

Doktori kutatásaimban célul tüztem ki:

- a Mycobacterium tuberculosis komplex aDNS kinyerési és elemzési technikák elsajátítását külföldi partnerlaboratóriumban, és azok gyakorlati alkalmazását hazai embertani maradványok esetében;

- a baktérium aDNS kinyerése szempontjából optimális anatómiai lokalizációk meghatározását az archaikus csontmaradványokban, elsősorban hosszúcsontok és fogak alkalmazásával (a korábban alkalmazott csigolyák és bordák helyett, illetve szükség esetén azokkal együttesen);

- a Kárpát-medence több történeti-régészeti korszakában - különösen a tbc paleoepidemiológiája és demográfiai hatása szempontjából kiemelt korszakok esetén igazolni kívántam a mycobacteriális fertőzések jelenlétét molekuláris biológiai eredményekkel, hogy komplementer vizsgálatként alátámasszam a korábbi morfológiai vizsgálatok eredményeit, és segítsem a régi népességeink komplex biológiai-történelmi rekonstrukcióját. Ahhoz, hogy történeti távlatokban, térben és időben megfigyelhessük a tuberkulózis terjedését, szükséges különböző korszakokban nyomon követni a fertőzések jelenlétét. Megfelelően kiválasztott, konkrét időintervallumokat kijelölve jó rálátást kaphatunk a paleoepidemiológiai adatokról - doktori kutatásaim során ezeket a szempontokat is figyelembe véve a neolitikumtól az újkorig, a Kárpát-medence történeti időszakában vizsgáltam a Mycobacterium molekuláris jelenlétét;

- az archaikus mycobacteriális fertőzések molekuláris hátterű azonosításának elökészítését Magyarországon, annak érdekében, hogy a későbbiekben hazai körülmények között is validálni lehessen a külföldön elsajátított korszerü vizsgálati módszereket, és hogy később azokat rutinszerüen alkalmazni lehessen magyarországi minták esetében. 


\section{Anyagok és módszerek}

\subsection{A neolitikum}

\subsubsection{A neolitikum - az újkőkori forradalom}

$\mathrm{Az}$ újkőkori forradalom elnevezés méltán jelzi azoknak a nagy horderejü változásoknak a jelentőségét, melyek az addigi világ radikális átalakulását eredményezték. A növénytermesztés megjelenése, az állatok háziasítása, a kerámiamüvesség kialakulása, az eszköz- és szerszámkészítés új technikáinak kifejlődése olyan láncreakciót indított el, melynek hatása napjainkig érezhető. A korábbi vándorló, halászó-vadászó, gyüjtögető életmódról a letelepedett, földművelöállattenyésztő életmódra, azaz a mezőgazdasági termelésre való fokozatos áttérés teremthette meg mai világunk gazdasági és társadalmi alapjait.

Ennek a folyamatnak az időbeli és térbeli kialakulását a kutatás az ún. Termékeny félholdnak nevezett térséghez köti (Délkelet-Anatólia, Irak, Irán, Szíria és Egyiptom Nílus menti területe), ahol kb. 12.000 évvel ezelött több helyen voltak adottak olyan kedvező feltételek (mint pl.: egyes gabonanövények és tenyésztett állatok vad formái), melyek lehetővé tették a korábbi életmód gyökeres átalakulását (Özdoğan, 2008; Robson, 2010; Holl, 2015). Az újkökori innovációk, köztük a legfontosabbak, a növénytermesztés és az állattenyésztés ismerete kb. 4000 évvel később érhette el Délkelet-Európa területét, majd később Európa többi részét is, ahol a termesztett növény- és háziasított állatfajok, fôként a gabonafélék és a kis kérödzők (juh/kecske) vad ösei korábban nem éltek (Perlès, 2005).

Arra vonatkozóan, hogy ezek az új ismeretek hogyan, milyen ütemben, valamint, hogy mikor terjedtek el Európa egyes részein, az őskor kutatása számtalan elméletet dolgozott ki, melyek V. Gordon Childe első elméleti megfogalmazása óta nagy utat jártak be (Childe, 1959). Az ezzel foglalkozó kutatások különböző forrásanyagokra támaszkodva - mint pl.: az archaeozoológia, az archaeobotanika, a radiocarbon keltezés vagy éppen a genetika -, alkották meg a neolitizációval kapcsolatos elképzeléseiket. A fö kérdése azonban ezeknek az irányzatoknak ugyanaz volt, azaz, hogy vajon bevándorló népcsoportok hozták-e magukkal az új ismereteket, vagy pedig a tudást, az új ismeretanyagot emberek vagy népcsoportok egymás között adták tovább, és így 
terjedhetett el fokról fokra, lépésről lépésre. A modellek szintjéig kidolgozott elméletek széles spektrumon mozognak. Voltak, akik az innovációk hullámokban való terjedését modellezték, mely a földművelés gyors terjedésével és a földművelők egyértelmű dominanciájával számolt (Ammerman és Cavalli-Sforza 1973; 1984). A migráció elsődlegességét, azaz a népcsoportok bevándorlását ugyanakkor több kutató is hangoztatta, mely a népcsoportok genetikai keveredéssel is együtt kellett járjon (Renfrew 1987; Bogucki és Grygiel 1993; Lalueza-Fox, 1996; Richards et al., 1997; Zvelebil, 1998; 2001; Pinhasi és von Cramon-Taubadel, 2009). Más elméletek azonban ún. érintkezési zónákban, a földművelők és a gyüjtögetők közötti cserekapcsolatokkal magyarázták az újkőkori vívmányok terjedését, mely feltételezi, hogy, ha volt is genetikai keveredés, annak jelentősége korlátozott és lokális lehetett (Zvelebil, 2000; Barker, 1985; Dennel, 1992). Ezekhez az elméletekhez az utóbbi években nagymértékben hozzájárultak az archaeogenetikai vizsgálatok és azok eredményei.

Az Európa kontinentális részein megjelenő első települések általában nagyobb folyóvölgyek mentén, kiterjedt löszhátságokon alakultak ki, vagy pedig a tengerparti vidékeken, mint amilyen a Mediterráneum térsége. Mivel Európa jelentős részének földrajzi jellemzői, éghajlati adottságai meglehetősen eltértek a Termékeny félhold vidékének természetföldrajzi viszonyaitól, az innovációk átvételét az itteni körülményekhez kellett igazítani. Ezt jelzi például a kecske és juh háziasításával kapcsolatos probléma, hiszen az eltérő klíma miatt a Kárpát-medencében a domesztikáció során sokkal nagyobb szerep jutott a háziasított szarvasmarhának, és ősének, az őstuloknak.

A nagy anatóliai-balkáni korai neolitikus komplexum legészakabbi elterjedési határa épp a Kárpát-medencében húzódott, ahol a legkorábbi földművelők tárgyi emlékanyagát a Körös-, Criş és Starčevo-kultúráknak elnevezett régészeti egységekben azonosíthatjuk. Első településeik időbeli megjelenése ma már abszolút kronológiai dátumokban is jól kifejezhető, mely szerint nagyjából a Kr.e. 6. évezred legelején jelentek meg e népcsoportok hazánk területén (Oross és Siklósi, 2012; Oross et al, 2016). Az Alföldön megtelepedett Körös-kultúra kutatása régebbi múltra tekint vissza és jóval több lelőhelye ismert (Anders és Siklósi, 2012), mint a Balatontól délre lévő területeken megtelepedett Starčevo-kultúráé, melynek kutatása csak a 70-es években 
indult meg (Kalicz, 2011, Bánffy et al, 2010, Oross et al, 2016). Az azóta eltelt időben már nagykiterjedésü településük is ismertté vált Alsónyék-Bátaszéken, ahol nagy mennyiségü és gazdagon díszített kerámiaanyag, számtalan kemence, és kb. 30 csontvázas temetkezés került elő (Bánffy et al, 2010; Köhler, 2015; Oross et al, 2016). Mivel ezek a népcsoportok a korai neolitikus civilizációk legészakabbi elterjedési határát jelentették, így döntő szerepük volt abban, hogy a neolitikus vívmányok csaknem Európa egész területén elterjedhettek. Ennek a hosszú folyamatnak az eredményeként jött létre a különböző vonaldíszes kerámiákkal fémjelzett időszak, melynek nagykiterjedésű települései a Párizsi-medencétől egészen Ukrajnáig megtalálhatók. Jellegzetes, vonaldíszekkel karcolt kerámiáik, földfelszínre épített oszlopszerkezetes, masszív lakóépületeik nyomai nagyfelületű feltárások nyomán láttak napvilágot. E látszólagos homogenitás mögött azonban megannyi sokféleség bújt meg, több regionális csoportot és változatot eredményezve. Újabban a Dél-Dunántúl területén sikerült kimutatni, főként az elökerült kerámiaanyag alapján, egy erőteljes balkáni hatásokat mutató csoportot (Marton és Oross, 2012; Jakucs és Voicsek, 2015).

Részint a vonaldíszes kultúrák hagyományain kialakulva jelentek meg a már késő újkőkorhoz sorolt, és egyben az újkőkori fejlődés csúcsát reprezentáló régészeti egységek. Ez az Alföldön a virágzó tell-kultúrák időszaka, a Tisza-Herpály-Csőszhalom komplexummal, ill. a disszertációmban tárgyalt Vésztő Mágori-domb lelőhellyel, mely időben nagyjából egybeesik a Dunántúlon kialakuló ún. Lengyel-kultúra megjelenésével, mely területünkön kb. a Kr.e. 4900-4300 közötti időszakot öleli fel. E nagy kiterjedésü kör sajátos, vörössel, sárgával, fehérrel és gazdag geometrikus mintakinccsel festett kerámiaanyaga számtalan lelőhelyen került elő a szomszédos országok területén is, így Szlovákiában, Ausztriában, Csehországban, és kissé módosult formában Lengyelország területén, valamint a Dráván túli vidékeken is (Horváthné Simon, 2003; Takácsné Biró, 2003) ** A kutatás a Lengyel-kultúra két nagy térbeli egységét különbözteti meg, egy keleti és egy nyugati tömböt, melyek számos ponton mutatnak lényeges eltéréseket is. A nyugati elterjedési területről főként településeket, és emblematikus körárkos lelöhelyeket ismerünk, melyek nagyban meghatározták a

** Az irodalomjegyzékben ld. H. Simon K. és T. Biró K. 
kutatás irányait is. Itt említhetjük például, hogy Ausztriában a körárkos lelöhelyek kutatására részletes módszertant dolgoztak ki a légifotózás és magnetométeres felmérések segítségével. Egyelőre még magyarázatra vár az a jelenség, miszerint a nyugati elterjedési területről hiányoznak azok a nagyméretü temetkezési helyek, melyek azonban a keleti elterjedési területen megvannak (pl.: Svodín, Aszód, DélkeletDunántúl). Ezek a leletanyagok a sírokban talált tárgyak klasszifikációs rendszereinek kidolgozását, valamint a társadalomrégészeti szempontú vizsgálatokat ösztönözték inkább (pl.: Zalai-Gaál, 2001). Magyarország területéröl jelenleg a Lengyel-kultúra több mint 300 lelöhelyét ismerjük, ezen belül is a Délkelet-Dunántúlon, Baranya és Tolna megyék területén különös településkoncentrációval számolhatunk. Ennek okai többek között a Mecsek hegység rendkívül gazdag kőnyersanyag lelőhelyeiben keresendők. A régebbről ismert és újonnan előkerült körárkos lelöhelyeken kívül (Bertók-Gáti, 2014), nagy sírszámú temetőket ismerünk innen, mint amilyen Lengyel, Mórágy vagy Zengővárkony (Zalai-Gaál, 2001), illetve a legutóbb Alsónyék-Bátaszéken feltárt nagy kiterjedésü lelöhely közel 2300 temetkezésével és 122 oszlopszerkezetes épület nyomával (Osztás et al, 2012).

\subsubsection{A földmüvelés, növénytermesztés és a domesztikáció megjelenése a neolitikumban}

Az újkőkor kezdetén elinduló változások természetszerüleg a mindennapi élet egész területét áthatották. A művelés alá vont földek mennyisége fokozatosan nőtt, és ezeknek az élelemforrásoknak az egyre intenzívebb kihasználása egyfelől demográfiai növekedést vont maga után, másfelöl pedig a közösségek számára addig elérhető közelségben lévő források kiapadását is okozta. Ezért kellett újabb és újabb területeket müvelés alá vonni, mely sok esetben idézte elő egyes népcsoportok addigi lakóhelyükről történő elvándorlását is. Az élelemtermeléssel és a letelepedett életmóddal együtt járó magasabb létbiztonság nagy létszámú embercsoportok együttélését tette lehetővé, mely idővel állandó falvak megjelenését is eredményezte, ahol adott esetben nagyszámú ember élt együtt.

Az élelemtermelésre való áttéréssel különböző betegségek megjelenésével is számolhatunk, melyek detektálását az újkőkor előtti időszakokhoz képest a lelőhelyek 
megszaporodása, és az ezekről előkerült nagyszámú embertani anyag tette lehetővé. A betegségek vizsgálata az egykor élt emberek csontvázain részint a fizikai antropológia eszközeivel, másrészt fejlettebb eljárások bevonásával kutathatók.

A csontléziók azt sugalják, hogy az emberi szervezet adaptálódott a földmüveléshez, ami pedig annak a következménye, hogy az új életfeltételeknek köszönhetően növekedett a fertőző betegségek aránya. Ismert példa, ha növekedés során az egyén szervezetét stressz éri az élelemmegvonás következtében a fogakon és a csontokon „,vonalkázottság” figyelhető meg (Robson, 2010). A neolit népesség táplálkozásában és életvitelében drasztikus változás állt be, ez drámai hatással volt a neolit emberekre. A vadászó-gyüjtögető emberek kisebb csoportokban éltek együtt, így a szociális élet is szűkebb keretek között mozgott, a fertőző betegségek kialakulására és terjedésére is kevesebb lehetőség adódott. Az állatok közelsége is a fertőző betegségek megjelenését erősítette, a ház körül élő, egyes esetekben a házon belül tartott állatoknak köszönhetően a zoonózis mindennapossá vált. A vizek az emberek által termelt hulladékok miatt parazitákkal fertőződhettek, így az állatok és emberek szervezetébe szabadon bejuthattak különböző fertőző ágensek (Latham, 2013). A fentiek alapján a tuberkulózis terjedésére, gyakoribbá válására is kedvező feltételek alakulhattak ki a neolitizációval.

\subsubsection{Alsónyék - Kanizsa-dülő lelöhely 13-as sírcsoportja - Lengyel kultúra}

Alsónyék-Bátaszék lelőhely a Dél-Dunántúlon, a Duna közelében helyezkedik el. A prehisztorikus település és temető feltárására 2006 és 2009 közötti időszakban került sor. Összesen 2359, késő neolit-kora rézkori Lengyel kultúrából (Kr.e. 5. évezred első fele) származó sírhelyet tártak fel (Köhler et al, 2012; Köhler et al, 2013; Zalai-Gaál et al, 2008). Mai ismereteink szerint ez az egyik legrégebbi és legnagyobb feltárt neolitkori település Közép-Európában. Az Alsónyék-Bátaszék lelöhelykomplexum (9. ábra) része az az Alsónyék-Kanizsa dűlő (vagy 010/B), ahol a feltárt 862 sír egyikéből került elő az első tbc-gyanús paleopatológiai eset (Zalai-Gaál et al, 2009). Jelentősége ebben áll, hiszen populáció szinten nagymértékű feldúsulás figyelhető meg, majd hirtelen kollapszus, ahol figyelembe kell vennük a tuberkulózis-fertőzöttségre utaló 
elváltozást. A sírok kisebb-nagyobb csoportokba rendezettek, ezért kronológiai és/vagy családi temetkezés feltételezhető. A sírokban a holttestek zsugorított temetkezésnek megfelelően a jobb oldalukra fektetve helyezkedtek el, ami szokványosnak mondható ebben az időszakban.

A 13. sírcsoporthoz tartozó csontvázak morfológiai vizsgálata során Köhler és munkatársai feljegyeztek egy igen látványos, krónikus Pott-gibbus-t mutató esetet (4027-es sírszám) (ld. később, 13. ábra) (Köhler et al, 2012). Ez a 4027-es sírszámú csontvázmaradvány a krónikus spondylitis tuberculosa egyértelmü, teljesen tipikus formáját mutatja, minden szempontból megfelel a tuberkulózis makromorfológiaipaleopatológiai diagnosztikus követelményeinek (pl.: Pálfi et al, 1999; Ortner, 2003). A molekuláris vizsgálatokba 38 egyén csontvázát vontuk be a szóban forgó sírcsoportból közöttük a fentebb említett elöre haladott Pott-gibbus-os esetet is (Pósa et al, 2015b, 2016a). Az SZTE TTIK Embertani Tanszékén végzett előzetes morfológiai vizsgálatunk alkalmával a csontvázakon egyaránt tanulmányoztuk a tipikus és korai/atípusos tbc-tüneteket. A széria jó megtartási állapota, a fontos régészeti időszak és a tbc különböző morfológiai tüneteinek felismerése együttesen arra ösztönöztek bennünket, hogy minden egyénre kiterjedő, tbc-re fókuszáló archaikus DNS vizsgálatokat végezzünk az Alsónyék-Kanizsa dülő teljes 13-as sírcsoportja esetében. 


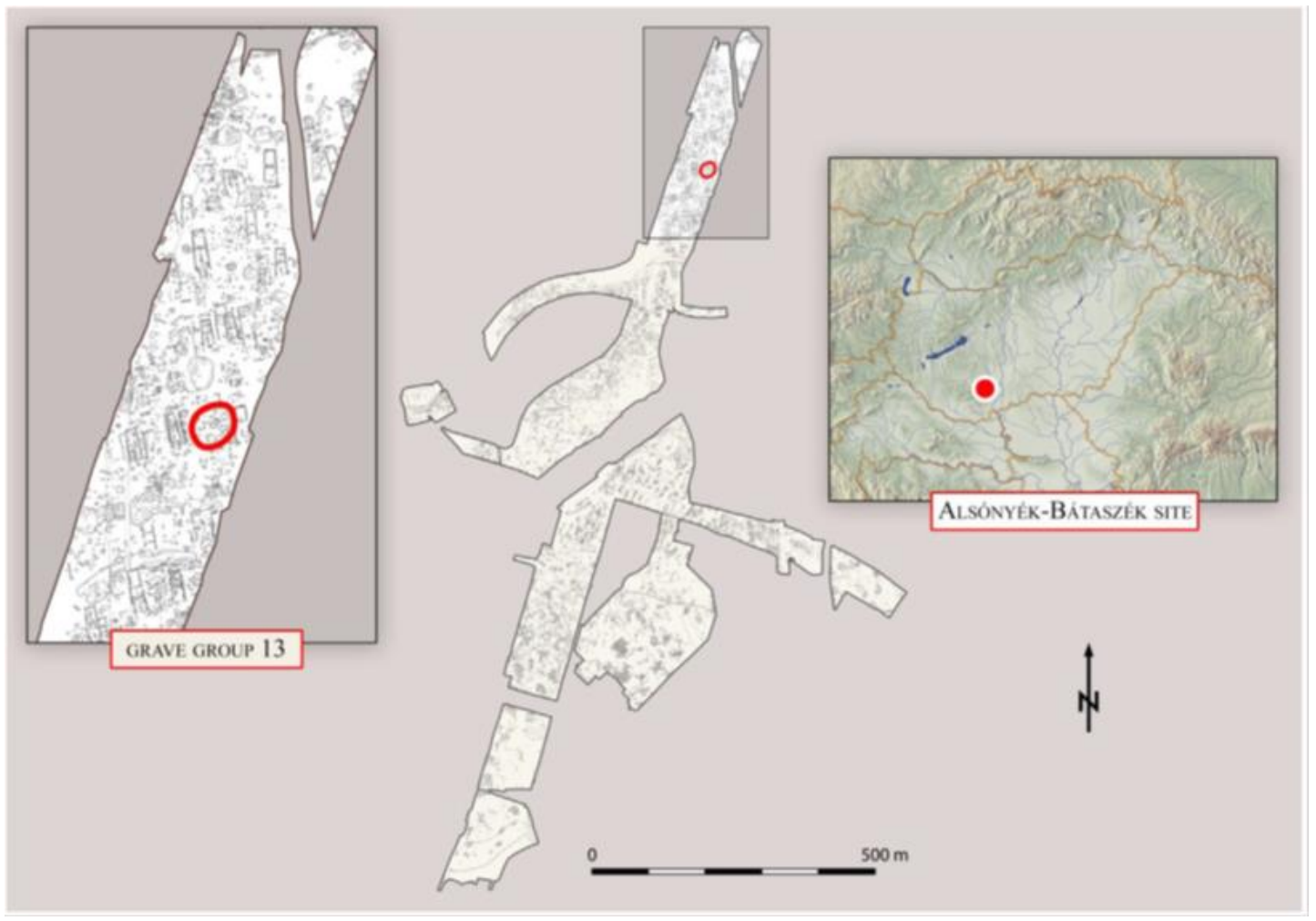

9. ábra: Áttekintő térkép az Alsónyék-Bátaszék neolit lelőhelykomplexumról. A 13-as sírcsoport piros körrel jelölve (Pósa et al, 2015b).

A paleomikrobiológiai kutatásokkal párhuzamosan régészeti vizsgálatok zajlottak, a radiokarbon, szénizotóp $14\left({ }^{14} \mathrm{C}\right)$ adatok szolgáltatnak információt a temető koráról. A vizsgálatokba elsőként fogakat vontunk be a csonttani anyagból, mivel korábbi vizsgálatok alapján alkalmas mintavételi helynek bizonyult (Nguyen-Hieu et al, 2011, Pósa et al, 2012a). A fogak mellett egy hosszúcsont mintát is vettünk a kontroll vizsgálatok érdekében, arra az esetre, ha a fog negatív mintát szolgáltat. A mintavétel a budapesti Archeogenetikai Laboratórium mintavételi helyiségében történt, erre a lépésre azért volt szükség, hogy megakadályozzuk a minták kontaminálódását továbbá a vizsgálatok előkészítése is itt zajlott. A paleomikrobiológiai vizsgálatokra a EURAC Institute for Mummies and the Iceman bolzanoi kutatólaboratóriumában került sor.

\subsubsection{Vésztő Mágori-domb lelőhely neolit temetője - Tiszai kultúra}

Vésztő a Dél-Alföldön, Békés megye északi részén, a Holt-Sebes-Körös bal partján található. A 150-153 méter hosszú, 100 méter széles és 7-8 méter magas tell 
rétegei különböző korok leleteit tartalmazzák, megtalálhatók itt a neolit elejétől a bronzkor végéig számos kultúra emlékei - Körös Kultúra, Alföldi Vonaldíszes Kerámia (Makkay, 2004).

Az első ásatásokra 1972-1976 között került sor Hegedüs Katalin vezetésével, ekkor összesen 44 sírt tártak fel, melyek a neolitikumból és a rézkorból származtak - a neolit sírok száma 27. A Tiszai kultúrából származó sírok esetében a fa koporsós temetkezés nyomai lelhetők fel. A sírokra a zsugorított temetkezés jellemzö, a férfiakat, föként a jobb, míg a nőket a bal oldalukra fektették, azonban akad néhány kivétel (férfiak bal oldali fektetése: 7, 13-14, 16, 36, 39, 42. sírok esetében, ill. a nők jobb oldali fektetése: 1. sír esetében). Edény mellékletet csak a 1. és a 31. sírban találtak a régészek. A halotti rítusra jellemző, hogy okkerrögöt helyeztek az elhunyt tenyerébe (Makkay, 2004).

Az ásatások második fázisa 1986-ban Makkay János és Juhász Irén vezetésével zajlott le, ahol további hat sírt tártak fel - három rézkori és három neolit sír került elő.

Az antropológiai vizsgálatok során 31 egyén maradványait fedezték fel, ahol két meghatározhatatlan nemü felnőttet, kilenc gyermeket, négy felnőtt nőt, 14 felnőtt férfit jegyeztek fel, három egyén esetében nem volt antropológiai vizsgálat - ebből kettő felnőtt és egy gyermek (kettős temetkezés egy sír esetében) (Spekker et al, 2012). Érdekes megfigyelés, hogy a csecsemőkorúak teljes mértékben hiányoztak a feltárt sírokból.

A radiokarbon kormeghatározás adatai alapján Kr. e. 4900-4500-ból származnak a maradványok (Siklósi Zsuzsanna doktori disszertáció, 2010).

Molekuláris vizsgálataimba öt egyén csontvázát vontuk be, amelyek esetében négy egyénnél a paleopatológiai vizsgálatok során felmerült az esetleges tuberkulózisfertőzés. 


\subsection{A bronzkor}

Tápé-Széntéglaégető lelőhely késő bronzkori temetőjéből, az innen előkerült emberi maradványok Kr. e. 14-13. századból származnak. A régészeti feltárásokat Trogmayer Ottó vezette 1960-1966 között, amelynek során 686 sírra tártak fel. Az antropológiai vizsgálatok eredményeit 1971-ben Farkas L. Gyula és Lipták Pál közölték, közlésük alapján 389 zsugorított helyzetben eltemetett, 36 urnasíros, 49 nyújtott helyzetü temetkezést, ill. 212 bolygatott sírt írtak le. Az embertani vizsgálatokba a csontok rossz megtartási állapota miatt összesen csak 579 sírt vontak be.A vizsgált egyének esetében a demográfiai megoszlása a következő volt: 186 férfi, 159 nő, 162 gyermek és 72 meghatározhatatlan nemü egyént (Farkas és Lipták, 1971).

A paleopatológiai vizsgálatok hét egyén esetében igazoltak tbc-vel összefüggésbe hozató atípusos tüneteket (Spekker Olga PhD kutatás, SZTE Embertani Tanszék). 


\subsection{Az avar kor}

Az avarok nem tekinthetőek egységes népcsoportnak tárgyi-szellemi müveltségük és származásuk tekintetében, azonban mégis egységesnek tekintjük a 6. század és 9. század közötti régészeti kultúrát a Kárpát-medencében. Az avarokat 18. században Joseph de Guignes azonosította a kínai forrásokból ismert belső-ázsiai zsuanzsuanokkal. A későbbiekben Czeglédy Károly Theophilaktos pszeudo-avar történetében varchonita néven leírt avarokat heftalita (fehér hun), tehát közép-ázsiai eredetünek határozta meg. Bóna István 1971 és 1980 között a két történeti elméletet egyesítve kidolgozta az avarok kettős eredetének régészeti érveken alapuló hipotézisét, miszerint az avarok Közép- és Belső-Ázsiából származó népcsoportok egybeolvadásával jöttek létre (Pohl, 2002). A keletről érkező avarság Kelet-Európában bolgár-török (kutrigur és utigur) elemekkel, majd a Kárpát-medencében jelentős számú germán (gepida és langobard) és romanizált népességgel bővült, de számolnunk kell szláv nyelvű lakosság jelenlétével is a területen (Vida, 2009).

A Szeged-Kiskundorozsma Kettőshatár I. lelőhely feltárását az M5-ös autópálya nyomvonala mentén 2004-ben, Mészáros Patrícia, Paluch Tibor és Szalontai Csaba régészek végezték. A sírok rendkívül sürün helyezkedtek el, a 7-9. századból származó temetőt egy korábbi 4-5. századból származó sírokra temették rá, ill. modernkori bolygatás is megfigyelhető, de a csontvázak esetében általánosságban elmondható, hogy azokat kevéssé érte bolygatás, a sírok harmadára jellemző a koporsós temetkezés.

A sírok mellékletei között megfigyelhetőek a vaskések, vascsatok, a női síroknál a gyöngyök, ill. ezüst fülbevalók. A feltárás során 298 sír került elö, elmondható, hogy a temető feltárt, de nem teljes mértékben, mivel egy része túlnyúlt a nyomvonalon. Ettől a temetőtől ca. 60 méterre egy másik avar kori temetőre bukkantak (Kettőshatár II.), ahol 43 sírt tártak fel. A II-es számú temető teljesen feltárt, mivel az összes sír beleesett a nyomvonalba (Mészáros et al, 2006). Az antropológiai és paleopatológiai vizsgálatok során a 263-as sírban talált csontmaradványokon atípusos tbc-re utaló elváltozásokat találtak az SZTE Embertani Tanszék munkatársai. Paleomikrobiológiai doktori kutatásaim lehetőséget teremtettek ennek az esetnek az elemzésére. 
A másik avar kori lelőhely, Hanzélytanya feltárására 1998-ban Medgyesi Pál vezetésével került sor, ahol az avar kori sírok mellett, 10-11. századi temetőrészletre bukkantak a régészek. A Csárdaszállás-Hanzélytanya lelőhelyet 21-es topográfiai számmal látták el, elhelyezkedése Csárdaszállás községtől délkeletre, a mezőberényi országút északi részén található. Korábban, 1958-ban Kovalovszki Júlia már bejárta ezt a területet, akkor két csontvázat találtak a helyszínenEzt követően 1988-ban a tanyát lebontották, ekkor Szénászky Júlia végzett leletmentést. Az avar temető leletanyagában föként gyöngyök, fülbevalók, bronzcsatok voltak (Medgyesi Pál szakmai beszámolója, 2014). A 12-es számú sírban talált egyén esetén atípusos tbc-vel összefüggésbe hozható tünetek kerültek feljegyzésre - paleomikrobiológiai vizsgálataim ennek a leletnek az aDNS vizsgálatát célozták. 


\subsection{Az Árpád-kor}

\subsubsection{Győr-Pósdomb lelőhelyen feltárt Árpád-kori temető}

A Győr-Moson-Sopron megye székhelyének külterülete Pósdomb, ahol az első feltárásokra 1970-ben került sor, Albeker Mária vezetésével, melynek során kora Árpád-kori temető került elő (10-11. század). A régészeti leletek homokbányászat következtében kerültek felszínre, ennek következményeként a lelöhely egy része elpusztult, s így jelentős számú sír megsemmisült (Albeker, 1970, 1970a). A későbbiekben, 1970 és 1973 között Mesterházy Károly vezetésével végeztek újabb ásatásokat. A feltárások eredményeként összesen 217 sír került elő, ez becslések szerint a teljes temető 60\%-át teheti ki (Dávid, 1970, 1971, 1972; Mesterházy, 1974).

A temetőt koporsós temetkezés jellemezte, az eltemetett egyének végtagjait enyhén behajlították. A kora Árpád-kori temetőknek megfelelően a sírok csekély számú mellékletet tartalmaztak, a föként ezüst és bronz köznépi, illetve S-végü karikaékszerek, nyílcsúcsok, bronzpántok, fonott ezüst gyürük, gyöngyök, valamint vaskések, a népesség köznépi temetkezésére utalnak (Albeker 1970; Juhász, 1999). Érmét (Salamon denárát) csupán egyetlen sír esetén tártak fel a régészek (Mesterházy, 1974). A sírokból kis számban kerámiatöredékek is előkerültek.

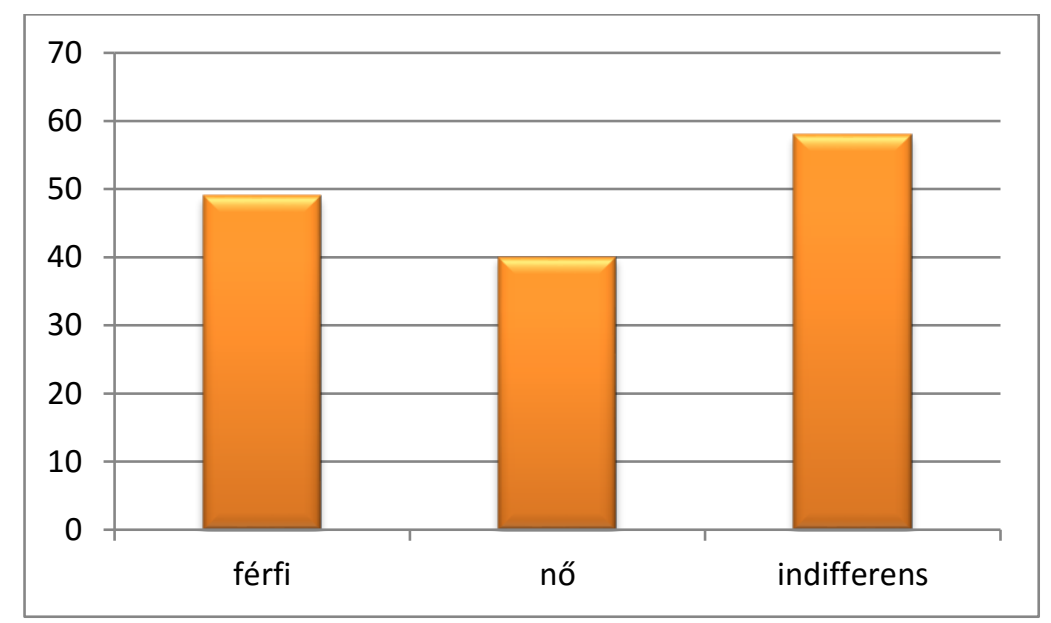

10. ábra: A Pósdomb lelőhelyen feltárt Árpád-kori temető antropológiai vizsgálatokba bevont 147 egyén eloszlása nemek szerint (Juhász, 1999). 
A 217 egyénből 147 került meghatározásra (ez részben a feltárásokat követő elkallódás, részben pedig a megtartási állapot következménye), ahol 58 indifferens, főként gyermekkorosztályba tartozó csontmaradvány, 49 férfi és 40 nő volt elkülöníthető (10. ábra). A csontszéria részletes morfológiai és metrikus közlésére Juhász Eleonóra szakdolgozatában került sor (Juhász, 1999).

A 187. sírból származó egyént kívánjuk részletesebben bemutatni, akinek a gerincoszlopán elöre haladott spondylitis tuberculosa (Pott-gibbus) volt megfigyelhető. Az eset már az antropológiai vizsgálatok kezdetén feljegyzésre került, ennek kapcsán merült fel egy részletesebb morfológiai analízis, illetve a molekuláris biológiai vizsgálatok szükségessége, megerősítve a betegség jelenlétét az Árpád-kori népességek körében. A többi csontváz nem mutatott tuberkulózisra utaló jellegzetes (vagy specifikus) morfológiai elváltozásokat.

A paleomikrobiológiai kutatásokat morfológiai vizsgálatok előzték meg a 187. sírszámú Adultus-Maturus (36-42 éves) férfi esetében, ahol a tipikus Pott-gibbus mellett további tuberkulózisra utaló elváltozásokat lehetett megfigyelni, pl.: egyes bordák a gerinc felöli végükön összecsontosodtak (ld. később: 18. ábra). A vizsgálatok során korai (atípusos) és késői (krónikus) csont-ízületi tbc-s elváltozást, továbbá néhány vázrendszeri fertőzéssel is összefüggésbe hozható egyéb lézió (ún. stressz-faktor) jelenlétét is vizsgáltuk.

Külön köszönettel tartozom a Magyar Természettudományi Múzeum Embertani Tárának, különösen Dr. Pap Ildikó címzetes tárvezetőnek, hogy a vizsgálataimba bevont csontmaradványokat a rendelkezésemre bocsátotta. 


\subsection{A középkor}

\subsubsection{Bácsalmás-Óalmás lelöhely - Egy török hódoltság kori temető}

Bácsalmás a Dél-Alföldön, a Duna-Tisza köze déli részén, Baja és Szabadka között fekszik. A terület legalább az avar kor óta lakott, a török hódoltság kezdetén azonban elnéptelenedett. A kiürült Dél-alföldi régióban, így Bácsalmás területén is hamarosan rácok jelentek meg (Horváth et al, 2006). Bácsalmás-Óalmás lelőhelyen e balkáni eredetű népesség egyik temetőjét fedezték fel a régészek (11. ábra). Az első szakaszban, 1993-ban, 91 sírt tártak fel Wicker Erika irányításával (Wicker, 1999). A feltárások 1995-96-ban Polgár Zoltán és Pintér László vezetésével folytatódtak (82 sír). 1999-re Wicker Erika elkészítette a bácsalmási-óalmási temető elsődleges feltárásának tanulmányát, melynek adataiból kiderül, hogy három generáció emberi maradványait tartalmazza a temető a 16. századtól a 17. század második feléig. A betemetett emberi maradványok zárt közösséget alkotó, vélhetően fokozott endogámiával jellemezhető, többségében rác népességtől származtak (Wicker, 1999). Az ásatások harmadik fázisára 2001-2003-ban került sor, ismét Wicker Erika vezetésével, ekkor újabb 311 sír került felszínre (Lovász et al, 2005b, Wicker, 2006). A feltárások során összesen 481 egyén csontvázmaradványai kerültek elő (Lovász, 2005a; Lovász et al, 2009, 2013). Az embertani szériát a Szegedi Tudományegyetem Embertani Tanszékén tárolják és tanulmányozzák. 


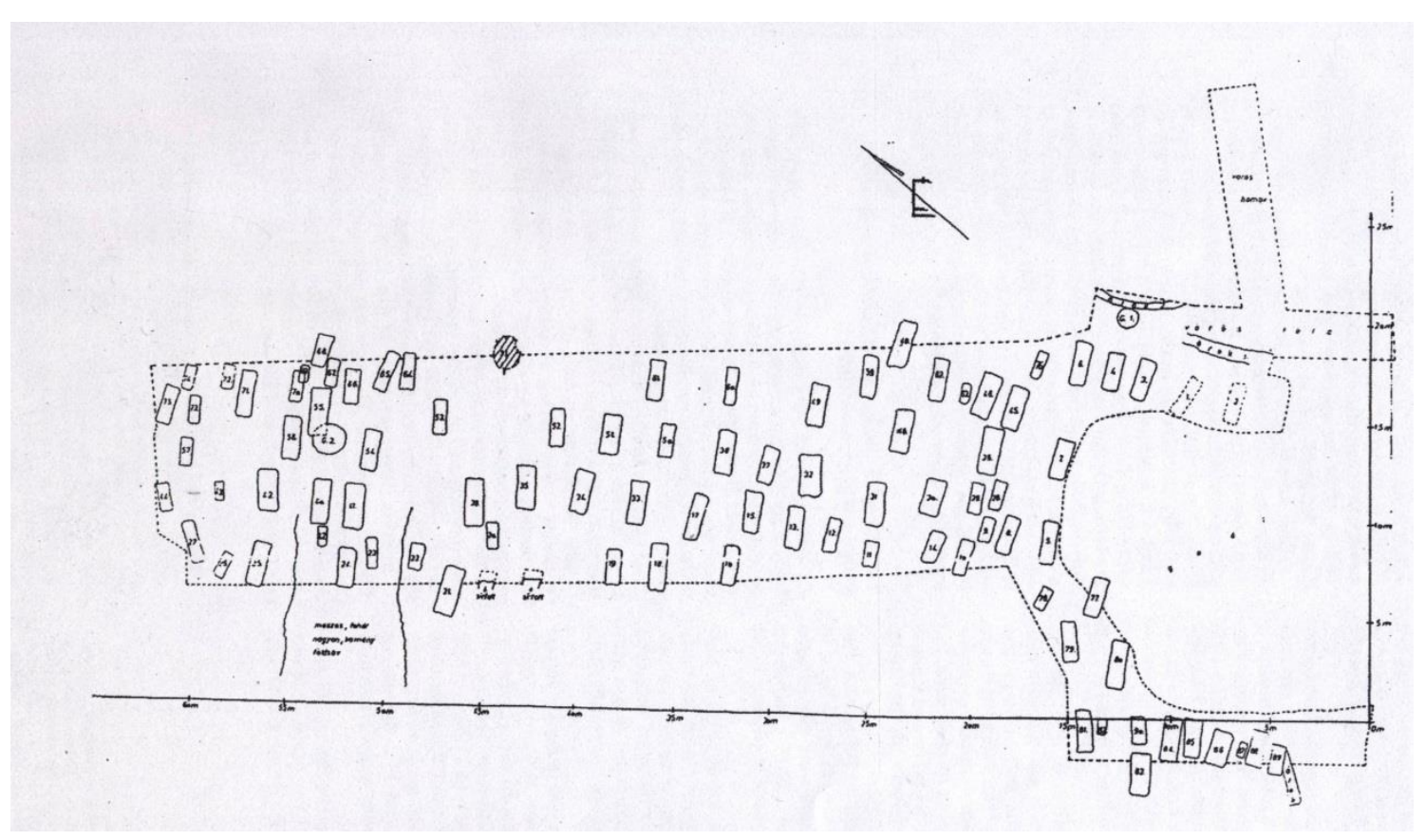

11. ábra: Áttekintő térkép - sírrajz a Bácsalmás-Óalmás középkori temetőről 1993-ból (Wicker et al, 2003).

$\mathrm{Az}$ óalmási rác temetőből származó csontváz-maradványokon már az első morfológiai vizsgálati fázisban azonosítottak súlyos patológiai eseteket, közöttük reumatikus megbetegedéseket és gümőkórral összefüggésbe hozható elváltozásokat is (Horváth et al, 1994; Molnár és Pálfi, 1994; Pálfi et al, 1996, 1997).

A teljes antropológiai feldolgozás paleodemográfiai elemzése során 126 férfit, 113 nőt és 242 nem meghatározható (főként gyermek-korú) nemü egyént azonosítottak (12. ábra). Az embertani széria nagyon gazdag paleopatológiai esetekben (Lovász et al, 2013). Sok olyan fejlődési rendellenesség figyelhető meg a szériában, melyek az endogámia következtében alakulhattak ki ebben a közösségben, ez arra enged következtetni, hogy nem volt jellemző a közösségen kívüli házasság, csökkentve ezzel a genetikai variációk lehetőségét. A csontokon felfedezhető, tbc-re utaló elváltozások két fó csoportba sorolhatók: 1) a korai vagy atípusos elváltozások (endocranialis-, borda-, csigolya- és hosszúcsont elváltozások), 2) krónikus - klasszikus vagy tipikus - tbc-s elváltozások (Lovász, 2015). 


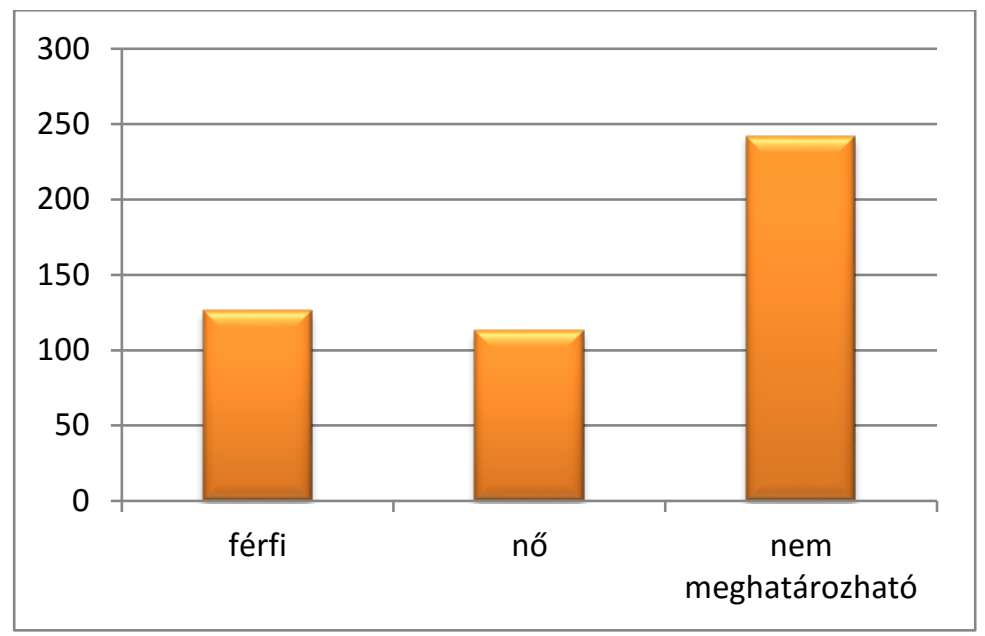

12. ábra: A Bácsalmás-Óalmás lelőhelyen feltárt temető antropológiai vizsgálatokba bevont 481 egyén eloszlása nemek szerint (Lovász, 2015).

A molekuláris vizsgálatokra a teljes széria 481 egyénéből 18 egyén maradványait választottuk ki, köztük morfológiai elváltozásokat mutató és léziómentes eseteket is. Annak érdekében, hogy összehasonlítsuk a kórokozó DNS-ének prezervációját a maradványokban, három helyről vettünk mintát egyénenként: csigolya-, borda- és hosszúcsontok szolgáltak mintavételi helyül. Két esetben (264-es és 483-as sírok esetében) a morfológiai vizsgálatok során lehetséges meningitis-re utaló jeleket figyeltek meg, ezeknél a leleteknél koponya-mintákat is bevontunk. Összességében 56 minta (18 egyénből, 3 minta egyénenként, plusz a koponyacsontok a fentebb említett esetekben) került kiválasztásra az első molekuláris vizsgálat-sorozatra.

A kutatás későbbi fázisában már fogakat is bevontunk a vizsgálatokba, annak érdekében, hogy a kórokozó DNS jelenlétét a maradványokból még nagyobb hatékonysággal kimutathassuk.

\subsubsection{A bácsalmás-óalmási széria jelentősége az archaikus tbc kutatásának szempontjából}

A bácsalmási széria vizsgálata azért kulcsfontosságú a tuberkulózis múltjának kutatása szempontjából, mert nagy elemszámú leletegyüttesen vizsgálható a betegség jelenléte, jó megtartású és aránylag teljes az embertani anyag. A kórokozó jelenlétét olyan késő-középkori/kora újkori demográfiai környezetben tanulmányozhatjuk, ahol a 
betegség aránylag szabadon terjedhetett a nagyobb lélekszámú településeken, az eszközeiben és megközelítésében még középkori szintünek mondható orvoslás alacsony hatékonysága mellett és a korabeli higiénés viszonyok között. További érdekesség a régészeti és antropológiai tanulmányokban felvetett aránylag magas fokú endogámia (és a közösség zárt jellege). Ebben a korszakban a betegség jelenléte már általánosnak mondható, azonban rendkívül érdekes megfigyelésre ad lehetőséget, járványszerü terjedése egy endogám populációban. A feltáró régész, Wicker Erika adataiból tudjuk, hogy ez a rác közösség földművelésből és állattartásból élt, ami az egészségi állapotra kiható nehéz fizikai munkával, ugyanakkor a korszak rendkívül hideg klímája miatt tartós éhezéssel, alultápláltsággal és az ezekből következő egyéb hiánybetegségekkel is járhatott. Mindezt tükrözik a régészeti adatok és az antropológiai-paleopatológiai vizsgálatok eredményei is (Wicker, 2008; Lovász Gabriella PhD-disszertáció, 2015). Fentiek alapján joggal feltételezhető, hogy a megterhelő fizikai munka, a zárt, sürün lakott környezet valamint a kedvezötlen klimatikus helyzettel együttjáró éhezések immunállapotra gyakorolt hatása elősegíthette a népességben a fertőző megbetegedések, így a tuberkulózis terjedését. 


\subsection{Az újkor}

\subsubsection{A váci Fehérek temploma: Sándor Terézia maradványai}

A váci Fehérek temploma 1994-es restaurálásakor bukkantak az Európában is egyedülálló, természetesen mumifikálódott emberi maradványokra. A felújítási munkálatokat végző szakemberek véletlenül fedezték fel a domonkos rendi altemplomba vezető, korábban befalazott bejáratot. Az ajtó újbóli felnyitásakor összesen 265, díszes koporsóban eltemetett, részben vagy teljesen mumifikálódott holttestre bukkantak (Pap et al, 1997; Szikossy et al, 2007). A mumifikálódott emberi maradványokat közel két évtizede a Magyar Természettudományi Múzeum Embertani Tár gondozza.

A Fehérek templomába kezdetben csak egyházi személyek temetkeztek, majd a polgári lakosság is a kriptába kívánta elhelyezni halottait. Az első temetkezések az 1730-es évekre datálhatóak, majd a higiénés viszonyok miatt Mária Terézia és II. József betiltották azokat - a helyiek mégis ide temették szeretteiket ezt követően is. Az utolsó temetkezés 1838-ban történ, majd véglegesen befalaztatták a bejáratot, hogy ezzel a szokásnak véget vessenek. A lakosság meg is feledkezett az altemplomról, olyannyira, hogy 150 évvel később csupán a véletlennek köszönhetően bukkantak a bejáratra (Pap et al, 1997; Szikossy et al, 2007).

A váci altemplomban eltemetett halottak esetében természetes mumifikálódásról beszélünk, mivel semmilyen emberi beavatkozás nem történt a holttestek konzerválása érdekében. A folyamat a környezeti viszonyok szerencsés alakulásának köszönhető. A természetes mumifikálódásnak több fajtája is ismert, minden esetben a környezeti körülmények kulcsfontosságúak, a tartós hideg vagy meleg, a jég vagy a szárazság képes a testet megőrizni a bomlással szemben. A mérsékelt égövön végbemenő természetes mumifikálódás általában a megfelelő mikroklímának, valamint a temetkezés módjának köszönhető.. A kriptában állandó, $10-12^{\circ} \mathrm{C}$-os hőmérséklet volt, mely teljesen független volt a külső hőmérséklettől, állandó, gyenge légmozgás is biztosította a konzerválódást egy szellőzőkürtőn keresztül. A halottakat faforgáccsal borított fenyőkoporsókba helyezték örök nyugalomra, a forgács felszívta a bomlás során keletkező testnedveket, így a testek a rothadás helyett kiszáradtak. A fenyőgyanta 
terpenoid tartalma meggátolta a baktériumok, ill. gombák szaporodását, ezzel hozzájárulva a mumifikálódáshoz (Pap et al, 1997; Szikossy et al, 2007).

Munkánk során Sándor Terézia ${ }^{\dagger \dagger}$ szerzetesnő mumifikálódott holttestéből vett mintán végeztünk molekuláris biológiai vizsgálatokat Mycobacterium tuberculosis aDNS kimutatása és annak tanulmányozása érdekében. A korábban elvégzett CT (computer tomográfia) vizsgálatok, és az azok alapján elvégzett 3D rekonstrukció igazolta a súlyos fokú spondylitis tuberculosa folyamatát (Coqueugniot et al, 2015). A váci múmiákon elvégzett korábbi aDNS vizsgálatok már bizonyították a kiemelkedően magas arányú tbc fertőzöttséget a 18-19. századi népességben (Fletcher et al, 2003b), ezért kértünk lehetőséget arra, hogy kutatásainkba egy váci múmiát is bevonhassunk

\subsubsection{A váci múmiák paleomikrobiológiai jelentősége: tbc az antibiotikumok megjelenése elött}

A tbc paleopatológiai és paleomikrobiológiai kutatása szempontjából egy rendkívül érdekes korszak a váci templomba való temetkezés időszaka. A felfedezett múmiák különleges lehetőséget biztosítanak arra, hogy tanulmányozzuk a kórokozók biológiai maradványait, miközben azt is megfigyelhetjük, miként reagált az emberi szervezet a tuberkulózis-fertőzésre, egy napjainkhoz relatív közel eső, azonban mégis az antibiotikumok megjelenése előtti időszakban. Magyarországon ekkor még nem beszélhetünk átütő erejü iparosodásról, de már megfigyelhetők annak korai jelei. A népesség kezd koncentrálódni a városokban, így a nagyobb népsürüség a 18-19. század fordulójának aránylag szerény higéniés színvonalával párosulva szükségszerüen segítette a fertőző megbetegedések - így a tbc - terjedését. Fletcher és munkatársai 2003-as közleményükben olyan, elgondolkoztatóan magas fertőzöttségi értékekről számolnak be, ami egy évszázaddal előzi meg a 19/20. század fordulójáról ismert

\footnotetext{
† A váci Fehérek templomában eltemetett apáca, aki attól vált ismertté a különböző kiállításokon (pl.: Múmiavilág), hogy testéből kimetszették a szívét, erre a cselekedetre feltételezhetően azért került sor, hogy a szívét szülőföldjében temessék el.

\$ Külön köszönettel tartozom a Magyar Természettudományi Múzeum Embertani Tárának, elsősorban Dr. Pap Ildikó korábbi tárvezetőnek, hogy lehetőséget biztosított számomra a múmia vizsgálatára.
} 
„,morbus hungaricus” morbiditási értékekeit (Fletcher et al, 2003b). Helen Donoghue, Mark Spigelman és munkatársaik 1997 óta folytatnak közös kutatásokat az MTM Embertani Tár munkatársaival. Ezek keretében végzett kutatásaik számos értékes adattal szolgálták a váci múmiagyüjtemény a tbc paleomikrobiológiai kutatását, egyéni esettanulmányokon, teljeskörü fertőzöttségi/paleoepidemiológiai felmérésen vagy akár a legújabb metagenomikai, paleogenomikai vizsgálatokon keresztül. Mára a váci múmiagyüjtemény, kiváló patogén aDNS megtartóképességére tekintettel is, nemzetközileg elismert MTB aDNS referenciagyüjteménnyé vált (Pap et al, 1999; 2001; Fletcher et al, 2003a-b; Donoghue et al, 2011; Chan et al, 2013; Bos et al, 2014; Kay et al, 2015). 


\subsection{Különböző archaikus patogén DNS izolálási metodikák alkalmazása ásatag csontmaradványokon}

Célkitűzéseim között az is szerepelt, hogy régi csontmintákból minél nagyobb hatékonysággal mutassam ki a tuberkulózis ágensének jelenlétét, így olyan metodikák alkalmazását használtam szakirodalmi adatok figyelembevételével, ahol a DNS megőrződése a legnagyobb mértékü és a detektálás sikeressége maximalizálható.

Kezdetben fenol-kloroformos DNS-izolálással (Hochmeister et al, 1991) igyekeztünk elérni a kívánt hatékonyságot (Neparáczki et al, 2011). A fenol-kloroform egészségre ártalmas, ismert rákkeltő hatása, valamint a módszerrel a viszonylag „friss” középkori csontmintákból a vártnál csekélyebb hozamban kapott pozitív eredmények miatt, egy hatékonyabb DNS-kinyerési módszert kezdtünk el alkalmazni. A szilikaalapú metodika hatékonyabbnak bizonyult (Rohland et al, 2009), a módszer hatékonysága a DNS szilikához való kötődésén alapul magas sókoncetráció mellett. A nagyobb mennyiségü DNS-kinyerést azzal is igyekeztünk biztosítani, hogy adott egyénből több helyről vettünk mintát. Szakirodalmi adatok alapján a '90-es években általánosan felhasznált csontminták a bordák, ill. csigolyák voltak, ahol az esetleges morfológiai elváltozás is közvetlenül megfigyelhető. Úgy gondolták, hogy az elváltozás helyén a legnagyobb valószínüségü a kórokozó DNS-maradványának jelenléte (Donoghue et al, 1999; Salo et al, 1994; Taylor et al, 2005). A 2010-es években azonban több tanulmány is megjelent, amely a fogakat preferálta a vizsgálatai során (Nguyen-Hieu et al, 2011; Raoult és Drancourt, 2008), melyek alapján felmerült, hogy a mintavételek során fogakat is alkalmazzunk. Vizsgálataink alátámasztották a cikkek állításait, ennek tapasztalatait összegeztük egy tanulmányban (Pósa et al, 2012a). Az 1. táblázatból világosan kitünik, hogy több kutató kísérletezett alternatív mintavételekkel. 


\begin{tabular}{|c|c|}
\hline publikációk & vizsgált minták $\mathbf{k}^{\S \S}$ \\
\hline Spigelman and Lemma 1993 & $\begin{array}{l}\text { csigolyák, ulnák, koponya fragment, tibia, } \\
\text { femur, bordák }\end{array}$ \\
\hline Salo et al, 1994 & kalcifikálódott tüdő szövet \\
\hline Baron et al, 1996 & csontok \\
\hline Faerman et al, 1997 & fogak, kompakt csontok \\
\hline Braun et al, 1998 & csigolyák \\
\hline Crubézy et al, 1998 & bordák, csigolyák \\
\hline Donoghue et al, 1998 & kalcifikálódott pleuradarab \\
\hline Donoghue et al, 1999 & bordák \\
\hline Dutour et al, 1999 & csontok \\
\hline Faerman et al, 1999 & fogak, hosszúcsontok \\
\hline Zink et al, 1999 & lágyszövet \\
\hline Horáčková et al, 1999 & tibia, femur, csigolya, borda \\
\hline Pálfi et al, 1999 & kalcifikálódott fragmentumok \\
\hline Pap et al, 1999 & lágyszövet \\
\hline Spigelman és Donoghue, 1999 & kalcifikálódott fragmentumok \\
\hline Taylor et al, 1999 & csigolyák \\
\hline Haas et al, 2000 & csontok \\
\hline Zink et al, 2001 & csontok \\
\hline Fletcher et al, 2003a & $\begin{array}{l}\text { múmiák: csontok és lágyszövet maradványok, } \\
\text { kalcifikálódott tüdőszzövet }\end{array}$ \\
\hline Zink et al, 2003 & csontok, lágyszövet \\
\hline
\end{tabular}

§ A publikációkban feltüntett minták megnevezése alapján. 


\begin{tabular}{|c|c|}
\hline publikációk & vizsgált minták \\
\hline Bathurst et al, 2004 & kéztőcsontok \\
\hline Taylor et al, 2005 & $\begin{array}{l}\text { bordák, hosszúcsontok, csigolyák, koponya } \\
\text { fragmentek }\end{array}$ \\
\hline Zink et al, 2005 & csontok \\
\hline Zink et al, 2007 & hosszúcsontok \\
\hline Taylor et al, 2007 & csigolyák, hosszúcsontok, bordák \\
\hline Hershkovitz et al, 2008 & hosszúcsontok \\
\hline Donoghue et al, 2009 & kalcifikálódott tüdőszövet \\
\hline Nerlich et al, 2010 & csontok \\
\hline Lemma et al, 2010 & csontok \\
\hline Neparáczki et al, 2011 & bordák, csigolyák \\
\hline Nguyen-Hieu et al, 2011 & fogak \\
\hline Nicklisch et al, 2012 & hosszúcsontok \\
\hline Pósa et al, 2013 & $\begin{array}{c}\text { bordák, hosszúcsontok, csigolyák, koponya } \\
\text { fragmentek }\end{array}$ \\
\hline
\end{tabular}

1. táblázat: MTB aDNS kimutatásához alkalmazott különböző mintavételi helyek az utóbbi két évtizedből (Pósa et al, 2012a).

Az utóbbi időben egyre inkább a fogakat preferálják a bakteriológiai vizsgálatokra, alkalmasságuk biológiai szempontból könnyen magyarázható, mivel a kórokozók a vérárammal terjednek a gazda szervezetében, így a legjobb vérellátottságú helyeken kumulálódhat a DNS-ük (Zink et al, 2001; Dang La et al, 2008; Donoghue, 2008; Matheson et al, 2009; Nguyen-Hieu et al, 2011). A fogminták használatának hatékonysága és az eredmények megbízhatósága összefügg azzal, hogy az arnylag kompakt struktúra akár több ezer éves eseteknél is megőrizheti a DNS-t, ill. a zománcrétegének köszönhetően védettebb lehet a talajban található egyéb Mycobacterium fajoktól (MOTT) (Raoult és Drancourt, 2008). 


\subsection{A csontmaradványokból történő DNS izolálás}

\subsubsection{A csontminták előkészítése és porítása}

Az elemzésre kiválasztott csontminták egy előzetes tisztításon mennek keresztül, mielőtt a laborhelyiségekbe kerülnek. Már a mintavétel során is a lehető legtisztább módszerekkel nyerjük ki a vizsgálandó anyagot a csontvázakból. A nagytisztaságú laborba való bekerülést megelőzően a mintákat, mintavételi zacskókat és egyéb szükséges használati eszközök minden oldalát 30-30 percig UV megvilágítás alatt sterilezzük. Ezután a kiválasztott csontokat bezacskózva háztartási hipóval kezeljük, majd juttatjuk a labor előterébe, ahol átzacskózzuk a mintát, új, tiszta zacskóba.

Csak ezt követően kerül a pre-PCR labor elökészítő részébe a minta, ahol oldalain 30 percig tartó UV-val történő kezelést hajtunk végre, majd új tiszta zacskóba helyezzük. Hosszúcsontok diafízise esetén ezt követte a ca. $2 \times 3 \mathrm{~cm}$ rész kivágása, csontfürész segítségével. A kivágott, vizsgálatra szánt csontdarabkákról fotódokumentáció készül, mivel a kivett minta a vizsgálatok során felhasználásra kerül, a porítás révén pedig eredeti formája megszünik. Ezután egy ismételt UV-besugárzás, majd a csontok felszínének megtisztítása következik. A fog, ill. a pars petrosa (sziklacsont) külső felszínüket homokfúvó segítségével távolítjuk el - teljes felszínüket megtisztítjuk a szükséges mélységig, így megszabadulva a talajdarabkáktól. Ezt követően új, tiszta zacskóba helyezzük a mintákat, majd ismét 30 percre UV fénnyel való kezelésnek tesszük ki őket, a lehető legjobban minimalizálva az esetleges DNS kontaminációt, végül ismét tiszta zacskóba helyezzük a mintákat.

A csontminták porítása egy Retsch MM301 típusú kétperselyes, golyós őrlőmalomban történik, a csontmalom zárt perselyének köszönhetően a kontamináció kontrollált. A csontok porrá őrlését megelőzve egy mechanikai roncsoláson mennek át, amely munkafolyamat egy előre, hipóval és UV fénnyel kitisztított felületen történik. A munkát megelőzően az eljárás során használt eszközöket 30 perces sterilezésnek tettük ki.

A fog vagy csontmintát vastag alufóliába csomagoljuk, majd az üllöre helyezve a kalapács segítségvel mechanikailag apróbb darabokra törjük. A fóliáról a törmeléket a 
persely őrlötégelyébe töltjük át. Az őrlömalomban egyszerre csak egy mintát porítunk, hogy ne keveredjen és kontamináljon két különböző minta DNS tartalma. A megfelelő szemcsenagyságú csontpor általában eléréséhez 2x25 másodpercen keresztül, 250 Herzes frekvencián őrlünk. Koponyacsontok esetében a 2x25 másodperc helyett 3-4x25 másodpercre is szükség lehet a csont masszívsága miatt. Két minta porítása között DNA-Exitus oldattal töröljük át a tégelyt. Egy másik, elszívás alatt lévő plexiszekrényben öntjük ki a leörölt csontport.

A vékony fóliára öntjük a tégely tartalmát, majd a kanállal egy 15 ml-es eppendorf csőbe $250 \mathrm{mg}$ csontport mérünk, a maradék csontport Greiner csőbe helyezzük, melyet $+4^{\circ} \mathrm{C}$-os hütőben tárolunk az újabb felhasználásig. Két minta őrlése között a munkafelületet hipóval, ill. a fémeszközöket DNA-Exitus oldattal kezeljük. Ezt követően a tégelyt nagy körültekintéssel tisztítjuk.

A porítás tisztaságának ellenőrzése érdekében egy golyós kontrollt alkalmazunk, ezt hidroxilapatitos porítással végezzük. Az utolsó minta porítását követően hidroxilapatitot öntünk a tégelybe, majd a minták porításával megegyező módon őröljük a kontollt.

\subsubsection{A csontmintákból történő DNS izolálás folyamata}

A csontokból történő DNS extrakciót a Rohland és munkatársai által kidolgozott protokollnak megfelelően végeztük, kisebb módosításokkal (Rohland et al, 2009). Munkánk során három paralell vizsgálatot végeztünk.

1. $250 \mathrm{mg}$ csontporhoz $5 \mathrm{ml}$ 0,5 M-os EDTA-t és $20 \mu \mathrm{l} 20 \mathrm{mg} / \mathrm{ml}$-es proteináz K-t adtunk, majd vortexelést követően $40^{\circ} \mathrm{C}$-on inkubáltuk folyamatos vertikális kevertetés mellett egy éjszakán át. Ezzel a lépéssel eltávolíthatók a fehérjék az extraktumból.

2. A mintákat 2 percig 5.000 g-vel centrifugáltuk, majd a felülúszót megtartott új csőbe helyezve.

3. A felülúszóhoz $2,5 \mathrm{ml}$ binding puffert és $100 \mu \mathrm{l}$ szilika szuszpenziót adtunk. 
4. Vertikális kevertetés során 3 órán keresztül szobahőmérsékleten inkubáltuk az extraktumot.

5. 2 perc alatt 5.000 g-vel centrifugáltuk a mintákat.

6. Leöntöttük és eldobtuk a felülúszót.

7. $\quad 1.000 \mu \mathrm{l}$ binding puffert adtunk a szilika pellethez, majd szuszpendáltuk, ezt követően átöntöttük 2 ml-es tiszta csövekbe a mintákat.

8. 15 másodpercig 16.000 g-vel centrifugáltuk a mintákat.

9. A felülúszót eltávolítottuk és $500 \mu$ washing puffert adtunk a mintákhoz, majd szuszpendáltuk és 15 másodpercig 16.000 g-vel centrifugáltuk. Ezt a lépést megismételtük.

10. A felülúszót eltávolítottuk a mintákról. 15 másodperc alatt 16.000 g-vel centrifugáltuk és eltávolítottuk a maradék folyadékot, a szilika pelletet egy órán keresztül szárítottuk szobahőmérsékleten.

11. A mintákra $200 \mu \mathrm{TE}$ puffert pipettáztunk és pipetta vagy vortex segítségével szuszpendáltuk.

12. 5 percig $60^{\circ} \mathrm{C}$-on inkubáltuk az izolátumokat.

13. A csövek tetejére szilikon pasztát helyeztünk és 2 perc alatt 16.000 g-vel centrifugáltuk a mintákat.

14. A felülúszót friss, tiszta 1,5 ml-es LoBind Eppendorf csövekbe helyeztük.

15. A minták a felhasználásnak megfelelően tárolhatók $\left(-20^{\circ} \mathrm{C}\right.$-os fagyasztóban vagy $4^{\circ} \mathrm{C}$-os hütőben). 
Izolálás során alkalmazott oldatok:

$\operatorname{EDTA}(0,5 \mathrm{M} ; \mathrm{pH}=8,200 \mathrm{ml})$

$100 \mathrm{ml} \mathrm{ddH_{2 } \mathrm { O } - \text { ben }}$

$37,22 \mathrm{~g}$

$\mathrm{NaOH}$ pellettel beállítjuk a $\mathrm{pH}=8$

$\mathrm{dd}_{2} \mathrm{O}$

200 ml-ig

Tris/HCl (0,5M; pH=8; $200 \mathrm{ml})$

$100 \mathrm{ml} \mathrm{ddH_{2 } \mathrm { O } - \text { ben }}$

$12,11 \mathrm{~g}$

$\mathrm{HCl}$-el beállítjuk a $\mathrm{pH}=8$

$\mathrm{ddH}_{2} \mathrm{O}$

$200 \mathrm{ml}-\mathrm{ig}$

TE puffer $(\mathrm{pH}=8 ; 100 \mathrm{ml})$

$10 \mathrm{mM}$ Tris/HCl $(\mathrm{pH}=8)$

$2 \mathrm{ml} \mathrm{a} 0,5 \mathrm{M}$ tris $/ \mathrm{HCl}(\mathrm{pH}=8)$

$1 \mathrm{mM}$ EDTA $(\mathrm{pH}=8)$

$200 \mu 1$ a 0, 5M EDTA (pH=8) oldatból

$\mathrm{ddH}_{2} \mathrm{O}$

100 ml-ig

Nátrium-acetát (3M; $\mathrm{pH}=5,2 ; 50 \mathrm{ml})$

nátrium-acetát

$12,3 \mathrm{~g}$

37\%-os HCl-dal beállítjuk a pH-t

$\mathrm{ddH}_{2} \mathrm{O}$

$50 \mathrm{ml}-\mathrm{ig}$

Binding puffer (50 ml)

$5 \mathrm{M} \mathrm{GuSCN}$

$29,84 \mathrm{~g}$

300 mM nátrium-acetát $(\mathrm{pH}=5,2)$

$5 \mathrm{ml} \mathrm{3M}$ nátrium-acetát $(\mathrm{pH}=5,2)$

$\mathrm{ddH}_{2} \mathrm{O}$

$50 \mathrm{ml}-\mathrm{ig}$ 
Washing puffer $(200 \mathrm{ml})$

$\begin{array}{ll}125 \mathrm{mM} \text { NaCL } & 1,46 \mathrm{~g} \mathrm{NaCl} \\ 10 \mathrm{mM} & 0,24 \mathrm{~g} \text { Tris } \\ 1 \mathrm{mM} \text { EDTA }(\mathrm{pH}=8) & 400 \mu 1 \mathrm{a} 0,5 \mathrm{M} \text { EDTA }(\mathrm{pH}=8) \text { oldatból } \\ \mathrm{ddH}_{2} \mathrm{O} & 100 \mathrm{ml}-\mathrm{ig} \\ \text { autoklávozás után } & \\ \text { EtOH } & 200 \mathrm{ml}-\mathrm{ig}\end{array}$

Szilika szuszpenzió

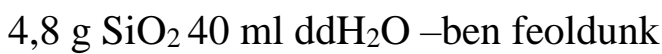

1 órán keresztül üllepítjük

39 ml-nyit egy új csőbe pipettázunk, majd 4 órán keresztül üllepítjük

35 ml felülúszót kidobunk

$48 \mu \mathrm{l} 30 \%$-os $\mathrm{HCl}-\mathrm{t}$ adunk a $4 \mathrm{ml}$ pellethez

óvatosan vortexeljük

$4^{\circ} \mathrm{C}$-on 500 ul aliqout-ot tárolunk 


\subsubsection{A baktérium DNS amplifikálás folyamata}

A DNS extrakciót követően ellenőriztük, hogy sikeresen végbement-e a kivonás és rendelkezésünkre áll-e a keresett ősi bakteriális DNS. Ezt PCR analízissel végeztük el, IS6110R, IS6110F és IS6110intR, IS6110intF primereket alkalmaztuk, mivel ezek a legáltalánosabban alkalmazott primerek a Mycobacterium aDNS vizsgálata során (Eisenach et al, 1990; Taylor et al, 1996). Avizsgálatok során pozitív kontroll nem alkalmaztunk, mivel Mycobacterium aDNS vizsgálatok esetében ez az elfogadott (Zink et al, 2001; 2003).

Az amplifikációhoz hot-start PCR-t alkalmaztunk. A PCR reakció elegy a

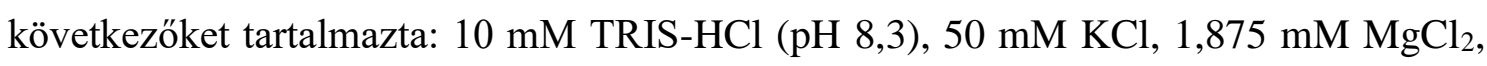
$200 \mu \mathrm{M}$ mindegyik dezoxinukleotid trifoszfátból, $0.5 \mu \mathrm{M}$ mindkét primerböl, $0.1 \mathrm{mg} / \mathrm{ml}$ BSA-t, 0.05 U/ $\mu 1$ AmpliTaqGold-ot (Amplied Biosystems, Foster City, CA, USA) és 2 $\mu 1$ a kinyert DNS-ből, a végső térfogat $20 \mu 1$.

A PCR program az alábiak szerint történt:

- denaturálás: $\quad 95^{\circ} \mathrm{C} \quad 5$ perc

- denaturálás: $\quad 95^{\circ} \mathrm{C} \quad 1$ perc

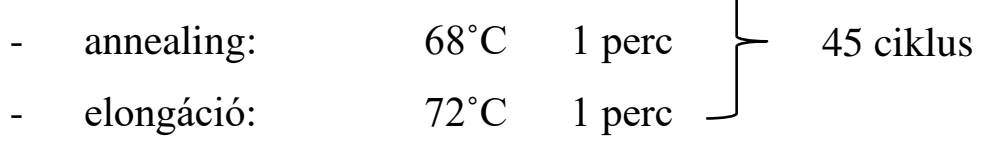

- $\quad$ végső elongáció: $\quad 72^{\circ} \mathrm{C} \quad 8$ perc

Nested PCR:

- denaturálás: $\quad 95^{\circ} \mathrm{C} \quad 5$ perc

- denaturálás: $\quad 95^{\circ} \mathrm{C} \quad 1$ perc

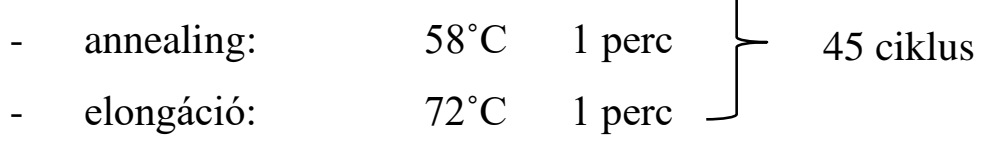

- $\quad$ végső elongáció: $\quad 72^{\circ} \mathrm{C} \quad 8$ perc

Az Mycobacterium specifikus szekvencia jelenlétét a reakcióban 3\%-os agaróz gélen ellenőriztük etidium-bromidos festéssel. 
A Mycobacterium tuberculosis DNS-ének amplifikálása során felhasznált primerek:

\begin{tabular}{|c|c|c|c|c|}
\hline Target & Szekvencia & Primer & $\begin{array}{c}\text { Termék } \\
\text { (bp) }\end{array}$ & Referencia \\
\hline MTBC IS6110 & $\begin{array}{l}\text { 5'-CCT GCG AGC GTA GGC GTC GG-3' } \\
\text { 5'-CTC GTC CAG CGC CGC TTC GG-3' }\end{array}$ & $\begin{array}{l}\text { IS6110R } \\
\text { IS6110F }\end{array}$ & 123 & $\begin{array}{l}\text { Eisenach et al, } \\
1990\end{array}$ \\
\hline $\begin{array}{l}\text { MTBC IS6110 } \\
\text { internal }\end{array}$ & $\begin{array}{l}\text { 5'-TCG GTG ACA AAG GCC ACG TA-3' } \\
\text { 5'-TTC GGA CAA CCA GCA CCT AA-3' }\end{array}$ & $\begin{array}{l}\text { IS6110intR } \\
\text { IS6110intF }\end{array}$ & 92 & Taylor et al, 1996 \\
\hline
\end{tabular}

Coros és munkatársai 2008-ban kimutatták, hogy az IS6110 szekvencia a Mycobacterium smegmatis-ra is jellemző (Coros et al, 2008). A paleomikrobiológiai kutatás nemzetközi iskolái hosszú éveken át nem tartották relevánsnak a M. smegmatis előfordulásának lehetőségét régi emberi csontokban, így a 2010-es években a paleomikrobiológiában a hagyományos módszerekkel folytatódott az tbc archaikus DNS kimutatása, a korábbiaknál is körültekintőbb DNS-mentes laboratóriumi környezetben és alaposabb minta-kiválasztás alkalmazásával. Müller és munkatársai 2015-ben és 2016-ban jelentették meg tanulmányaikat arról, hogy további, nem tuberkuloid Mycobacterium (MOTT) is tartalmazhatnak IS6110-et, amelyek a talajban előfordulhatnak, és így bekerülhetnek a csontokba (Müller et al, 2015; 2016).

A kutatásainkban alkalmazott mintavételi megoldások, és a komplementer morfológiai és paleomikrobiológiai elemzés együttesen azonban megfelelő garanciát nyújtanak e specifitási probléma kezelésére.

\subsection{Egyéb DNS-alapú vizsgálati módszerek - Spoligotyping}

A ,spoligotyping” kifejezés egy mozaikszó, mely a Spacer oligonucleotide typing kifejezésből származik (Aranaz et al, 1996). A technika megkülönbözteti a $M$. tuberculosis törzseket, megadja a törzs identitását, rendkívül gyors módszer. A korábban, IS6110 és/vagy IS1081 primerekkel elvégzett amplifikáció során pozitív eredmények esetében alkalmazták (Zink et al, 2003). A M. tuberculosis komplex genotipizálására alkalmas, a PCR-en alapuló módszert ca. 20 évvel ezelőtt standardizálták Kamerbeek és munkatársai (Kamerbeek et al, 1997). A módszer 
lényege, hogy a $M$. tuberculosis genomjában magas a polimorfikus direkt repeat-ek (DR) száma (Rothschild et al, 2001; Filliol et al, 2006; Gori et al, 2005; Suresh et al, 2006; Donoghue, 2008; Driscoll, 2009). Az PCR során a primerek a DR régióban 43 egyedi spacer régiót amplifikálnak, amelyek minden egyes DR lókusz között megtalálhatóak (Aranaz et al, 1996; Rotschild et al, 2001; Donoghue, 2008). Az alkalmazott két primer a Dra és Drb, elöbbi biotinnal jelölt, a folyamat során a teljes DR régiót amplifikálják (Kamerbeek et al, 1997; Zink et al, 2003). A PCR termék hibridizál az immobilizált spacer oligonukleotidokhoz, melyek ismert szekvenciájúak. Az oligonukleotikok kovalensen kapcsolódnak az aktivált membránhoz a parallel helyeken. A membránt inkubálják szteptavidin-peroxidázzal vagy szteptavidin-alkalifoszfatázzal, mely megköti a biotin-jelölt DNS terméket. A detektálás kemilumineszcenciával vagy kemifluoreszcenciával történik, a peroxidáz vagy az alkalikus-foszfatáz a szteptavidin katalázon egy olyan reakciót eredményez, amely fluoreszcens fényt emittál. A folyamat autoradiográfiával tehető láthatóvá (Zink et al, 2003; de Boer et al, 2002; Donoghue, 2008, 2011).

A spoligotyping esetén két referenciatörzset különböztetünk meg, a $M$. tuberculosis $\mathrm{H}_{37} \mathrm{Rv}$ (spacerek elhelyezkedése: 39, 40, 41 és 43), és a Pasteur-törzset ( $M$. bovis BCG P3 a spacerek elhelyezkedése: 20, 21, és a 33-36 között), ezekhez viszonyítjuk a többi mintázatot (26. ábra). A 39, 40, 41 és a 43-as spacerek jelenléte kizárja annak lehetőségét, hogy modern M. bovis lenne jelen (Aranaz et al, 1996; Kamerbeek et al, 1997; Rotschild et al, 2001, de Boer et al, 2002, Donoghue, 2011). 
A technika alkalmazható klinikai mintákon is, sokkal érzékenyebb, mint a ZiehlNeelsen (ZN) festés és nagy elönye, hogy a fragmentált DNS estében is müködik, továbbá a formalinkezelt minták esetén is sikeresen alkalmazzák (de Boer et al, 2004; Namouchi et al, 2008). Nagy előnye, hogy az amplifikáció közvetlenül használható a hibridizációhoz, a különböző törzsek eltérő mintázatot adnak, így jó elkülönítést tesz lehetővé a $M$. tuberculosis komplexnél, mivel csak a komplex tagjait tartalmazza (Kamerbeek et al, 1997). A korai kutatások során rendkívül kedvelt vizsgálati módszer volt, hiszen az akkori technológiai fejlettség lehetőséget adott a kísérlet ismételhetőségére. Folyamatosan fejlesztették a nagy áteresztőképességü vizsgálatok felé, hogy alkalmazhatóvá váljon a tömeges molekuláris epidemiológiai vizsgálatok során. Minden előnye ellénre több nehézségbe ütközött az alkalmazása (pl.: a müszerek és membránok nehéz beszerezhetősége), és azt is felismerték, hogy a metódus csak a nagy törzscsaládok között képes különbséget tenni (Discoll, 2009). A módszer további hátránya, hogy aránylag kevés filogenetikai információt nyújt (Abadia et al, 2011; Müller et al, 2014; Nerlich et al, 2009).

Később, az egyre modernebb vizsgálati módszerek mellett, a spoligotyping más hátrányát is felismerték. A klasszikus spoligotyping vizsgálatok nem voltak teljes mértékben megbízhatóak, bebizonyosodott, hogy az alkalmazott membránok minősége nem mindig megfelelő, a DNS-prezerváció problémái miatt a spoligotyping mintázata esetenként csak kis lefedettséget mutatott, mely nem adott egyértelmü értékelésre lehetőséget. Ez a probléma azonban minden olyan esetben fennáll, ahol a mikrokörnyezeti hatások degradáltságot okoztak a DNS-ben 


\section{Eredmények és megvitatás}

\subsection{Neolitikum}

Alsónyék-Bátaszék neolit temető 13-as sírcsoportjának döntő hányadát, a 38 humán csontvázmaradványát bevontuk a makroszkópos morfológiai és paleomikrobiológiai vizsgálatokba. A vizsgálat elsődleges aktualitását adó 4027-es sírszámú Pott-gibbus-os eset (13. ábra) mellett számos más egyén ( $\mathrm{n}=17)$ mutatott atípusos tbc-elváltozásra (15. ábra) utaló csonttani tüneteket (2. táblázat).

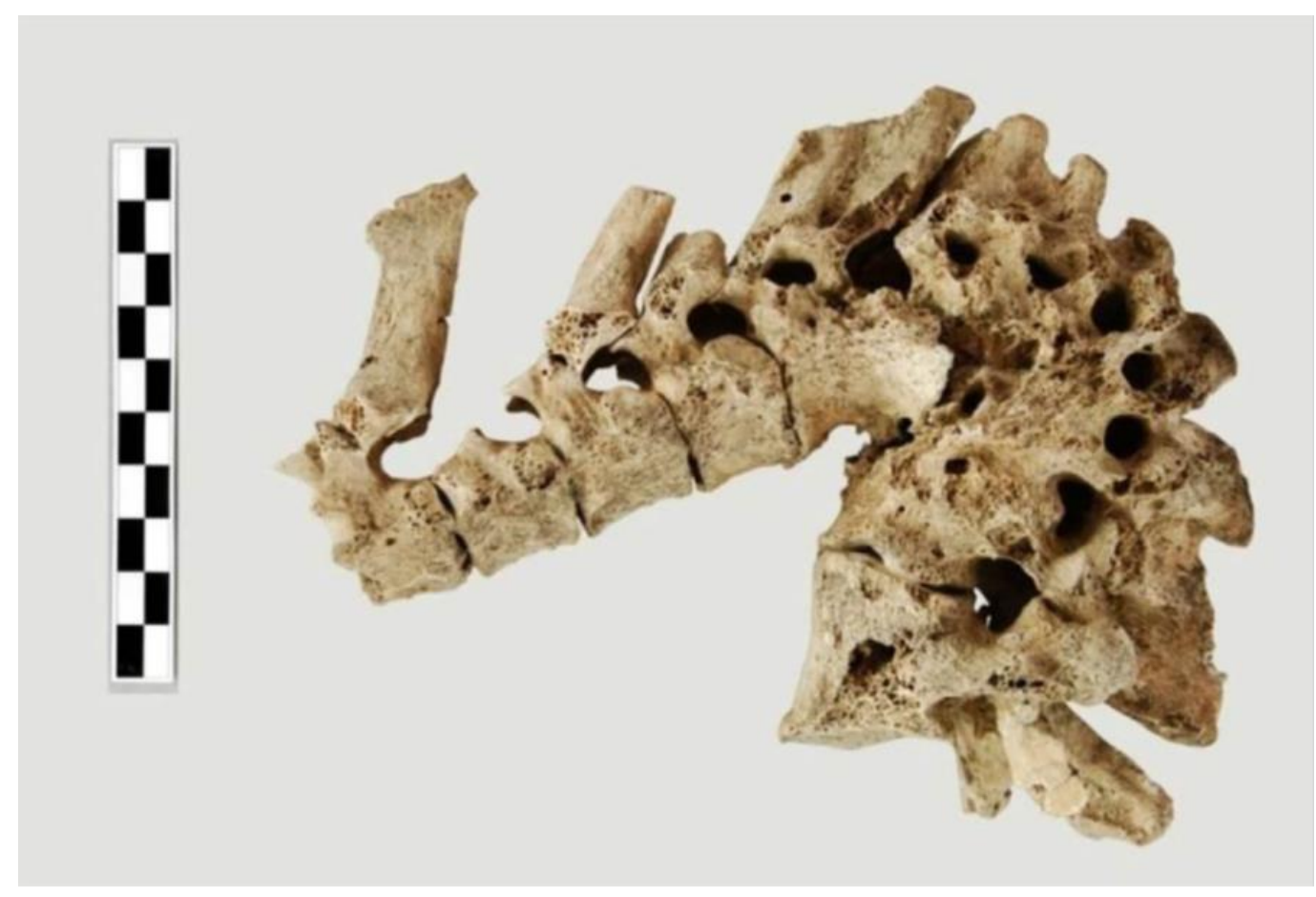

13. ábra: Súlyos Pott-gibbus-os eset az Alsónyék-Bátaszék lelőhely 4027-es sírjából (Köhler et al, 2012; Pósa et al, 2015b, 2016a).

Fontos megjegyeznünk, hogy a vizsgált maradványok között szerepeltek „morfológiailag negatív”, azaz olyan vázmaradványok is, amelyek egyáltalán nem mutattak a betegségre jellemző elváltozásokat $(\mathrm{n}=21)$. A vizsgált 38 egyénből 5-nél (13\%) kaptunk pozitív molekuláris eredményt baktérium DNS vizsgálata során tesztelt IS6110 repetitív elemre (14. ábra). Érdekes és fontos adat, hogy az öt MTBC aDNS pozitív esetböl egynél (ID 422) nem volt látható nyoma patológiás elváltozásnak. 


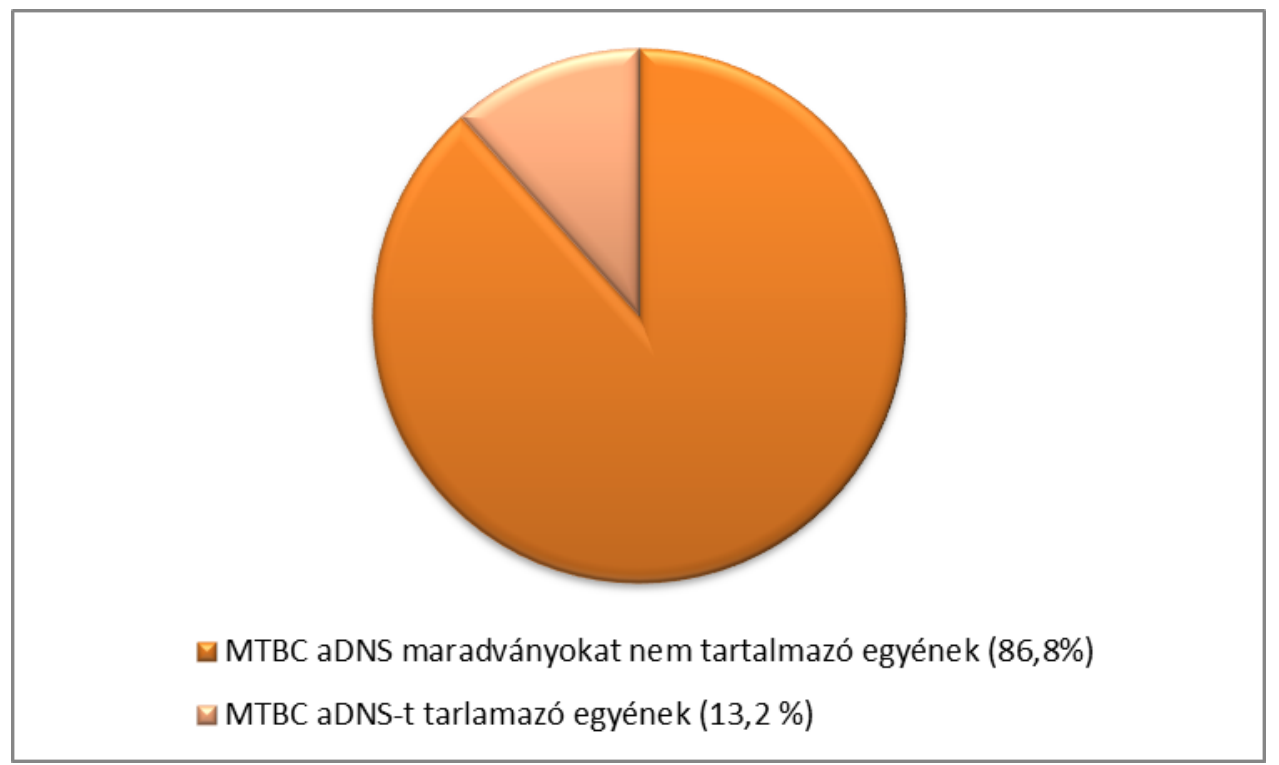

14. ábra: A molekuláris vizsgálatokba bevont, lengyeli kultúrából származó sírcsoport aDNS vizsgálattal kimutatható fertőzöttségének aránya.

Összesen hat lelet esetében kaptunk pozitív eredményt spoligotyping vizsgálat során (2. táblázat). A spoligotyping vizsgálatunk során azonban a mintázatok nagyon szórványos lefedettséget mutattak a DNS nagymértékü degradációja miatt, így ezeket az eredményeket nem lehetett felhasználni további törzsi tipizálásához. Spoligotyping elemzésünket így kiegészítő vizsgálatként kezeltük, annak bizonyítására, hogy a MTBC aDNS valóban jelen volt az IS6110 pozitív mintákban. Ezért az olyan esetek, melyek csak spoligotyping vizsgálat során mutattak pozitív eredményt (ID 801, 813, 815), nem szerepelnek a molekulárisan tbc pozitív esetek között.

\begin{tabular}{|c|c|c|c|c|c|c|}
\hline Esetszám & $\begin{array}{c}\text { Elhalálozási } \\
\text { kor }\end{array}$ & Sexus & Morfológiai lézió & $\begin{array}{l}\text { Minta } \\
\text { típusa }\end{array}$ & $\begin{array}{l}\text { IS6110 } \\
\text { int }\end{array}$ & $\begin{array}{c}\text { Spoligo- } \\
\text { typing }\end{array}$ \\
\hline \multirow{2}{*}{256} & \multirow{2}{*}{$6-7$} & & \multirow{2}{*}{$\begin{array}{l}\text { endocranialis elváltozás, } \\
\text { borda periostitis, } \\
\text { hosszúcsont periostitis }\end{array}$} & fog & - & Sp38 \\
\hline & & & & tibia & + & n.d. \\
\hline \multirow{2}{*}{396} & \multirow{2}{*}{$1-2$} & & \multirow[t]{2}{*}{ 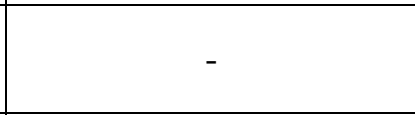 } & fog & - & n.d. \\
\hline & & & & radius & - & n.d. \\
\hline \multirow{2}{*}{398} & \multirow{2}{*}{ n.d. } & \multirow{2}{*}{ n.d. } & \multirow{2}{*}{$\begin{array}{l}\text { periostitis midkét tibián } \\
\text { és fibulán }\end{array}$} & fog & - & - \\
\hline & & & & femur & - & - \\
\hline \multirow{2}{*}{422} & \multirow{2}{*}{$11-12$} & & \multirow{2}{*}{-} & fog & - & Sp7 \\
\hline & & & & femur & + & Sp43 \\
\hline
\end{tabular}




\begin{tabular}{|c|c|c|c|c|c|c|}
\hline Esetszám & $\begin{array}{c}\text { Elhalálozási } \\
\text { kor }\end{array}$ & Sexus & Morfológiai lézió & $\begin{array}{l}\text { Minta } \\
\text { típusa }\end{array}$ & $\begin{array}{l}\text { IS6110 } \\
\text { int }\end{array}$ & $\begin{array}{c}\text { Spoligo- } \\
\text { typing }\end{array}$ \\
\hline \multirow{2}{*}{423} & \multirow{2}{*}{$23-59$} & \multirow{2}{*}{ férfi } & \multirow{2}{*}{-} & $\begin{array}{c}\text { koponya } \\
\text { fragmentum }\end{array}$ & - & n.d. \\
\hline & & & & $\begin{array}{c}\text { koponya } \\
\text { fragmentum }\end{array}$ & - & n.d. \\
\hline \multirow{2}{*}{782} & \multirow{2}{*}{$20-23$} & & \multirow{2}{*}{-} & fog & - & n.d. \\
\hline & & & & femur & - & n.d. \\
\hline \multirow{2}{*}{783} & \multirow{2}{*}{$40-59$} & \multirow{2}{*}{ férfi } & \multirow{2}{*}{$\begin{array}{l}\text { enyhe hosszúcsont } \\
\text { periostitis }\end{array}$} & fog & - & n.d. \\
\hline & & & & femur & - & n.d. \\
\hline \multirow{2}{*}{784} & \multirow{2}{*}{$6-8$} & & \multirow{2}{*}{ endocranialis elváltozás } & fog & - & n.d. \\
\hline & & & & femur & - & n.d. \\
\hline \multirow{2}{*}{785} & \multirow{2}{*}{$35-45$} & \multirow{2}{*}{ nö } & \multirow{2}{*}{-} & fog & - & n.d. \\
\hline & & & & femur & - & n.d. \\
\hline \multirow[b]{2}{*}{791} & \multirow[b]{2}{*}{$40-50$} & \multirow[b]{2}{*}{ férfi } & \multirow{2}{*}{$\begin{array}{c}\text { periostitis } \\
\text { hosszúcsontokon, } \\
\text { csigolyatörés }\end{array}$} & fog & - & n.d. \\
\hline & & & & femur & + & $\mathrm{Sp} 4$ \\
\hline \multirow{2}{*}{792} & \multirow{2}{*}{$50-59$} & \multirow{2}{*}{ férfi } & \multirow[t]{2}{*}{$x_{-1}$} & fog & - & n.d. \\
\hline & & & & femur & - & n.d. \\
\hline \multirow{2}{*}{793} & $8-9$ & & - & fog & - & n.d. \\
\hline & $8-9$ & & - & femur & - & n.d. \\
\hline 704 & $16-18$ & & & fog & - & n.d. \\
\hline 194 & $16-18$ & & - & femur & - & n.d. \\
\hline 796 & $23-26$ & nö & $\ldots$ & fog & - & n.d. \\
\hline 190 & $2 \mathrm{~J}-2 \mathrm{O}$ & no & - & femur & - & n.d. \\
\hline 797 & $10-12$ & & ondocranialis elváltozás & fog & - & n.d. \\
\hline 191 & $10-12$ & & enaocrantalts ervaltozas & femur & - & n.d. \\
\hline 708 & $50-60$ & fórfi & 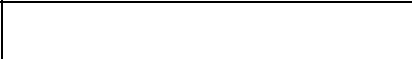 & fog & - & n.d. \\
\hline 198 & $50-60$ & tert1 & - & femur & - & n.d. \\
\hline 709 & $35-45$ & nö & - & fog & - & n.d. \\
\hline 199 & $3 J-4 J$ & 110 & - & femur & - & n.d. \\
\hline 800 & $40-45$ & nö & - & fog & - & n.d. \\
\hline 800 & $40-43$ & no & 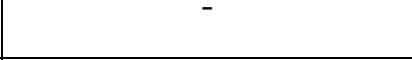 & femur & - & n.d. \\
\hline & & & bilateralis cribra & fog & - & n.d. \\
\hline 801 & $3-5$ & & $\begin{array}{c}\text { orbitalia és borda } \\
\text { periostitis }\end{array}$ & femur & - & Sp30 \\
\hline 802 & 15.18 & & 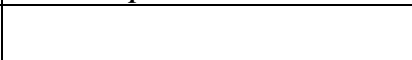 & fog & - & n.d. \\
\hline 802 & $15-18$ & & - & femur & - & n.d. \\
\hline & $25-35$ & & & fog & - & n.d. \\
\hline 803 & $25-35$ & fert1 & - & femur & - & n.d. \\
\hline & & & endocranialis elváltozás, & fog & - & n.d. \\
\hline 804 & $7-8$ & & $\begin{array}{c}\text { csigolya } \\
\text { hypervascularisatio }\end{array}$ & femur & - & n.d. \\
\hline 805 & $30-40$ & nö & endocranialis elváltozás, & fog & - & n.d. \\
\hline
\end{tabular}




\begin{tabular}{|c|c|c|c|c|c|c|}
\hline & & & periostits a tibiákon & femur & - & n.d. \\
\hline Esetszám & $\begin{array}{c}\text { EIhalálozási } \\
\text { kor }\end{array}$ & Sexus & Morfológiai lézió & $\begin{array}{l}\text { Minta } \\
\text { típusa }\end{array}$ & $\begin{array}{c}\text { IS6110 } \\
\text { int }\end{array}$ & $\begin{array}{c}\text { Spoligo- } \\
\text { typing }\end{array}$ \\
\hline \multirow{2}{*}{808} & \multirow{2}{*}{$35-45$} & \multirow{2}{*}{ férfi } & \multirow{2}{*}{ - } & fog & - & n.d. \\
\hline & & & & femur & - & n.d. \\
\hline \multirow{2}{*}{809} & \multirow{2}{*}{$50-55$} & \multirow{2}{*}{ férfi } & \multirow{2}{*}{-} & fog & - & n.d. \\
\hline & & & & femur & - & n.d. \\
\hline \multirow{2}{*}{810} & \multirow{2}{*}{$35-45$} & \multirow{2}{*}{ nő } & \multirow{2}{*}{ - } & fog & - & n.d. \\
\hline & & & & femur & - & n.d. \\
\hline \multirow{2}{*}{811} & \multirow{2}{*}{$23-26$} & & \multirow{2}{*}{$\begin{array}{c}\text { endocranialis elváltozás, } \\
\text { cribra cranii, cribra } \\
\text { orbitalia, hosszú csont } \\
\text { periostitis }\end{array}$} & fog & - & n.d. \\
\hline & & & & femur & + & - \\
\hline \multirow[b]{2}{*}{812} & \multirow[b]{2}{*}{$20-25$} & \multirow[b]{2}{*}{ nő } & \multirow{2}{*}{\begin{tabular}{|c|} 
csigolya \\
hypervascularisatio, \\
súlyos hosszúcsont \\
periostitis
\end{tabular}} & fog & - & - \\
\hline & & & & tibia & - & - \\
\hline \multirow{2}{*}{813} & \multirow{2}{*}{$25-35$} & \multirow{2}{*}{ férfi } & \multirow{2}{*}{$\begin{array}{c}\text { endocranialis elváltozás, } \\
\text { cribra orbitalia, } \\
\text { periostits a tibián }\end{array}$} & fog & - & - \\
\hline & & & & femur & - & $\begin{array}{c}\text { Sp6, 10, } \\
11,38 \\
\end{array}$ \\
\hline \multirow[t]{2}{*}{815} & \multirow[t]{2}{*}{ n.d. } & \multirow[t]{2}{*}{ n.d. } & \multirow[t]{2}{*}{-} & fog & - & $\begin{array}{c}\text { Sp14, 19, } \\
22,23\end{array}$ \\
\hline & & & & femur & - & - \\
\hline \multirow{2}{*}{817} & \multirow{2}{*}{$25-35$} & \multirow{2}{*}{ nő } & 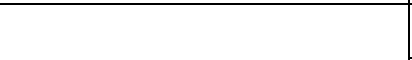 & fog & - & n.d. \\
\hline & & & - & femur & - & n.d. \\
\hline 818 & $40-59$ & nő & endocranialis elváltozás, & femur & - & n.d. \\
\hline 818 & $40-59$ & no & hosszúcsont periostitis & femur & - & n.d. \\
\hline 819 & $23-30$ & férfi & $\begin{array}{l}\text { periostitis a fibulán és a } \\
\text { femuron, csigolya }\end{array}$ & femur & - & - \\
\hline & & & hypervascularisatio & femur & - & - \\
\hline 853 & 4050 & n" & 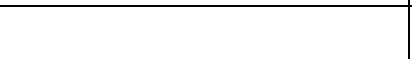 & fog & - & n.d. \\
\hline 853 & $40-50$ & no & - & tibia & - & n.d. \\
\hline 4011 & $25-28$ & férfi & $\begin{array}{c}\text { cribra orbitalia, } \\
\text { periostitis a femuron, }\end{array}$ & fog & - & n.d. \\
\hline & & & tibián és fibulán & femur & - & n.d. \\
\hline 4012 & $25-30$ & nö & - & fog & - & n.d. \\
\hline 4012 & $25-30$ & no & - & tibia & - & n.d. \\
\hline & & & $\begin{array}{l}\text { endocranialis elváltozás, } \\
\text { cribra orbitalia, borda }\end{array}$ & fog & + & - \\
\hline 4027 & $30-40$ & férfi & $\begin{array}{c}\text { periostitis, hosszúcsont } \\
\text { periostitis, spondylitis } \\
\text { tuberculosa (Pott } \\
\text { gibbus) } \\
\end{array}$ & femur & + & - \\
\hline 4028 & $20-25$ & férfi & $\begin{array}{c}\text { bilateralis cribra } \\
\text { orbitalia, endocranialis }\end{array}$ & fog & - & n.d. \\
\hline
\end{tabular}




\begin{tabular}{|c|c|c|c|c|c|c|}
\hline & & $\begin{array}{c}\text { elváltozás, hosszúcsont } \\
\text { periostitis }\end{array}$ & femur & - & n.d. \\
\hline
\end{tabular}

2. táblázat: Az Alsónyék-Kanizsa dűlő lelőhely 13. sírcsoport 38 humán maradványa csontmintáit, azok morfológiai és molekuláris biológiai eredményeit összefoglaló táblázata (Pósa et al, 2016a).

A 4027-es sírból származó 30-40 év közötti férfi különös jelentőséggel bír: a gerincen megfigyelhető jellegzetes krónikus spondylitis tuberculosa (Pott-féle púp) mellett a koponyán endocranialis elváltozások és cribra orbitalia, míg a bordákon és a hosszúcsontokon periostitis jeleit észleltük. Ebben az esetben mind a hosszúcsontokból, mind a fogakból vett minták esetén pozitív eredményt kaptunk az IS6110 repetitív elem tekintetében, ezzel egyértelmüen alátámasztva a Mycobacterium tuberculosis aDNS jelenlétét az egyén maradványaiban (Pósa et al, 2015b; 2016a). Ez az eset összecseng Comas és munkatársai felvetésével, miszerint a neolitikum nem elsősorban azzal járult hozzá a tbc terjedésének sikeréhez, hogy megjelent az állattartás, hanem azzal, hogy ezzel növekedett a fertőzhető gazdaszervezetek sürüsége (Comas et al, 2013). Ez az eset összhangban van több más, a neolitikum hasonló szakaszába eső, konfirmált hazai tbc előfordulással (Masson et al, 2013, 2015), valamint a tízezer évnél régebbi szíria esetekkel (Baker et al, 2015) és határozottan ellentmond Bos és munkatársai számításokon alapuló tbc-evolúciós modelljének (Bos et al, 2014). 


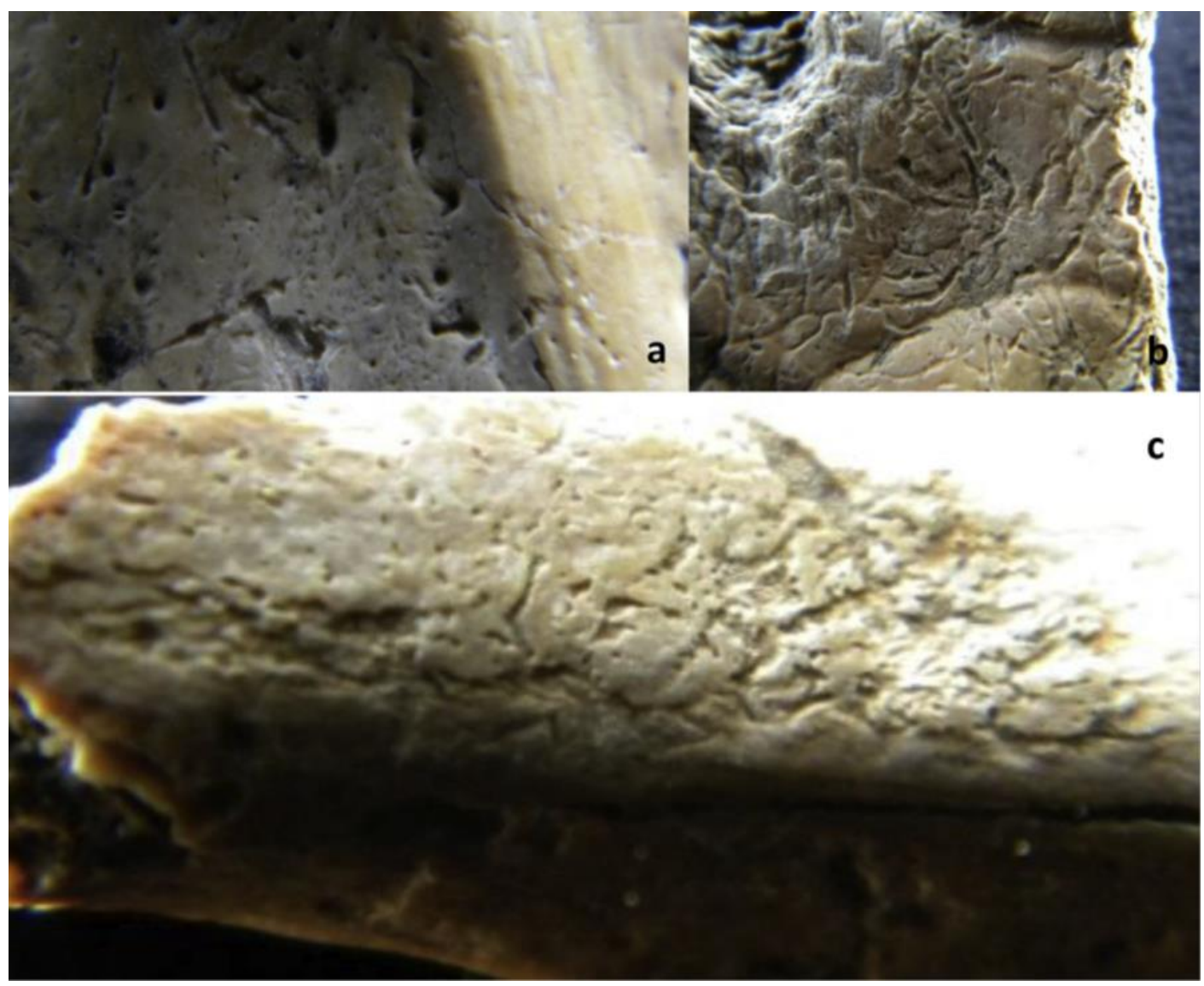

15. ábra a-b-c: Egy 6-7 év körüli gyermek csontmaradványai (256-os sír); 15. ábra a-b: endocranialis elváltozások 15. ábra c: borda periostitis (Pósa et al, 2015b).

A másik neolit kori temető molekuláris vizsgálataiba öt egyén maradványait vontam be a Vésztő Mágori-domb neolit lelöhelyéröl, ahol négy esetben a morfológiai vizsgálatok tbc-re utaló elváltozásokat jegyeztek fel. Egy egyén elváltozásmentes volt, mely kontrollként szolgált a vizsgálat során. Egyénenként három mintavételi helyet borda, hosszúcsont és fog - alkalmaztunk, ahol azt a maradványok megtartása engedélyezte. A 6. sír és a 33. sír esetében ez nem volt lehetséges: előbbinél nem állt rendelkezésre fogminta, míg utóbbinál csupán néhány fog, ill. koponya maradványok voltak a sírban.

A vizsgálat alapját képező morfológiai vizsgálatok eredményeit az alábbi összefoglaló táblázat tartalmazza (3. táblázat). 


\begin{tabular}{|c|c|c|c|c|c|}
\hline Sírszám & $\begin{array}{c}\text { Elhalálozási } \\
\text { életkor }\end{array}$ & Sexus & Mintavételi helyek & Léziók & PCR \\
\hline 5. & Infantia II & & $\begin{array}{l}\text { temporalis csont, } \\
\text { fog }\end{array}$ & $\begin{array}{c}\text { endocranialis } \\
\text { elváltozás, cribra } \\
\text { orbitalia, cribra } \\
\text { cranii }\end{array}$ & - \\
\hline 6. & Maturus & nö & $\begin{array}{c}\text { borda, bal humerus, } \\
\text { fog }\end{array}$ & $\begin{array}{c}\text { diffúz, szimmetrikus } \\
\text { periostitis a } \\
\text { femurokon, tibiákon, } \\
\text { fibulákon és a } \\
\text { radiusok disztális } \\
\text { részén } \\
\end{array}$ & - \\
\hline 13. & Adultus & férfi & $\begin{array}{l}\text { borda, jobb } \\
\text { humerus, fog }\end{array}$ & $\begin{array}{c}\text { csigolya } \\
\text { hypervascularisatio, } \\
\text { mindkét tibián } \\
\text { periostitis } \\
\end{array}$ & + \\
\hline 33. & Juvenis & férfi & $\begin{array}{l}\text { borda, jobb } \\
\text { humerus }\end{array}$ & $\begin{array}{c}\text { csigolya } \\
\text { hypervascularisatio, } \\
\text { femurokon és tibiákon } \\
\text { periostitis, cribra } \\
\text { orbitalia } \\
\end{array}$ & - \\
\hline 39. & & & borda, tibia, fog & - & - \\
\hline
\end{tabular}

3. táblázat: A Vésztő Mágori-dombon fellelt - antropológiai vizsgálatok alapján feltehetőleg tuberkulózissal fertőzött - egyének felsorolása, a korcsoportok, a morfológiai léziók és a molekuláris eredmények feltüntetésével.

Az 5. sírban talált 10-12 éves gyermek maradványai rendkívül töredékes állapotban álltak az antropológusok rendelkezésére, azonban a vizsgált koponyacsontokon endocranilis elváltozás jeleit, ill. cribra orbitalia-t és cribra cranii-t fedeztek fel.

A 6. sírból származó 50-60 év körüli nő esetében diffúz szimmetrikus periostitist jegyeztek fel a femurokon, a tibiákon, a fibulákon, valamint a radiusok disztális részén.

A 13. sír, amely egy 30-40 év körüli férfi maradványait tartalmazta, ahol csigolya hypervascularisatio és mindkét tibián megfigyelhető periostitis nyomait (16. ábra) azonosították a morfológiai vizsgálatok során (Spekker et al, 2012). Ebben az esetben molekuláris vizsgálatokkal kimutathatók voltak Mycobacterium tuberculosis aDNS maradványai (Pósa et al, 2013).

A 33. sírból származó 16-18 év körüli juvenis korú férfi maradványai csigolya hypervascularisatio-t és periostitis-t mutattak a femurokon és tibiákon, továbbá cribra orbitalia jelei voltak felismerhetők. 
A 39. sírból származó egyén nem mutatott tbc-re utaló elváltozást sem a koponyán, sem a postcranialis vázon, az egyén kontrollként szolgált a vizsgálatok során.

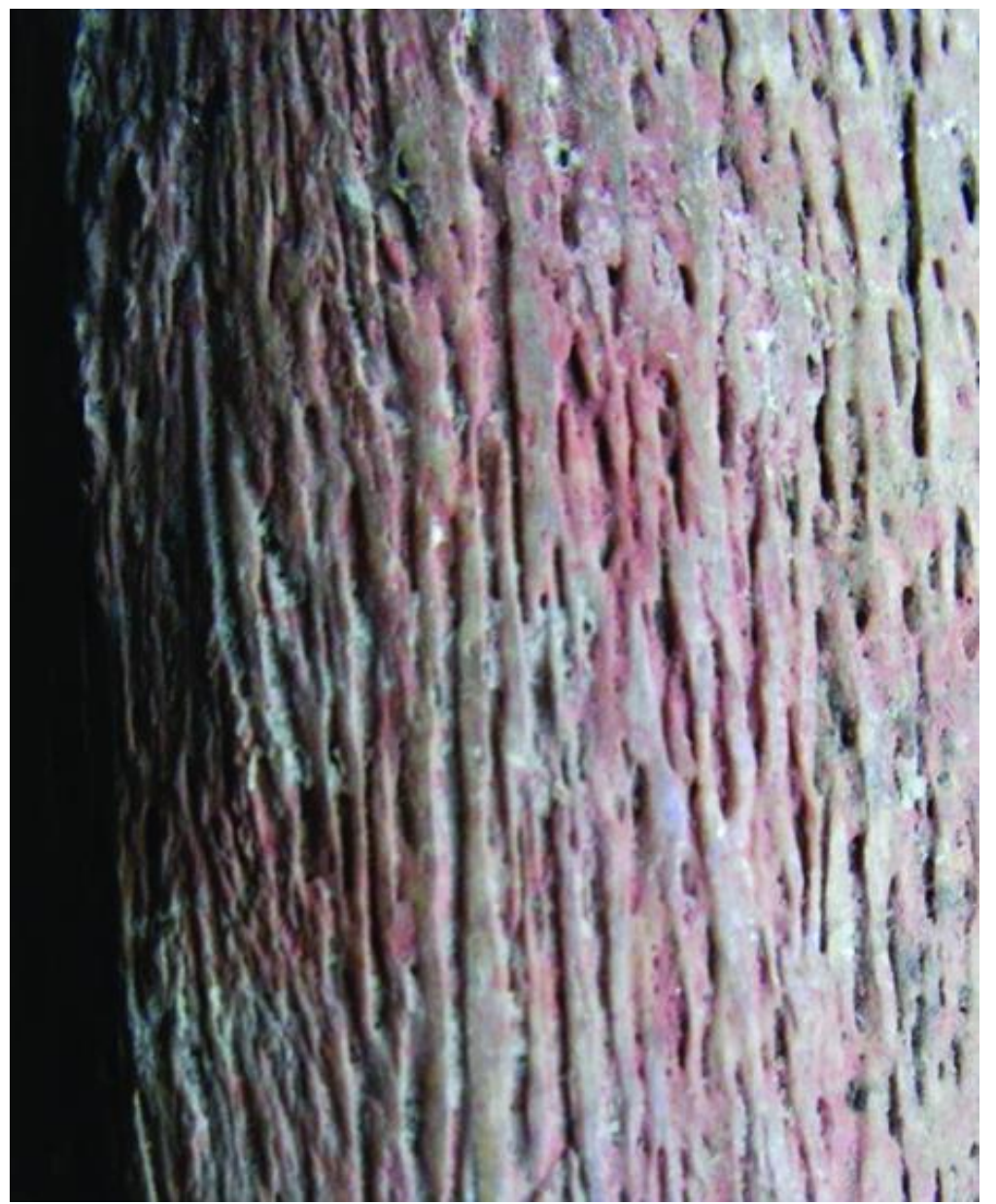

16. ábra: A Vésztő Mágori-dombon feltárt neolit temető 13. sírjából származó 30-40 év körüli férfi tibia periostitis-e. (Spekker et al, 2012; Pósa et al, 2012a) 


\subsection{Bronzkor}

A EURAC bolzanoi kutatólaboratóriumában (Institute For Mummies And The Iceman) végeztem paleomikrobiológiai vizsgálatokat a 3.2. fejezetben ismertetett, TápéSzéntéglaégető lelőhely egy késő bronzkori temetőjének hét egyénből származó mintáin, amely egyének tbc-vel összefüggésbehozható morfológiát mutattak.

Az 51-es sírból származó Juvenis korú egyén esetén, thoracalis csigolya hypervascularisatio, hosszúcsont periostitis a jobb os coxae-n, mindkét tibián, valamint mindkét fibulán.

A 61-es Infantia I-es korú csontvázon enocranialis léziók voltak megfigyelhetőek.

A 103-as sírban Infantia II-es korú csontmaradványokon thoracalis és lumbalis csigolya hypervascularisatio, endocranialis léziók, hosszúcsont periostitis, mindkétoldali femuron és tibián.

A 331-es Infantia II-es korú egyén esetében endocranialis léziók, valamint hosszúcsont periostitis nyomai voltak fellelhetők mindkétoldali femuron és tibián, továbbá a fibulákon.

Az 514-es maradványokon, melyek elhalálozási kora Juvenis (férfi), thoracalis és lumbalis csigolya hypervascularisatio, hosszúcsont periostitis a jobb femuron, bal tibián, ill. a jobb és bal oldali fibulán volt megfigyelhető.

Az 529-es Infantia II esetében szintén thoracalis és lumbalis csigolya hypervascularisatio és endocranialis léziók voltak.

Míg a 608-as Juvenis korú férfi maradványain thoracalis és lumbalis csigolya hypervascularisatio és endocranialis léziókat figyeltek meg az antropológusok (4. táblázat). 


\begin{tabular}{|c|c|c|c|c|c|}
\hline Sírszám & Elhalálozási életkor & Sexus & $\begin{array}{c}\text { Mintavételi } \\
\text { hely }\end{array}$ & Léziók & PCR \\
\hline 51. & Juvenis & & $\begin{array}{l}\text { jobb femur, } \\
\text { fog: } 44,46\end{array}$ & $\begin{array}{c}\text { csigolya } \\
\text { hypervascularisatio, } \\
\text { hosszúcsont } \\
\text { periostitis: jobb os } \\
\text { coxae, jobb és bal } \\
\text { tibia, jobb és bal } \\
\text { fibula }\end{array}$ & - \\
\hline 61. & Infantia I & & $\begin{array}{l}\text { bal femur, } \\
\text { fog: } 85\end{array}$ & endocranialis léziók & - \\
\hline 103. & Infantia II & & $\begin{array}{l}\text { jobb femur, } \\
\text { fog: } 36,44\end{array}$ & $\begin{array}{c}\text { csigolya } \\
\text { hypervascularisatio, } \\
\text { endocranialis léziók, } \\
\text { hosszúcsont } \\
\text { periostitis: jobb és bal } \\
\text { femur, jobb és bal } \\
\text { tibia }\end{array}$ & - \\
\hline 331. & Infantia II & & jobb femur & $\begin{array}{c}\text { endocranialis léziók, } \\
\text { hosszúcsont } \\
\text { periostitis: jobb és bal } \\
\text { femur, jobb és bal } \\
\text { tibia, jobb és bal } \\
\text { fibula }\end{array}$ & - \\
\hline 514. & Juvenis & férfi & $\begin{array}{l}\text { jobb femur, } \\
\text { fog: } 18,44\end{array}$ & $\begin{array}{l}\text { csigolya } \\
\text { hypervascularisatio, } \\
\text { hosszúcsont } \\
\text { periostitis: jobb } \\
\text { femur, bal tibia, jobb } \\
\text { és bal fibula }\end{array}$ & - \\
\hline 529. & Infantia II & & $\begin{array}{c}\text { jobb femur, } \\
\text { fog: } 74\end{array}$ & $\begin{array}{c}\text { csigolya } \\
\text { hypervascularisatio, } \\
\text { endocranialis léziók }\end{array}$ & - \\
\hline 608. & Juvenis & férfi & $\begin{array}{l}\text { bal femur, } \\
\text { fog: } 24,27\end{array}$ & $\begin{array}{c}\text { csigolya } \\
\text { hypervascularisatio, } \\
\text { endocranialis léziók }\end{array}$ & - \\
\hline
\end{tabular}

4. táblázat: A Tápé-Széntéglaégetőn fellelt - antropológiai vizsgálatok alapján feltehetőleg tuberkulózissal fertőzött - egyének felsorolása, a korcsoportok és a morfológiai léziók feltüntetésével (Spekker és Molnár adatai alapján). A jobb szélső oszlop a molekuláris vizsgálati eredményeket tartalmazza.

A megfigyelt morfológiai elváltozások ellenére a kórokozó DNS-t egyik esetben sem sikerült azonosítani, feltételezhetően ez annak köszönhetö, hogy a csontok makroszkópos megtartási állapota eleve nagyon gyenge volt, ami hatással lehetett azok 
DNS-megtartó képességére. Mivel a feltárásokra a '60-as években került sor, így az esetleg megmaradt aDNS időközben tovább degradálódhatott a tárolási körülmények következtében. 


\subsection{Avar kor}

A fentebb leírt bronzkori temetőhöz hasonlóan, a paleomikrobiológiai vizsgálatokra a EURAC bolzanoi kutatólaboratóriumában (Institute For Mummies And The Iceman) került sor. A Szeged-Kiskundorozsma Kettőshatár II. lelöhely 263-as sírjában talált csontmaradványokon atípusos tbc-re utaló elváltozásokat találtak az SZTE Embertani Tanszék munkatársai az antropológiai és paleopatológiai vizsgálatok során. A másik avar kori lelőhely, Hanzélytanya 12-es számú sírjában talált egyén esetén szintén atípusos tbc-vel összefüggésbe hozható tünetek kerültek feljegyzésre.

Egyik avar kori temető esetében sem sikerült DNS szinten igazolni a Mycobacterium jelenlétét, ami feltételezhetően annak köszönhető, hogy a csontok megtartási állapota rossz, így a DNS nem volt képes megőrződni detektálható mennyiségben. A minták rossz prezervációs képessége abból is fakadhat, hogy a régészeti ásatásokat követően hosszú időn át a csontokat csak szélsőséges hőmérsékletkülönbözetet lehetővé tevő körülmények között volt lehetőség tárolni, ami mind a bronzkori, mind az avar kori minták esetében is elmondható. A hőmérsékletingadozás kedvezőtlenül hat a csontokban található DNS megtartóképességére, így az degradálódhatott. Az optimális körülmények az aDNS vizsgálatokra szánt csontminták esetében, ha hosszútávon, állandó $-4^{\circ} \mathrm{C}$ hőmérsékleten tároljuk ${ }^{* * *}$.

*** Az irodalomban nincs egységes megegyezés a csontok tárolására a későbbiekben DNSvizsgálatokra szánt minták esetében. Az azonban erősen valószínüsíthető, hogy az SZTE Embertani Tanszék gyüjteményének éves szinten megközelítően -10 és +30 fok közötti, negyven celzius fokot is elérő hőingadozása károsan befolyásolja a csontok aDNS megtartó képességét. 


\section{4 Árpád-kor}

Az elsődleges molekuláris vizsgálatokba egy egyén humerus-át és femur-ját vontuk be, annak igazolására, hogy megerősítsük a Mycobacteriális-fertőzés jelenlétét ebben az Árpád-kori temetőben.

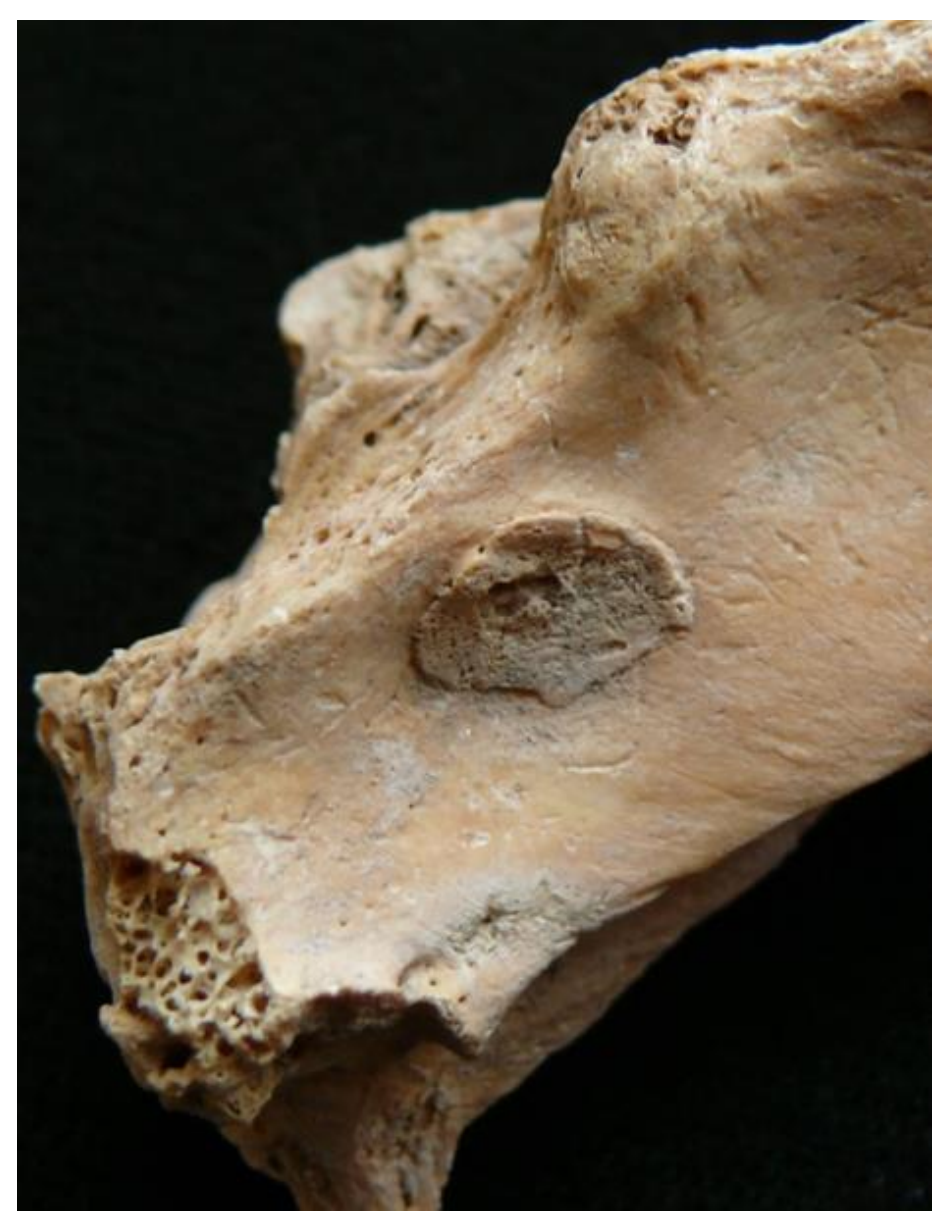

17. ábra: Periostitis nyomai láthatóak a collum costae közelében, a borda zsigeri felszínén (Adultus-Maturus korú férfi csontváza (Győr-Pósdomb, 187-es sír) (Pósa et al, 2014).

A Győr-Pósdomb 187-es sírszámú 36-42 éves (adult.-mat.) férfi koponyája nem mutatott tbc-re utaló kóros elváltozást. Azonban a postcranialis csontokon több morfológiai lézió volt megfigyelhető; (periostitis) nyomai a bordákon (17. ábra), a femuron, tibia-n, a kulcscsontok sternalis végein. 


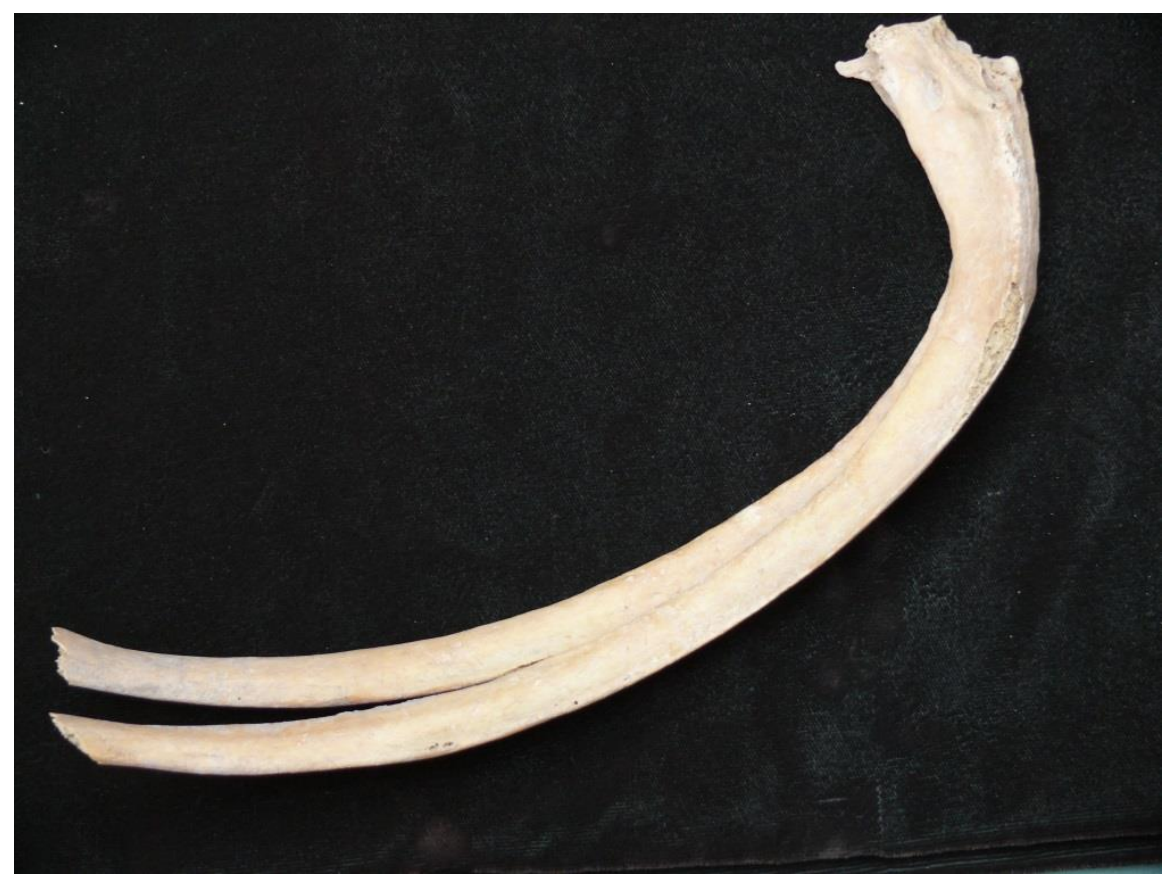

18. ábra: A jobb oldali hatos-hetes bordák összecsontosodása (Győr-Pósdomb, 187-es sír) (Pósa et al, 2014).

A jobb oldali bordák (hatos, hetes) a gerinc felöli végükön összecsontosodtak (18. ábra). Mindkét facies auricularis esetében megfigyelhető gyulladásos elváltozás. A vizsgálatok elsődleges aktualitását adó, a gerincoszlopon megfigyelhető jellegzetes Pott-gibbus csigolya tbc-re utal, ahol a thoracalis 4-9-es csigolyák összeroppanása, ill. összecsontosodása figyelhető meg (19. ábra). A spondylitis tuberculosa jelenségével összhangban állhat a vélhetően fertőzéses eredetű kétoldali sacroileitis. 


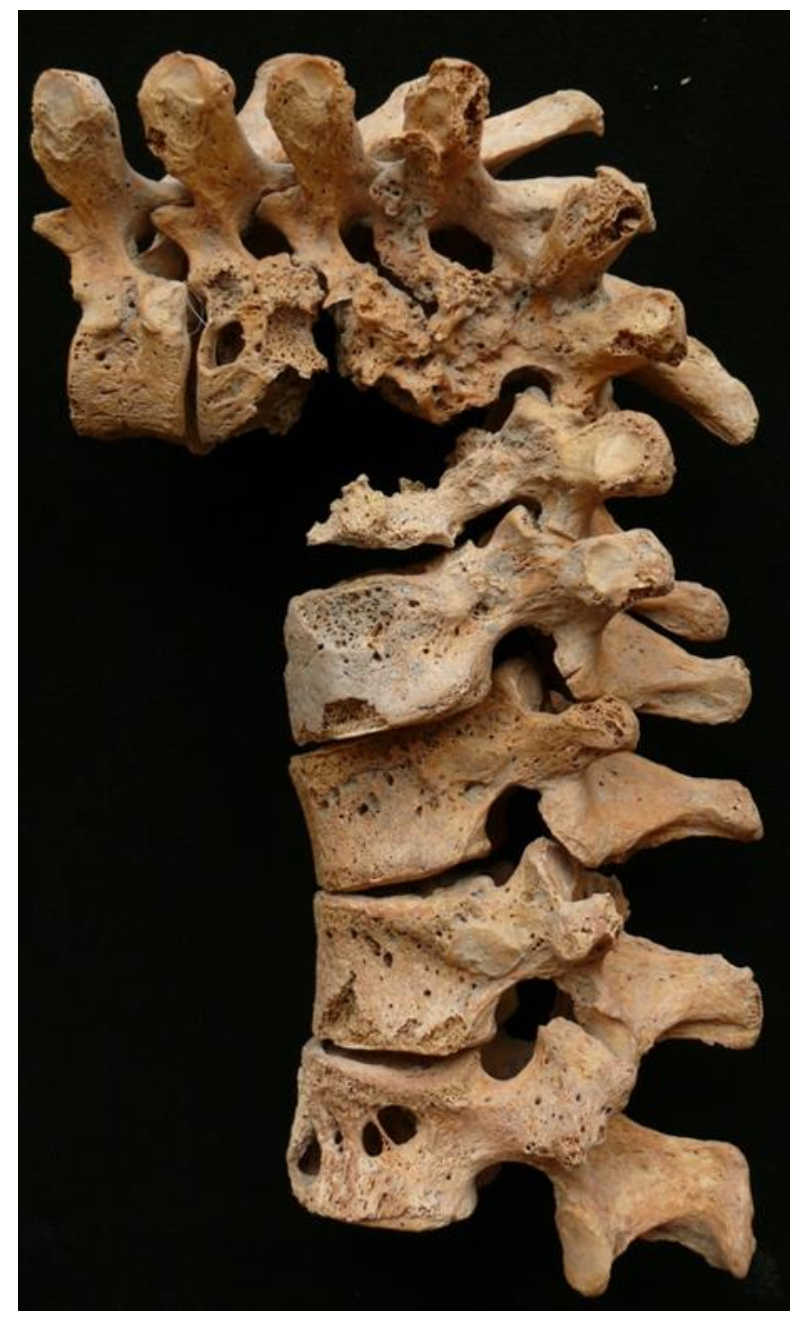

19. ábra: A Győr-Pósdomb lelőhelyről (187. sír Adultus-Maturus, férfi) előkerült Pott-gibbus-os eset (Pósa et al, 2014).

A molekuláris vizsgálatok alapján mind a humerus-ból, mind a femur-ból vett minták esetén pozitív eredményt kaptunk MTB aDNS vizsgálatára, mellyel bizonyítottuk az egyén tbc-fertőzöttségét (Pósa et al, 2016b). 


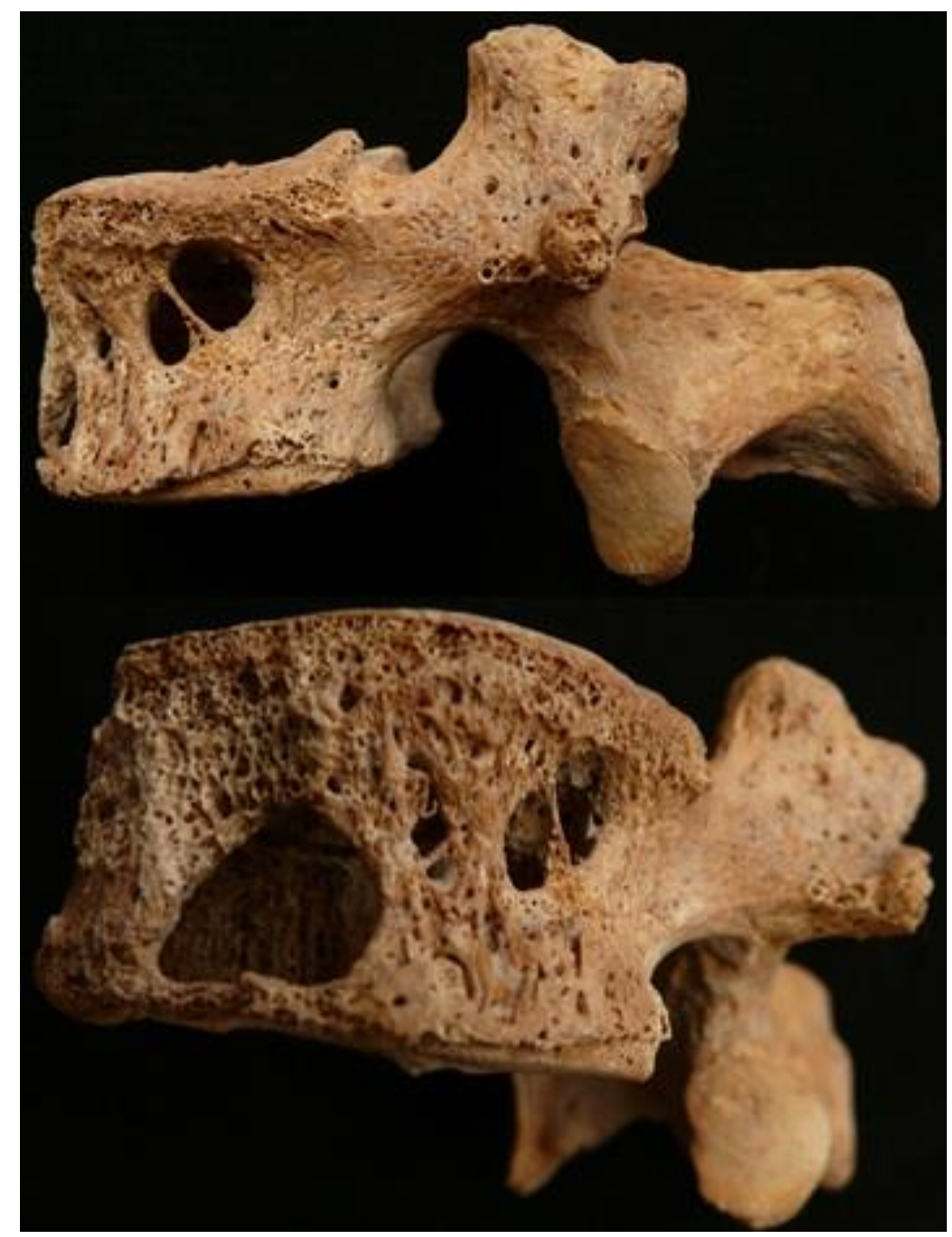

20. ábra: Spondylitis tuberculosa - tbc-fertőzés okozta csigolyatest-pusztulás (Győr-Pósdomb lelőhely, 187. sír, Adultus-Maturus, férfi) (Pósa et al, 2014).

A tipizáló vizsgálatok, amelyek választ adhatnak azon kérdéseinkre, hogy a Mycobacterium tuberculosis komplexnek melyik tagja okozott megbetegedést a pósdombi népességben, jelenleg is folyamatban vannak. 


\subsection{Középkor}

A bácsalmás-óalmási temető több éves, makromorfológiai alapú paleopatológiai elemzése során a vizsgált 481 csontvázból 283 lehetséges tbc-fertőzött esetet jegyeztek fel az antropológusok (105 felnőtt és 178 gyermek) (Lovász, 2015). A lehetséges tbc-re utaló léziók több mint fele - 62,9\% - gyermek csontvázakon került regisztrálásra. Ki kell emelnünk, hogy a morfológiai vizsgálatok során kiemelten nagyszámú korai stádiumú tbc elváltozást írtak le. A korai stádiumú esetekben spondylodiscitist és arthritist észleltek 24 esetben, borda elváltozásást 190 esetben, csigolya hypervascularisacio-t 101 esetben és endocranialis elváltozást 73 esetben. A tbc-re utaló egyéb léziókat, ill. fertőzéshez kapcsolódó ún. stressz faktorokat is azonosítottak: 222 esetben periostealis átépülést, 65 cribra orbitalia-t és 9 cribra cranii-t. A megfigyelt léziók nagy száma azt is jelzi, hogy azok általában halmozottan (asszociáltan) jelentkeztek.

A EURAC bolzanoi kutatólaboratóriumában (Institute For Mummies And The Iceman) két tanulmányút során nyílt lehetőségem, Albert Zink professzor és Dr. Frank Maixner útmutatása nyomán a 3.5.1 fejezetben ismertetett, 18 egyénböl szelektált 56 minta paleomikrobiológiai vizsgálatára. Molekuláris eredményeink alapján a 18 kiválasztott egyénből 7 bizonyult tbc-pozitívnak (38,9\%) a M. tuberculosis IS6110 régiójának jelenlétére (5. táblázat és 21 . ábra). 


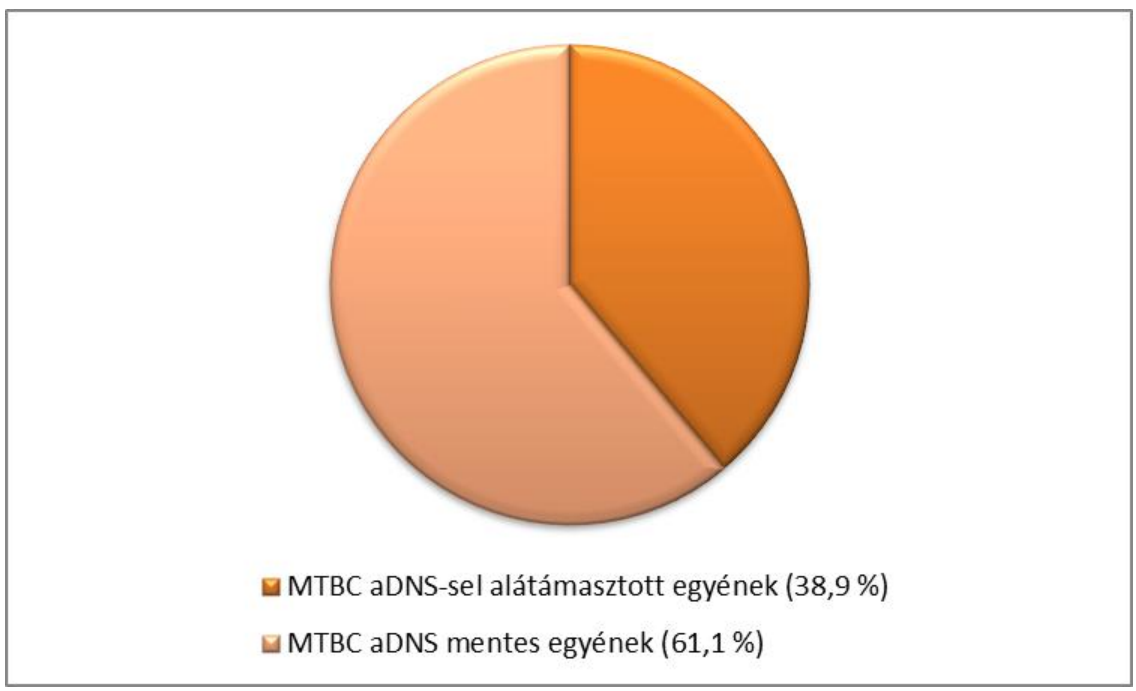

21. ábra: A molekuláris vizsgálatokba bevont embertani leletek megoszlása Mycobacteriális aDNS detektálhatósága szerint.

A hét molekulárisan pozitív esetből eredetileg négy mutatott valamilyen tbc-re utaló morfológiai elváltozást. 


\begin{tabular}{|c|c|c|c|c|c|}
\hline Sírszám & Elhalálozási életkor & Sexus & Mintavételi hely & Léziók & PCR \\
\hline 18 & Adultus & férfi & $\begin{array}{l}\text { jobb borda, jobb } \\
\text { radius, T11 } \\
\text { csigolya }\end{array}$ & $\begin{array}{c}\text { valószínü } \\
\text { spondylitis } \\
\text { tuberculosa, } \\
\text { felszíni } \\
\text { csigolyaléziók, } \\
\text { valószínú } \\
\text { sacroileitis, } \\
\text { periostitis } \\
\text { hosszúcsontokon }\end{array}$ & + \\
\hline 105 & Maturus & nő & $\begin{array}{l}\text { bal borda, bal } \\
\text { radius, L1 csigolya }\end{array}$ & $\begin{array}{l}\text { periostitis bal } \\
\text { oldali bordák } \\
\text { visceralis } \\
\text { felszínén, } \\
\text { periostitis } \\
\text { hosszúcsontokon }\end{array}$ & + \\
\hline 175 & Adultus & nő & $\begin{array}{l}\text { koponyacsont, } \\
\text { csigolya, radius, } \\
\text { borda, fog }\end{array}$ & $\begin{array}{c}\text { periostitis } \\
\text { hosszúcsontokon, } \\
\text { endocranialis } \\
\text { lézió, periostitis } \\
\text { bordákon }\end{array}$ & - \\
\hline 208 & Senium & férfi & $\begin{array}{l}\text { radius, csigolya, } \\
\text { borda, fog }\end{array}$ & $\begin{array}{c}\text { valószínü } \\
\text { spondylitis } \\
\text { tuberculosa, } \\
\text { periostitis } \\
\text { hosszúcsontokon, } \\
\text { periostitis } \\
\text { bordákon, } \\
\text { sacroileitis } \\
\end{array}$ & - \\
\hline 261 & Infantia I & & $\begin{array}{l}3 \text { borda, bal tibia, } \\
\text { csigolya fragment }\end{array}$ & $\begin{array}{l}\text { periostitis } \\
\text { bordákon, } \\
\text { periostitis } \\
\text { bordákon, }\end{array}$ & - \\
\hline 264 & Infantia I & & $\begin{array}{c}3 \text { borda, bal } \\
\text { humerus, } \\
\text { csigolyafragment, } \\
\text { bal koponyacsont, }\end{array}$ & $\begin{array}{l}\text { periostitis bordák } \\
\text { visceralis } \\
\text { felszínén, } \\
\text { endocranialis } \\
\text { léziók (valószínű } \\
\text { tbc-s } \\
\text { meningitis), } \\
\text { periostitis } \\
\text { hosszúcsontokon }\end{array}$ & + \\
\hline 326 & Adultus & férfi & $\begin{array}{l}\text { radius, csigolya, } \\
\text { borda, fog }\end{array}$ & - & + \\
\hline 332 & Maturus & férfi & $\begin{array}{l}\text { jobb borda, jobb } \\
\text { radius, T11 } \\
\text { csigolya }\end{array}$ & - & - \\
\hline 344 & Juvenis & & $\begin{array}{l}\text { bal borda, jobb } \\
\text { radius, T11 } \\
\text { csigolya }\end{array}$ & $\begin{array}{l}\text { valószínü arthritis } \\
\text { tuberculosa (bal } \\
\text { könyök), felszíni } \\
\text { csigolyaléziók, } \\
\text { endocranialis }\end{array}$ & - \\
\hline
\end{tabular}




\begin{tabular}{|c|c|c|c|c|c|}
\hline & & & & $\begin{array}{c}\text { léziók, cribra } \\
\text { orbitalia }\end{array}$ & \\
\hline Sírszám & Elhalálozási életkor & Sexus & Mintavételi hely & Léziók & PCR \\
\hline 391 & Juvenis & & $\begin{array}{l}\text { bal borda, bal } \\
\text { radius, } \mathrm{T} 12 \\
\text { csigolya }\end{array}$ & $\begin{array}{c}\text { arthritis } \\
\text { tuberculosa (jobb } \\
\text { könyök), felszíni } \\
\text { csigolyaléziók, } \\
\text { periostitis } \\
\text { hosszúcsontokon }\end{array}$ & + \\
\hline 409 & Juvenis & & $\begin{array}{l}\text { radius, csigolya, } \\
\text { borda, fog }\end{array}$ & $\begin{array}{c}\text { felszíni } \\
\text { csigolyaléziók, } \\
\text { endocranialis } \\
\text { léziók, periostitis } \\
\text { hosszúcsontokon }\end{array}$ & - \\
\hline 410 & Infantia II & & $\begin{array}{l}\text { radius, csigolya, } \\
\text { borda, fog }\end{array}$ & $\begin{array}{c}\text { periostitis } \\
\text { hosszúcsontokon }\end{array}$ & - \\
\hline 416 & Infantia II & & $\begin{array}{l}\text { bal borda, jobb } \\
\text { radius, T12 } \\
\text { csigolya }\end{array}$ & $\begin{array}{c}\text { felszíni } \\
\text { csigolyaléziók, } \\
\text { periostitis } \\
\text { hosszúcsontokon } \\
\end{array}$ & - \\
\hline 423 & Infantia I & & $\begin{array}{l}\text { koponyacsont, } \\
\text { tibia, csigolya, } \\
\text { borda, fog }\end{array}$ & $\begin{array}{c}\text { felszíni } \\
\text { csigolyaléziók, } \\
\text { endocranialis } \\
\text { léziók, cribra } \\
\text { orbitalia, } \\
\text { sacroileitis }\end{array}$ & - \\
\hline 438 & Infantia I & & $\begin{array}{l}2 \text { borda, bal } u \ln a, \\
\text { csigolyatest }\end{array}$ & - & + \\
\hline 447 & Maturus & férfi & $\begin{array}{l}\text { bal borda, jobb } \\
\text { radius, T11 } \\
\text { csigolya }\end{array}$ & $\begin{array}{c}\text { periostealis } \\
\text { átépülés nyomai } \\
\text { bordák } \\
\text { visceralis } \\
\text { felszínén, } \\
\text { periostitis } \\
\text { hosszúcsontokon, } \\
\text { kalcifikálódott } \\
\text { objektum, } \\
\text { sacroileitis }\end{array}$ & - \\
\hline 481 & Adultus & nő & $\begin{array}{l}\text { jobb borda, bal } \\
\text { radius, } \mathrm{T} 12 \\
\text { csigolya }\end{array}$ & 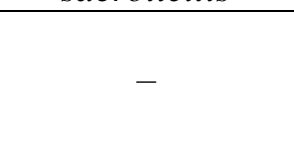 & + \\
\hline 483 & Infantia I & & $\begin{array}{l}2 \text { borda, bal } u \ln a, \\
\text { csigolyafragment, } \\
\text { jobb koponyacsont }\end{array}$ & $\begin{array}{c}\text { periostitis } \\
\text { bordákon, } \\
\text { endocranialis } \\
\text { léziók, periostitis } \\
\text { hosszúcsontokon, } \\
\text { cribra orbitalia }\end{array}$ & - \\
\hline
\end{tabular}

5. táblázat: A vizsgálatba bevont csontminták paleomikrobiológiai és morfológiai eredményei. 
A hét MTBC DNS-re pozitív esetet az alábbiakban részletesebben ismertetem.

A 18-as sírszámú, felnőtt (Adultus) férfi: lehetséges tbc-s spondylitis tuberculosa és superficialis csigolya elváltozások voltak megfigyelhetőek két alsó hátcsigolyán (22. ábra), továbbá periostealis elváltozások több hosszúcsont esetén. Ennél az egyénnél a tizenegyedik hátcsigolyából vett minta mutatott tbc baktériumra jellemző aDNS pozitivitást.

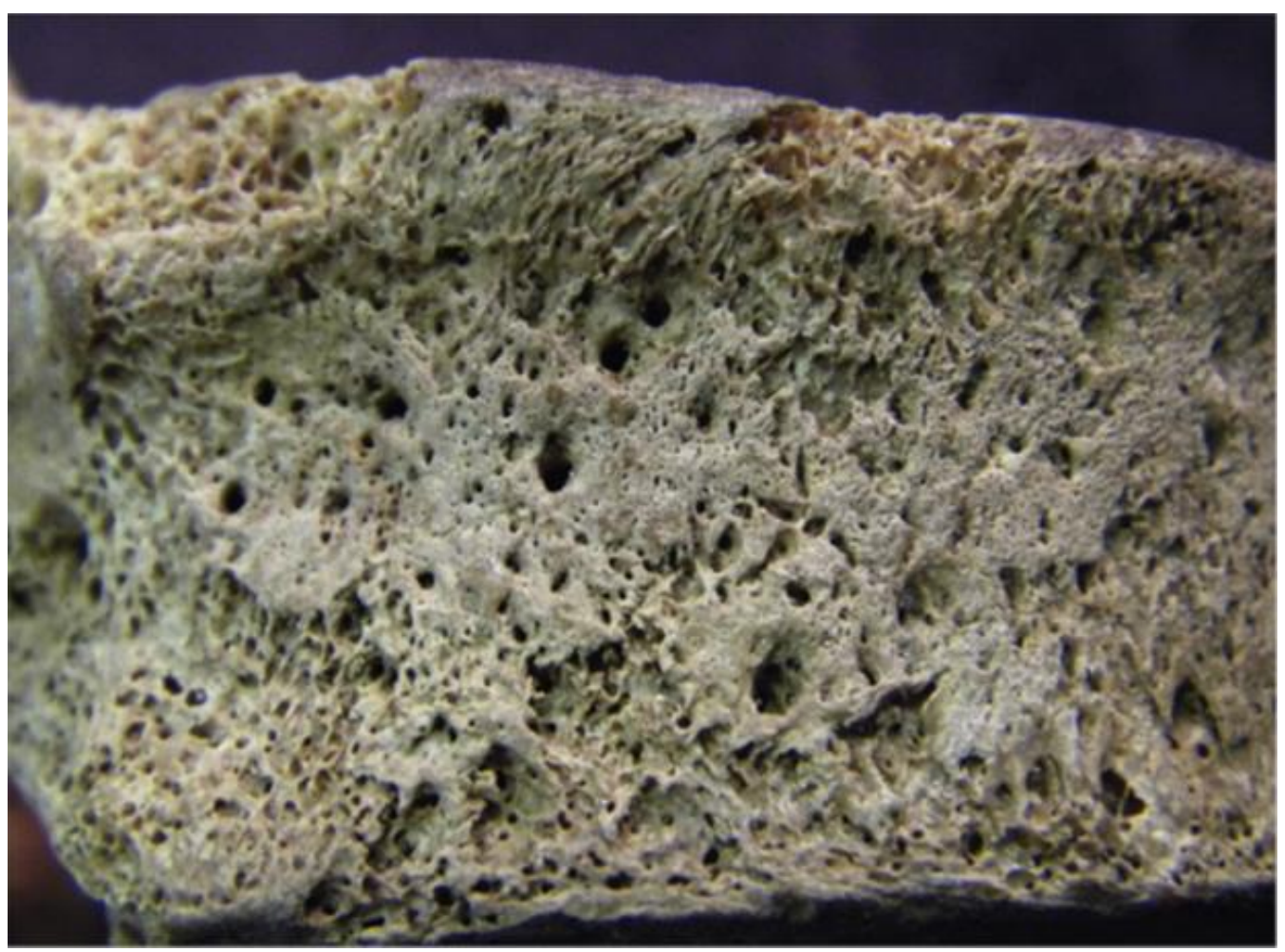

22. ábra: Felszíni újcsont-képződés csigolyán

(Bácsalmás-Óalmás, 18-as sír, idős férfi) (Pósa et al, 2015a).

A 105-ös sírszámú, felnőtt (Maturus) nő: a fertőzéssel kapcsolatba hozható csontelváltozásokat észleltünk a bal oldali bordákon (a jobb oldali bordák nem mutattak a betegségre utaló jeleket). Bal oldali borda-minta esetén kaptunk pozitív eredményt a molekuláris vizsgálatokkal.

A 264-es sírszámú, fiatal gyermek (Infantia I): borda periostitis, diffúz periostitis a postcranialis csontvázon, valamint kifejezett endocranialis elváltozások voltak megfigyelhetők, melyek összefüggésbe hozhatók a tbc fertőzéssel (23. ábra). 


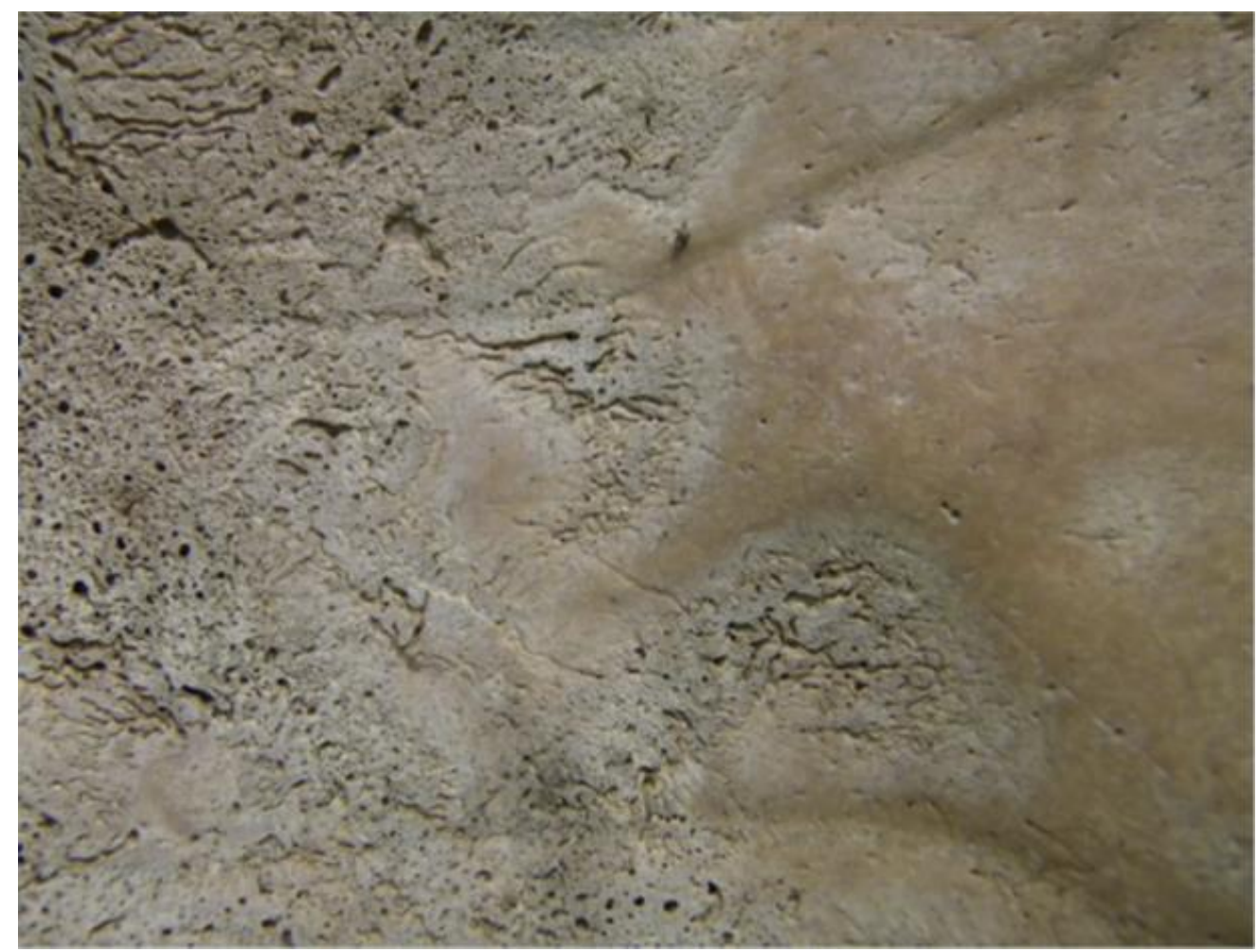

23. ábra: Meningitisre utaló súlyos endocranialis elváltozások a gyermek koponyáján (Bácsalmás-Óalmás, 264-es sír) (Pósa et al, 2015a).

A koponya endocraninialis felszínén megfigyelhető elváltozások súlyos meningitis-re utalnak. A pozitív DNS eredményt a M. tuberculosis komplex-re a bal humerus adta.

A 391-es sírszámú, Juvenis korú egyén: jobb könyökén súlyos arthritis jelei voltak megfigyelhetőek (24. ábra) továbbá néhány csigolyatesten újcsontképződés és hypervascularisatio, ill. a hosszúcsontokon periostitis nyomai. A kórokozóra pozitív DNS mintát a bal radius adta. 


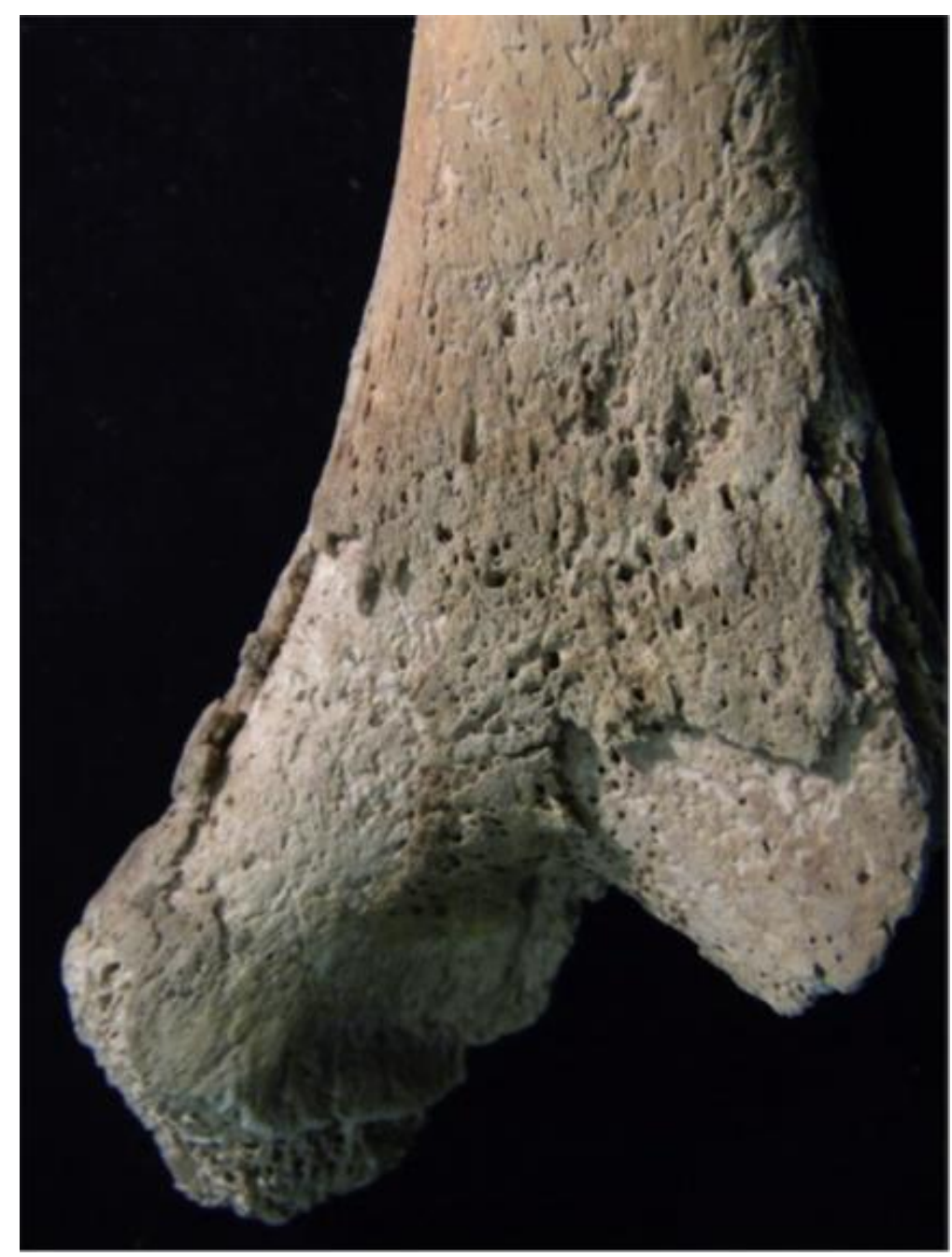

24. ábra: Osteitis, periostitis és feltételezhető ízületi destrukció nyomai egy ifjúkorú (Juv.) egyén jobb humerus distalis részén

(Bácsalmás-Óalmás, 391-es sír) (Pósa et al, 2015a).

A 438-as sírszámú, fiatal gyermek (Infantia I): annak ellenére, hogy semmilyen morfológiai elváltozás nem volt megfigyelhető a csontokon, az egyik minta pozitív DNS eredményt szolgáltatott: a vizsgált 3 mintából a bal oldali ulna-minta (ID 1212) adott pozitív PCR-eredményt (25. ábra; a 3 minta EURAC azonosítói: ID 1210-1212). 


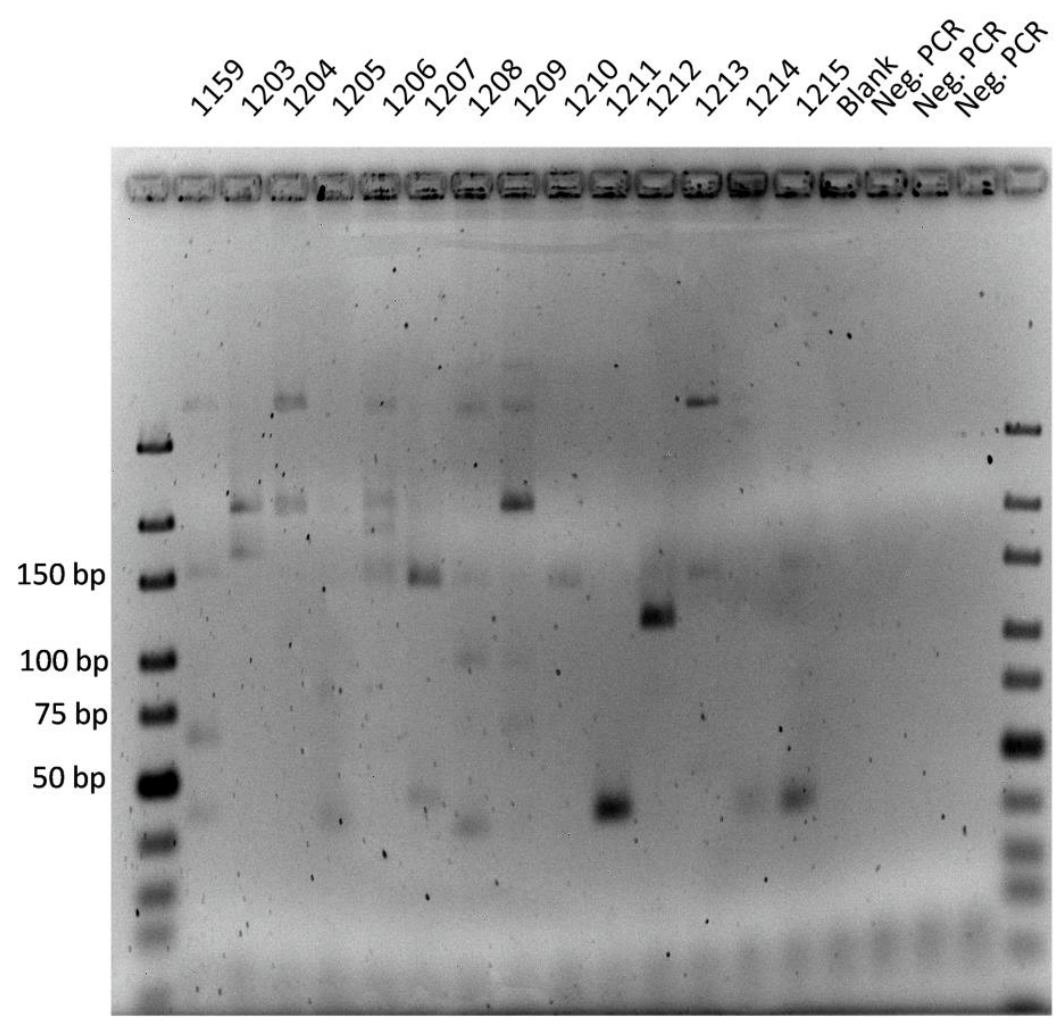

25. ábra: A Mycobacterium specifikus IS6110 szekvenciát (ID 1212) bemutató gél fényképe. (Inf. I, ID EURAC 1212). A baloldali ulna mintájából (ID 1212) sikerült a MTBC DNS azonosítása. (Bácsalmás-Óalmás, 438. sír) (Pósa et al, 2013).

A 481-es sírszámú, fiatal felnőtt (Adultus), nő: ebben az esetben sem volt semmilyen látható jele a fertőzésnek, de a csontmintákból sikeresen azonosítottuk a tbc aDNS-t. Ez volt az egyetlen olyan eset a szériából, ahol két minta is pozitív eredményt adott (bal radius és a tizenkettedik hátcsigolya).

A 326-os sírszámú, felnőtt (Adultus), férfi: nem mutatkozott semmilyen kóros elváltozásra utaló jel a csontvázon. Ez ckontrollmintaként szolgált a vizsgálatok során, mivel a morfológiai vizsgálatok alapján egészségesnek mondható, azonban a molekuláris vizsgálatok során MBTC DNS-t azonosítottunk a mintából. A kórokozó DNS a fogmintából lett azonosítva. Vélelmezhető, hogy az egyén korábban elhalálozott, minthogy a tbc csonttani tünetei kialakulhattak volna.

A fentiekben bemutatott hat egyén (18., 105., 264., 391., 438., 481. sír), hét pozitív (481. sír dupla pozitív) mintáját tovább vizsgáltuk spoligotyping módszerrel. Ez 
a vizsgálati módszer képes a spoligotyping mintázatuk alapján megkülönböztetni a Mycobacterium törzseket. Sajnos az aDNS nagymértékü degradációja miatt nem tudtuk egyértelmüen beazonosítani, hogy a Mycobacterium tuberculosis vagy a Mycobacterium bovis volt a fertőző törzs, mivel a spoligotyping mintázat rendkívül hiányos volt (26. ábra).

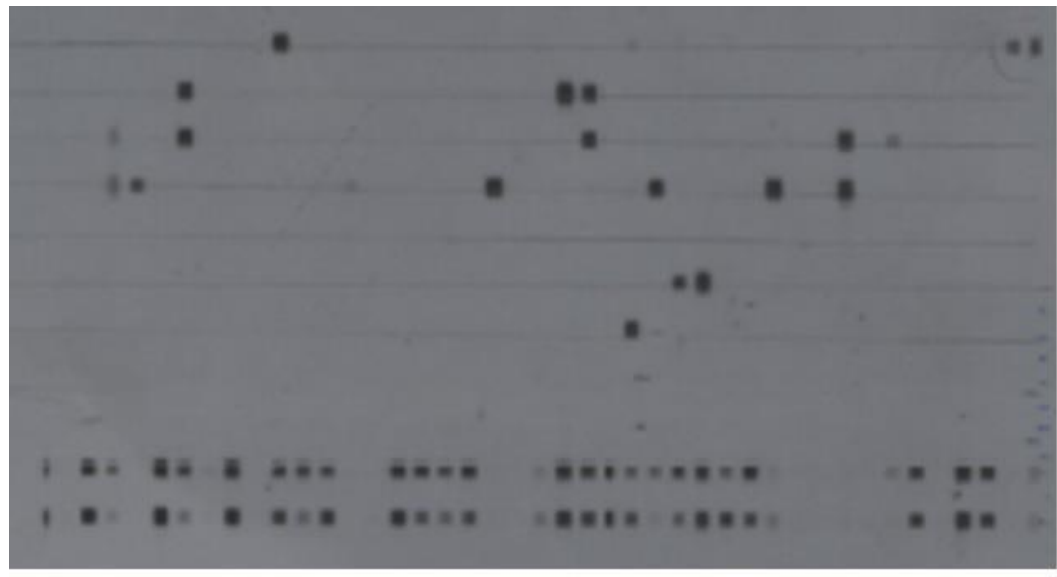

ID 1290 - Csongrád - Felgyó ID 1178 - Bácsalmás (481. sír) ID 1183 - Bácsalmás (391. sír) ID 1212 - Bácsalmás (438. sír) ID1180-Bácsalmás (481. sír) ID 1185 - Bácsalmás (105. sír) ID 1196 -Bácsalmás (18. sír) ID 1201 - Bácsalmás (264. sír)

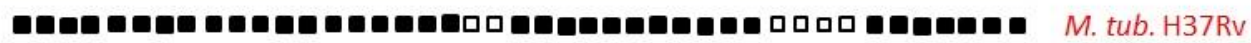

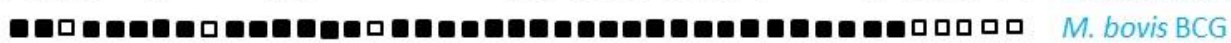

26. ábra: Spoligotyping membrán mintázata a Bácsalmás-Óalmás lelőhelyről származó hat egyén hét mintájáról, ill. egy korábban vizsgált tbc-vel fertőzött Csongrád-Felgyő, Ürmös-tanya lelőhelyről származó egyén esetén (Pósa et al, 2012a; Pálfi et al, 2015) (Képet készítette: Pósa Annamária).

A fertőzöttség arányából, ill. a nagyszámú „korai” morfológiai elváltozásból arra lehet következtetni, hogy magas fertőzőképességü Mycobacterium okozhatta a megbetegedéseket ebben a késő középkori endogám népességben. 


\section{6 Újkor}

Amint azt a vizsgálati anyagok ismertetésével foglalkozó fejezetben bemutattuk, lehetőségünk nyílt egy újkori váci múmia maradványainak tesztelésére is Sándor Terézia holttestének egy része tökéletesen mumifikálódott (27. ábra), azonban térdtől lefelé végbement a bomlás, így rendelkezésünkre álltak csontmaradványok is, anélkül, hogy a munifikálódott szöveti állományban roncsolást végeztünk volna a mintavétel során.A vizsgálatokhoz csont, kihullott fog és a testről levált mumifikálódott bőrdarabkát használtunk.

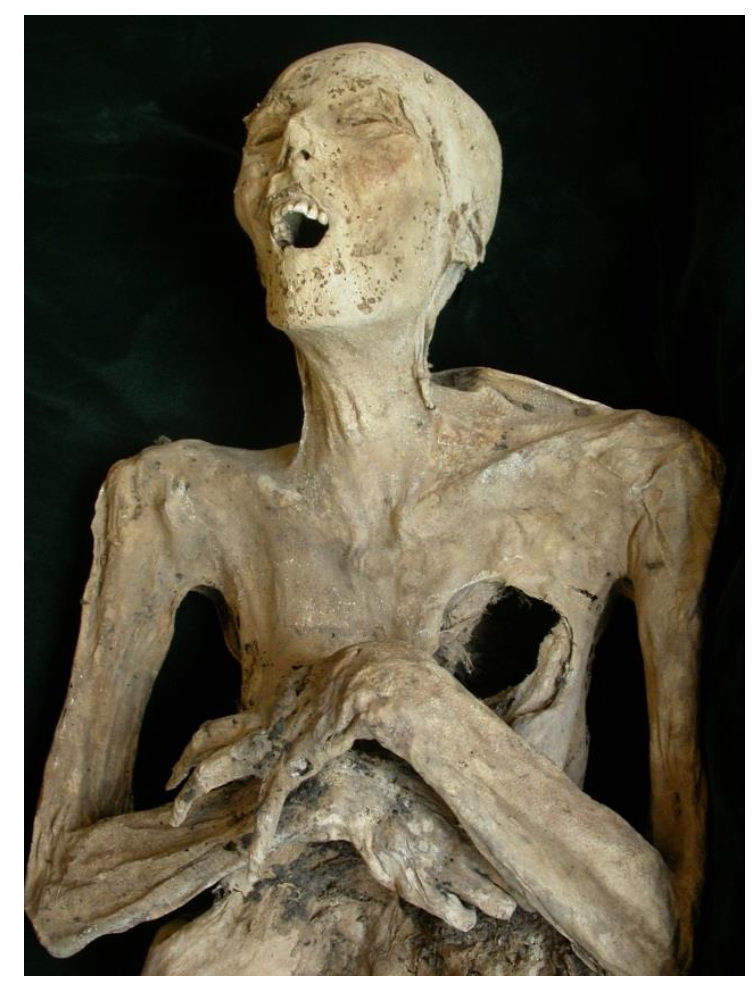

27. ábra: Sándor Terézia mumifikálódott maradványa a Magyar Természettudományi Múzeum Embertani Tár 18-19. századi váci múmiagyüjteményében (Szikossy et al, 2012, Pálfi György felvétele).

A tbc direkt paleopatológiai diagnosztikájához szükséges morfológiai vizsgálatokat nem állt módunkban elvégezni, mivel a mumifikálódás következtében a csontok nagy része morfológiai módszerekkel nem volt vizsgálható, mivel a csontokat a mumifikálódott lágyrészek fedték. A korábbi CT felvételek alapján azonban már 2003ban felismerhető voltak a múmiában a tüdő- és csigolya-tbc nyomai (Pálfi et al, 2003), 
míg az újabb kutatások és a 3D rekonstrukció egyértelmủen bizonyították a spondylitis tuberculosa rendkívül destruktív változatának kialakulását (Szikossy et al, 2012; Coqueugniot et al, 2015).

A molekuláris vizsgálatok során egy láb ujjperccsont (28. ábra) és a fog esetében Mycobacterium tuberculosis DNS-t nem sikerült detektáltunk, azonban a mumifikálódott bőrdarab esetében sikeresen igazoltuk baktérium DNS maradványainak jelenlétét. . A kriptában történt koporsós temetkezésnek köszönhetően ebben az esetben kizárható volt, hogy a kinyert DNS a talajból származó mycobacteriumokból származik.

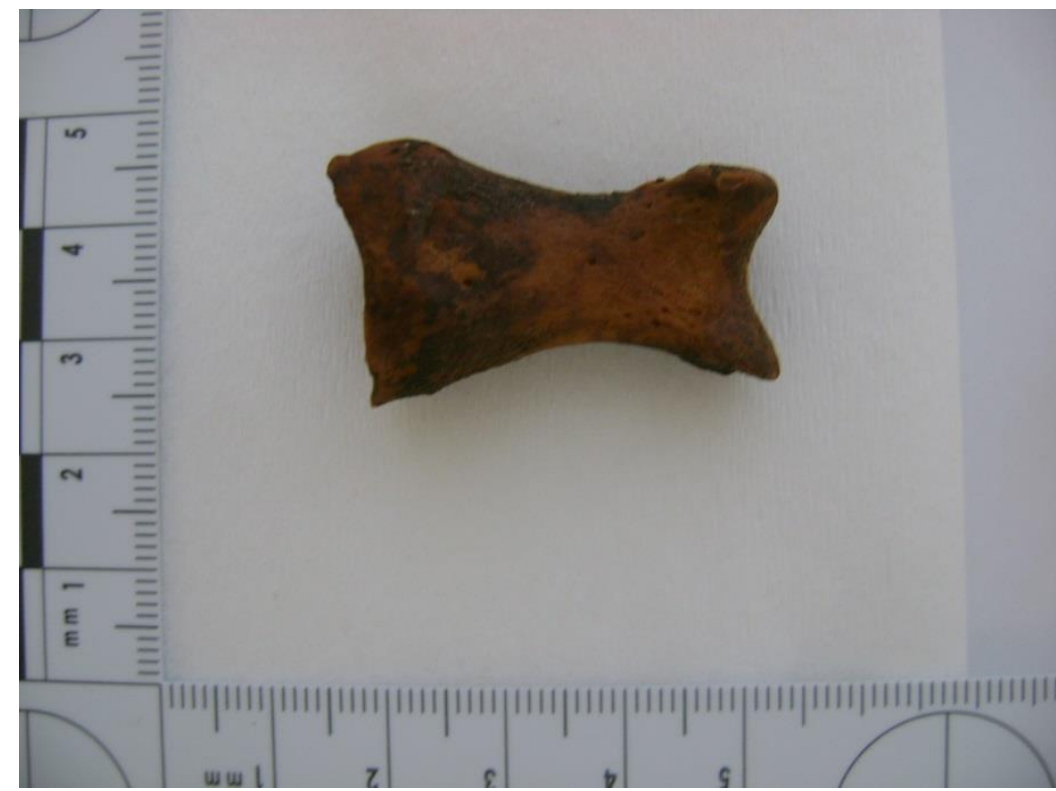

28. ábra: A vizsgálatok során használt csontminta (A fényképet készítette: Pósa Annamária). 


\section{5 Értékelés}

A disszertációban a tuberkulózis különböző régészeti korokból származó emberi maradványokon elvégezhető molekuláris paleopatológiai vizsgálatait mutattam be, összefoglalva e fiatal szakterület eddigi eredményeit, módszertani lehetőségeit. Ez utóbbiakat a doktori kutatási éveim során magyarországi minták elemzésével teszteltem a gyakorlatban. Vizsgálati eredményeim nagy része nemzetközi együttmüködésben, külföldi kutatólaboratórium és külföldi szakmai partnerek közremüködésével született.

A doktori kutatásaim során végzett paleomikrobiológiai vizsgálatok közül jelentőségükben első helyen a tuberkulózis hazai neolit kori előfordulásának molekuláris biológiai konfirmálását kell megemlítenem. A két, általam vizsgált neolit kori embertani széria esetében (Alsónyék-Kanizsa dűlő és Vésztő Mágori-domb) ez volt az első alkalom, hogy tuberkulózis fertőzöttséget molekuláris diagnosztika segítségével állapítottuk meg, és mindkét elemzés jelentős új adatokat szolgáltatott. Továbbá, Alsónyék-Kanizsa dülő esetében a morfológiai és molekuláris eredmények alapján felvetődött, hogy a populáció relatíve rövid időn belül bekövetkezett, eltünése okai között a mycobacteriális fertőzések demográfiai hatása is szerepelhet..

Az eredmények - összhangban a molekuláris biológiai kutatásaimmal párhuzamosan publikált morfológiai adatokkal (Köhler doktori disszertáció, 2012; Köhler et al, 2013),- jelzik, hogy a Mycobacterium tuberculosis fertőzés jelen volt az alsónyéki prehisztorikus populáció temetkezésére használt, általunk tanulmányozott sírcsoportjából előkerült emberi maradványokban (Pósa et al, 2015b). Eredményeim alátámasztják Masson és munkatársai által a közelmúltban közölt magyarországi neolit tuberkulózis-előfordulással kapcsolatos (Masson et al, 2013, 2015), és számos új esettel kiegészítve konfirmálják a MTBC jelenlétét és humánpatogén voltát a mintegy 7000 évvel ezelőtti Kárpát-medencében. Az Alsónyék-Kanizsa dủlő 13-as sírcsoport csontmaradványainak fontosságát a település földrajzi elhelyezkedése, különleges kronológiai időszaka, a klasszikus tbc elváltozások jelenléte és az elért MTBC aDNS eredmények egyaránt felértékelik. A lelőhely további érdekessége annak rendkívül nagy kiterjedése, a mintegy 120 házzal és a temető 2359 sírjával. A tuberkulózis jelenléte és bizonyítottan humánpatogén jellege ebben a populációban kivételes fontossággal bír és 
segíthet megérteni, miért tünik el ez a nagyszámú népesség a régészeti modell alapján rövidnek mondható idő alatt. További vizsgálatok szükségesek annak kiderítése érdekében, hogy megállapítsuk, a $M$. tuberculosis komplex mely tagja fertőzte meg az alsónyéki populációt, hogy a tuberkulózis valóban szerepet játszott-e a későbbi, régészeti adatokból következtetett radikális népesség-csökkenésben. Ennek megválaszolására a jelenleginél pontosabb ismeretek kellenek az Alföld és DélDunántúl neolitikumban élt populációinak tbc-fertőzöttségi rátájáról.

A Tiszai kultúrából származó Vésztő Mágori-domb lelőhelyről származó csontok esetében egy esetben igazoltuk a tbc-baktérium aDNS maradvány jelenlétét, ezzel bizonyítva a lelet mycobacteriális fertőzését.

Mindkét szériával kapcsolatban elmondható, hogy a fogakból is sikeresen izoláltunk bakteriális DNS-t, bizonyítva ezzel, hogy a fogmaradványok jól megőrizhetik a kórokozó DNS-t, igazolva azt a feltételezésünk, hogy a paleomikrobiológiában korábban kevésbé használt fogak is alkalmasak lehetnek mintavételi helyként MTBC vizsgálatok esetén.

A bemutatott adatokból az is látszik, hogy a tbc előfordulása a neolit kori Kárpátmedencében egyáltalán nem sporadikus előfordulású, ritka megbetegedés, hanem a korabeli népesség jelentős érintettségéről beszélhetünk. Mindez összhangban állhat Comas és munkatársai elméletével, miszerint a neolitikum nem elsősorban azzal járult hozzá a tbc előfordulása növekedéséhez, hogy megjelent az állattartás és lehetőség volt az állati kórokozók általi fertőzésre, hanem sokkal inkább azzal, hogy az állattartás és a földmüvelés együttesen hozzájárultak a fertőzhető gazdaszervezetek számának emelkedéséhez (Comas et al, 2013).

További érdekes vizsgálati témaként szolgálhatnak, ha kiterjesztjük vizsgálatainkat a 2014-ben Törökbecse határában feltárt Bordjoš lelöhely csonttani anyagára, ill. az Alsónyék-Bátaszéken feltárt Starčevo-kultúrából származó csonttani maradványokra is. A fentiekből kapott információkkal kibővíthetjük a Kárpát-medence neolitikumból származó vizsgálati anyagát, és szélesíthetjük eddigi információnkat a neolit tuberkulózis fertőzés tekintetében.

A bronzkorból és avar korból származó minták esetén nem tudtuk igazolni a fertőzöttséget, ami arra enged következtetni, hogy az aDNS nagymértékben 
degradálódott. Utóbb említett korszakokból azonban lényegesen kevesebb minta vizsgálatára nyílt lehetöségem, így az esetszámok növelésével talán a kutatás eredményessége is javítható a jövőben. Ez annál is inkább indokolt, mert más lelőhelyek vonatkozásában rendelkezünk jelentős tbc fertőzöttséget jelző avar kori adatokkal (Molnár et al, 2015), és biztosan reprodukálható, jó DNS-megtartottságot jelző tbc-paleomikrobiológiai eredményekkel (Pálfi et al, 2015).

A kora Árpád-korból származó győri temető egy jellegzetes tbc-s eredetü morfológiai elváltozásokat mutató csontvázát vontuk be paleomikrobiológiai vizsgálatainkba - ebből a szériából ez volt az első alkalom, hogy a tuberkulózis fertőzés jelenlétét vizsgálhattuk molekuláris diagnosztika segítségével. Ennek során igazoltuk az aDNS fertőzöttséget a csontvázlelet mindkét mintavételi helyéről. A vizsgálatok jelen fázisában ebben az esetben még nem vontunk be fogakat mintaként, de a későbbiekben erre is kísérletet teszünk.

Már korábbi tanulmányokból is vannak adataink a MTBC fertőzöttségre a bácsalmás-óalmási késő-középkori szériából, az előzetes paleoepidemiológiai vizsgálatok azonban az újabb eredményekhez képest alacsonyabb előfordulási arányokat sugalltak. A különbség a régebbi vizsgálatok koncepciójával magyarázható: amíg korábban a tipikus (krónikus) elváltozási formákra koncentráltak a kutatók, addig a legújabb felmérések során az összes atipikus elváltozás feljegyzésre került. Molekuláris tesztjeinket így már egy bővebb adatbázishoz tudtuk társítani. Az új vizsgálati megközelítésnek köszönhetően számos egyén azonosítható potenciális tbcfertőzöttként, és az egymást komplementer módon kiegészítő morfológiai és paleomikrobiológiai eredmények világosan jelzik, hogy a gümőkóros megbetegedés gyakori lehetett ebben az endogám, 17. századi népességben. A bácsalmási széria csontvázainak mintegy felénél kimutatható a csontokon valamilyen, feltételezhető tuberkulózisra utaló morfológiai jel: ez megkönnyítette a molekuláris vizsgálatoknál a sikeresebb mintavételt. Ebben a szériában is sikeresen igazoltuk a fogakból a mikrobiális DNS jelenlétét. A teljes széria biomolekuláris vizsgálatát, annak rendkívüli költség-, és időigénye miatt nem végezhettük el, de a populáció magas tbc-fertőzöttségi rátája így is igazolást nyert. A disszertációban, ill. az ehhez szorosan kapcsolható publikációban (Pósa et al, 2015a) közölt adatok alátámasztják több korábbi tanulmány 
adatait, melyek már a bácsalmási széria magas tbc prevalenciáját sejtették (Haas et al, 2000; Pálfi és Ardagna, 2002; Zink et al, 2007). A spoligotyping különböző típusú MTBC fertőzéseket jelzett a szériában, de a degradáltsági fok miatt pontos Mycobacterium fajmeghatározást (M. bovis, M. tuberculosis) nem tett lehetővé, így azt csak megerősítő vizsgálatként kezelhettük.

Az újkorból, a páratlan váci múmia gyüjteményből egy egyén (Sándor Terézia) bőr-maradványaiból igazoltuk a MTBC fertőzést. Ebben az esetben a fogból sikertelen volt a DNS-izolálás kísérlete, de mivel a szériából összesen egy egyént és összesen egy fogmintát vizsgáltunk, a megtartási lehetőségekkel kapcsolatban nem vonhatunk le messzemenő következtetéseket.

A disszertációban közölt szériák esetében a szekvenálási eljárás elvégzésére, anyagi korlátok miatt, egyelőre nem volt lehetőségünk. Jövőbeni terveink között mindenképpen szerepel azok megvalósítása.

A szériák azon eseteiben (Alsónyék Kanizsa dủlő 13-as sírcsoport ID 422, Bácsalmás-Óalmás 326-os, 438-as és 481-es sírok), ahol nem volt morfológiai elváltozás, de DNS-szinten már igazolni tudtuk a tbc-fertőzöttség tényét, elmondható, hogy vélhetően előbb halálozott el az egyén, mint hogy a betegség valamilyen nyoma megmutatkozhatott volna a csontokon.

Az adott korszakokban bizonyítottuk a tuberkulózis fertőzöttséget. Jól megfigyelhető, hogy az emberi társadalmat végigkíséri a betegség - tanulmányaink alapján bizonyíthatóan legalább 7 ezer éve. Már az újkőkorban is jelen volt hazánk területén a gümőkór, így érdekes vizsgálati téma lehetne, ha még korábbi korszakok vizsgálatára is lehetőségünk nyílna a következő évek során.

Vizsgálataink rávilágítottak arra is, hogy a mycobacteriális DNS megőrződése valamivel jobb a hosszúcsontok és a fogak esetében, mint a csigolyákban vagy a bordákban. Ugyanakkor arra is rámutatnak a kapott adatok, hogy milyen fontos a megfelelő minta kiválasztása, a helyszínen történő párhuzamos mintavétel: egy-egy egyén esetében a hosszúcsontok és fogak párhuzamos alkalmazása a molekuláris vizsgálatok során. A hosszúcsontok mélyen fekvő kompakt csonrétegeiből és a fogakból 
történő párhuzamos mycobacteriális aDNS-kimutatás nagyon jó eséllyel igazol valóban MTBC eredetű fertőzést - morfológiai tünetekkel párosulva pedig elenyésző szintre csökkenti a MOTT-eredetű fals-pozitivitási kockázatot.

Annak érdekében, hogy vizsgálataink során még reprezentatívabb eredményeket kaphassunk, kiemelt fontosságú a pontos és körültekintő mintavételezés, hiszen egy populáció szintjén nem szükséges az összes egyén vizsgálata. A jövőben további vizsgálatokra, ill. új generációs szekvenálási technikák bevonására lesz szükség, hogy pontosabb képet kaphassunk az eddig vizsgált szériák és jövőben tanulmányozni kívánt leletegyüttesek esetében. A módszerrel korlátozható, ill. kizárható lesz a kontamináció veszélye, megvalósulhat a talajban lévő mycobacteriumok és a humánpatogén Mycobacterium fajok pontosabb elkülönítése, és az egykori tuberkulózis DNS jelenlétének konfirmálásán túl lehetőség nyílik az ősi törzsek karakterizálására, evolúciós kérdéseik tisztázására is. 


\section{Köszönetnyilvánítás}

Köszönetemet szeretném kifejezni témavezetőimnek, Dr. Pálfi Györgynek és Dr. Mende Balázs Gusztávnak, hogy iránymutatásukkal, meglátásaikkal, észrevételeikkel elősegítették munkám megvalósulását és hosszú éveken át biztosították számomra a doktori kutatómunka feltételeit korábban az SZTE Embertani Tanszékén, később az MTA BTK, Régészeti Intézet Archeogenetikai Laboratóriumában. Kiemelt szinten kell megköszönnöm külföldi mentoromnak, Prof. Dr. Albert Zink intézetvezetőnek, hogy összesen hat tanulmányút keretében lehetőséget biztosított számomra a paleomikrobiológiai vizsgálati módszerek elsajátításához és a szükséges elemzések elvégzéséhez a bolzanoi EURAC Research Institute for mummies and Iceman aDNS laboratóriumában.

Paleomikrobiológiai kutatómunkám és az ahhoz szükséges kompetenciák elsajátítása nem valósulhatott volna meg a három, fentiekben említett intézményi egység munkatársainak segítsége nélkül. Köszönettel tartozom korábbi PhD-ösztöndíjas kutatóhelyem, az SZTE Embertani Tanszék egykori és jelenlegi munkatársainak, Dr. Molnár Erikának, Dr. Bereczki Zsoltnak, Dr. Pintér Zoltánnak, Dr. Kajdocsi Lovász Gabriellának, Spekker Olgának, Rovó Jánosnak, Dunai Józsefnének, Kóger Viktóriának, akik munkám során támogattak és közösségük tagja lehettem. Köszönettel tartozom Dr. Wicker Erikának a közös munkáért. Nagyon sok segítséget kaptam jelenlegi munkahelyem, az MTA BTK, Régészeti Intézet Archeogenetikai Laboratóriumában dolgozó kollégáimtól, amit hálásan köszönök Dr. Széchényi-Nagy Annának, Csáky Veronikának, Bódis Viktóriának, valamint a Régészeti Intézetben dolgozó régész és antropológus kollégáknak, különös tekintettel Dr. Köhler Kittinek, Dr. Csiky Gergelynek, Osztás Anettnak, hogy szakmai, ill. baráti tanácsaikkal segítették munkámat. Továbbá köszönöm a MTA BTK, Régészeti Intézet munkatársainak, hogy baráti tanácsokkal, beszélgetésekkel éreztetik velem, hogy egy nagyszerü közösség tagja lehetek. Külön köszönöm a technikai segítséget Vindus Melindának és Sternád Vilmosnak. Nagyon köszönöm a EURAC Research, Institute for mummies and Iceman (Bolzano) összes dolgozójának az együttmüködését, különös tekintettel Dr. Frank 
Maixner, Dr. Giovanna Cipollini, Christina Wurst, Niall O'Sullivan, Alice Paladin segítségét.

Ezúton is szeretném megköszönni a Magyar Természettudományi Múzeum Embertani Tárának, különös tekintettel Dr. Pap Ildikónak, hogy vizsgálataimhoz rendelkezésemre bocsátották Sándor Terézia maradványait. Köszönöm Dr. Hegedüs Ernőnek, hogy hasznos tanácsokkal látott el. Köszönöm Jakusné Dr. Harnos Évának a segítségét. Szeretném megköszönni Dr. Szarka Ildikónak, hogy megosztotta velem szakmai tapasztalatait. S köszönöm az összes együttmüködő partnernek a munkáját, akikkel az elmúlt évek során együtt dolgozhattam. Hálával és köszönettel tartozom a Családomnak, hogy mindig mellettem álltak és támogatták tanulmányaimat. 


\section{Irodalomjegyzék}

Abadia E., Zhang J., Ritacco V., Kremer K., Ruimy R., Rigouts L., Gomes H. M., Elias A. R., Fauville-Dufaux M., Stoffels K., Rasolofo-Razanamparany V., Garcia (de) Viedma D., Herranz M., Al-Hajoj S., Rastogi N., Garzelli C., Tortoli E., Suffys P. N., (van) Soolingen D., Refrégier G., Sola Ch. (2011): The use of microbeadbased spoligotyping for Mycobacterium tuberculosis complex to evaluate the quality of the conventional method: Providing guidelines for Quality Assurance when working on membranes. BMC Infect Dis. 2011; 11: 110. doi: $10.1186 / 1471-2334-11-110$

Albeker M (1970): Győr-Pósdomb (Nr.105). Régészeti Füzetek Ser I. No. 23 (1970) 64.

Albeker M (1970a): Győr-Pósdomb. Archaeologiai Értesitö (1970a) 97316.

Ammerman A.J., Cavalli-Sforza L. (1973): A population model for the diffusion of early farming in Europe. In: The Explanation of Culture Change. Duckworth, London, pp. 343-357.

Ammerman A.J., Cavalli-Sforza L.L. (1984): The Neolithic transition and the genetics of populations in Europe. Princeton University Press, Princeton (New Jersey).

Anders A, Siklósi Zs (eds) (2012): The First Neolithic Sites in Central/South-East European Transect. Volume III. The Körös Culture in Eastern Hungary. British Archaeological Reports International Series 2334. Archaeopress. Oxford

Aranaz, A., Liebana, E., Mateos, A. \& 8 other authors (1996): Spacer oligonucleotide typing of Mycobacterium bovis strains from cattle and other animals: a tool for studying epidemiology of tuberculosis. J Clin Microbiol 34, 2734-2740.

Az Emberi Erőforrások Minisztériuma Egészségügyért Felelős Államtitkárságának egészségügyi szakmai irányelve a tuberkulózis prevenciójáról, diagnosztikájáról, terápiájáról és gondozásáról 2015. EüK. 18. szám EMMI szakmai irányelv 
Baker B. J. (1999): Early manifestetion of tuberculosis in the skeleton. In Pálfi Gy, Dutour O, Deák J, Hutás I eds., Tuberculosis Past and Present. TB Foundation, Golden Book Publisher Ltd., 301-311.

Baker O, Lee OY, Wu HH, Besra GS, Minnikin DE, Llewellyn G, Williams CM, Maixner F, O’Sullivan N, Zink A, Chamel B, Khawam R, Coqueugniot E, Helmer D, Le Mort F, Perrin P, Gourichon L, Dutailly B, Pálfi G, Coqueugniot H, Dutour O (2015): Human tuberculosis predates domestication in ancient Syria. Tuberculosis 95 (Suppl 1):S4- S12. DOI: 10.1016/j.tube.2015.02.001

Bánffy E, Marton T, Osztás A (2010): Early Neolithic settlement and burials at Alsónyék-Bátaszék. In: Neolithization of the Carpathian Basin: Northernmost distribution of the Starčevo/Körös culture (ed. Janusz K. Kozłowski and Pál Raczky), Kraków-Budapest 37-51.

Barker G. (1985): Prehistoric farming in Europe. Cambridge University Press, Cambridge.

Baron H., Hummel S., Herrmann B. (1996): Mycobacterium tuberculosis complex DNA in ancient human bones. J Archaeol Sci 23: 667-671.

Bartels P. (1907): Tuberculose in der J $\square$ ngeren Steinzeit. Archiv fur Anthropologie 6:243-255

Bathurst RR, Barta JL (2004): Molecular evidence of tuberculosis induced hypertrophic osteopathy in a 16th-century Iroquoian dog. J Archaeol Sci 31:917-925.

Bereczki Zs., Paja L., Lovász G., Maczel M., Molnár E., Marcsik A., Pálfi Gy. (2009): New infectious conditions from Bácsalmás-Óalmás, Hungary - Possible cases of skeletal TB. Pálfi, Gy., Molnár, E., Bereczki, Zs., Pap I. (Eds): Des lésions du passé aux diagnostics modernes, Szeged University Press 46-47.

Bertók G, Gáti Cs (2014): Régi idők - új módszerek. Roncsolásmentes régészet Baranya megyében 2005-2013. Archaeolingua: Budapest - Pécs 
Binford L. R. (1968): Post-Pleistocene adaptations. In New Perspectives in Archaeology, L. R. Binford and S. R. Binford, eds. Chicago: Aldine, 313-342.

(de) Boer A. S., Blommerde B., de Haas P. E. W, Sebek M. M. G. G., Lambregts-van Weezenbeek K. S. B., Dessens M., (van) Soolingen D. (2002): False-Positive Mycobacterium tuberculosis Cultures in 44 Laboratories in The Netherlands (1993 to 2000): Incidence, Risk Factors, and Consequences. J Clin Microbiol. 2002 Nov; 40(11): 4004-4009.doi: 10.1128/JCM.40.11.4004-4009.2002

Bogucki P., Grygiel R. (1993): The first farmers of Central Europe: a survey article. Journal of Field Archaeology 20, 399-426.

Boritsch EC., Supply P., Honoré N., Seeman T., Stinear TP., Brosch R. (2014): A glimpse into the past and predictions for the future: the molecular evolution of the tuberculosis agent. Molecular Microbiology, 93 (5): 835-852

Bos K. I., Harkins K. M., Herbig A., Coscolla M., Weber N., Comas I., Forrest S. A., Bryant J. M., Harris S. R., Schuenemann V. J., Campbell T. J., Majander K., Wilbur A. K., Guichon R. A., Steadman D. L. W., Cook D. C., Niemann S., Behr M. A., Zumarraga M., Bastida R., Huson D., Nieselt K., Young D., Parkhill J., Buikstra, J. E. Gagneux S, Stone A. C., Krause J. (2014): PreColumbian mycobacterial genomes reveal seals as a source of New World human tuberculosis. Nature 514, 494-497 (23 October 2014) doi:10.1038/nature13591

Bos K. I., Jäger G, Schuenemann V.J., Vågene A.J., Spyrou M. A., Herbig A., Nieselt K., Krause J. (2015): Parallel detection of ancient pathogens via array-based DNA capture. Phil Trans R. Soc B. 370: 20130375. https://doi.org/10.1098/rstb.2013.0375

Bouwman AS, Kennedy SL, Müller R, Stephens RH, Holst M, Caffell AC, Roberts CA, Brown TA. (2012): Genotype of a historic strain of Mycobacterium tuberculosis. Proc Natl Acad Sci $U$ S A 2012 Nov 6;109(45):18511-6. doi: 10.1073/pnas.1209444109. Epub 2012 Oct 22. 
Braun M., Collins Cook D., Pfeiffer S. (1998): DNA from Mycobacterium tuberculosis complex identified in North American, pre-Columbian human skeletal remains. Journal of Archaeological Science 25, 271-277

Brisse S., Supply P., Brosch R., Vincent V., Gutierrez M.C. (2006): “A reevaluation of M. prototuberculosis": Continuing the debate. PLoS Pathog 2(9): e95. DOI: 10.1371/journal.ppat.0020095.

Brites D., Gagneux S. (2015): Co-evolution of Mycobacterium tuberculosis and Homo sapiens. Tuberculosis Volume 264, Issue 1, pages 6-24, March 2015

Brosch R, Gordon SV, Marmiesse M, Brodin P, Buchrieser C, Eiglmeier K, Garnier T, Gutierrez C, Hewinson G, Kremer K, Parsons LM, Pym AS, Samper S, Soolingen (van) D, Cole ST (2002): A new evolutionary scenario for the Mycobacterium tuberculosis complex. Proc Natl Acad Sci USA. 2002; 99(6).

Burger J, Thomas MG (2011): The Palaeopopulationgenetics of Humans, Cattle and Dairying in Neolithic Europe. In: Pinhasi R, Stock J (eds) Human Bioarchaeology of the Transition to Agriculture. Wiley Blackwell, Chichester, UK, pp 371-384

Campana MG, Robles García N, Rühli FJ, Tuross N. (2014): False positives complicate ancient pathogen identifications using high-throughput shotgun sequencing. BMC Res. Notes 7:111. 10.1186/1756-0500-7-111.

Camus J-C., Pryor M. J., Médigue C., Cole S. T. (2002): Re-annotation of the genome sequence of Mycobacterium tuberculosis H37Rv. Microbiology (2002), 148, $2967-2973$

Chan JZ, Sergeant MJ, Lee OY, Minnikin DE, Besra GS, Pap I, Spigelman M, Donoghue HD, Pallen MJ. (2013): Metagenomic analysis of tuberculosis in a mummy. Comment in N Engl J Med. 2013 Oct 17; 369 (16): 1572.

Chan E. Y. (2009): Next-Generation Sequencing Methods: Impact of Sequencing Accuracy on SNP Discovery. Methods Mol Biol 578:95-111.

Childe V. G. (1959): A civilizáció bölcsője. Gondolat, Budapest, 1959. 
Cockburn A. (1963): The evolution and eradication of infectious disease. Johns Hopkins Press, Baltimore, 1963.

Cole ST, Brosch R, Parkhill J, Garnier T, Churcher C, Harris D, Gordon SV, Eiglmeier K, Gas S, Barry CE ,Tekaia F, Badcock K, Basham D, Brown D, Chillingworth T, Connor R, Davies R, Devlin K, Feltwell T, Gentles S, Hamlin N, Holroyd S, Hornsby T, Jagels K, Krogh A, McLean J, Moule S, Murphy L, Oliver K, Osborne J, Quail MA, Rajandream MA, Rogers J, Rutter S, Seeger K, Skelton J, Squares R, Squares S, Sulston JE, Taylor K, Whitehead S, Barrell BG (1998): Deciphering the biology of Mycobacterium tuberculosis from the complete genome sequence. Nature 1998; 393, 537-544.

Comas I., Coscolla M., Luo T., Borrell S., Holt K. E., Kato-Maeda M., Parkhill J., Malla B., Berg S., Thwaites G., Yeboah-Manu D., Bothamley G., Wei J. M L., Bentley S., Harris S. R., Niemann S., Diel R., Aseffa A., Gao Q., Young D., Gagneux S. (2013): Out-of-Africa migration and Neolithic co-expansion of Mycobacterium tuberculosis with modern humans. Nat Genet. 45(10): 11761182. Published online 2013 Sep 1. doi: 10.1038/ng.2744

Cooper A., C. Mourer-Chauvire G. K. Chambers A. von Haeseler, A. C. Wilson, and S. PA“ A“ BO. (1992): Independent origins of New Zealand moas and kiwis. Proc. Natl. Acad. Sci. USA 89:8741-8744.

Coqueugniot H, Dutailly B, Desbarats P, Boulestin B, Pap I, Szikossy I, Baker O, Montandon M, Panuel M, Karlinger K, Kovács B, Kristóf LA, Pálfi Gy, Dutour O (2015): Three-dimensional imaging of past skeletal TB: from lesion to process. Tuberculosis 95: S73-S79. DOI: 10.1016/j.tube.2015.02.004.

Coros A., E. DeConno, K. M. Derbyshire. (2008): IS6110, a Mycobacterium tuberculosis complex-specific insertion sequence, is also present in the genome of Mycobacterium smegmatis, suggestive of lateral gene transfer among mycobacterial species. Journal of Clinical Microbiology 190: 3408-3410. 
Coscolla M, Gagneux (2014): Consequences of genomic diversity in Mycobacterium tuberculosis. Semin Immunol. 2014 Dec;26(6):431-44. doi: 10.1016/j.smim.2014.09.012. Epub 2014 Oct 22.

Crubézy E, Ludes B, Poveda JD, Clayton J, Crouau-Roy B, Montagnon D (1998): Identification of Mycobacterium DNA in an Egyptian Pott's disease of 5,400 years old. C R Acad Sci III-Vie 321:941-951.

Dabney J., Meyer M., Pääbo S. (2013): Ancient DNA Damage, Cold Spring Harb Perspect Biol. 2013 Jul 1;5(7). pii: a012567. doi: 10.1101/cshperspect.a012567.

Daffé M. (2015): The cell envelope of tubercle bacilli. Tuberculosis (Edinb). 2015 Jun;95 Suppl 1:S155-158. doi: 10.1016/j.tube.2015.02.024. Epub 2015 Mar 13.

Dang La V, Aboudharam G, Raoult D, Drancourt M.: (2008): Dental Pulp as a Tool for the Retrospective Diagnosis of Infectious Diseases. Paleomicrobiology Past Human Infections Chapter 11 pp. 175-196

Dávid L. (1970): Jelentés a Győr-Sopron megyei múzeumi szervezet 1969. évi müködéséről. Arrabona 12 (1970) 391-406.

Dávid L. (1971): Jelentés a Győr-Sopron megyei múzeumi szervezet 1970. évi müködéséröl. Arrabona 13 (1971) 505-517.

Dávid L. (1972): Jelentés a Győr-Sopron megyei múzeumi szervezet 1971. évi müködéséröl. Arrabona 14 (1972) 435-451.

Deguilloux MF, Pemonge M H, Dubut V, Hughes S, Hänni C, Chollet, L, Conte, E, Murail, P (2011): Human ancient and extant mtDNA from the Gambier Islands (French polynesia): evidence for an early melanesian maternal contribution and new perspectives into the settlement of easternmost polynesia. Am J Phys Anthropol 144:248-57.

Dennel R. (1992): The origin of crop agriculture in Europe. In: Cowan, C.W., Watson, P.J. (Eds.), The Origins of Agriculture. An International Perspective. Smithsonian Institution Press, Washington, pp. 71-100. 
Domogalla J., Prodinger W.M., Blum H., Krebs S., Gellert S., Müller M., Neuendorf E.,Sedlmaier F.,Büttner M.: (2013): Region of difference 4 in alpine Mycobacterium caprae isolates indicates three variants. J. Clin. Microbiol. 51, $1381-1388$

Donoghue H.D. (2011): Insights gained from palaeomicrobiology into ancient and modern tuberculosis. Clinical Microbiology and Infection. Volume 17, Issue 6, pages 821-829, June 2011.

Donoghue H.D. (2008): Paleomicrobiology of Tuberculosis. In Raoult D, Drancourt M eds., Paleomicrobiology: Past Human Infections. SpringerVerlag, BerlinHeidelberg, pp. 75-99.

Donoghue H.D. (2009): Human tuberculosis - an ancient disease, as elucidated by ancient microbial biomolecules. Microbes Infect 2009; 11:1156-1162.

Donoghue H.D. (2017): Insights gained from ancient biomolecules into past and present tuberculosis-a personal perspective. International Journal of Infectious Diseases 56: $176-180$.

Donoghue H.D., Pap I., Szikossy I., Spigelman M. (2011): Detection and Characterization of Mycobacterium tuberculosis DNA in 18th Century Hungarians with Pulmonary and Extra-pulmonary Tuberculosis. Yearbook of Mummy Studies, Verlag Dr. Friedrich Pfeil 1 (8), 51-56.

Donoghue H.D., Spigelman M., Zias J., Gernaey-Child A. M., Minnikin D. E. (1998): Mycobacterium tuberculosis complex DNA in calcified pleura from remains 1400 years old. Lett Appl Microbiol 27:265-269.

Donoghue H.D., Uberlaker D.H., Spigelman M., (1999): The use of palaeomicrobiological techniques in a current forensic case. In: Pálfi, G., Dutour, O., Deák, J., Hutás, I. (Eds.), Tuberculosis Past and Present. Golden Book Publisher Ltd, Tuberculosis Foundation, pp. 363-368.

Donoghue H.D., Marcsik A., Matheson C., Vernon K., Nuorala E., Molto J., Greenblatt Ch., Spigelman M. (2005): Co-infection of Mycobacterium tuberculosis and 
Mycobacterium leprae in human archaeological samples - a possible explanation for the historical decline of leprosy. Proceedings of The Royal B: Biological Sciences. 272 (1561) 389-394.

Donoghue H.D., Spigelman M., O’Grady J., Szikossy I., Pap I., Lee OYC., Wu HHT., Besra GS., Minnikin DE. (2015): Ancient DNA analysis - An established technique in charting the evolution of tuberculosis and leprosy. Tuberculosis; 95, S1: S140-S144. doi: 10.1016/j.tube.2015.02.020.

Drancourt M, Aboudharam G, Signoli M, Dutour O, Raoult D (1998): Detection of 400year-old Yersinia pestis DNA in human dental pulp: An approach to the diagnosis of ancient septicemia. Proc Natl Acad Sci USA Vol. 95:12637-12640

Drancourt M, Raoult D (2005): Palaeomicrobiology: current issues and perspectives. Nat Rev Microbiol 3:23-35.

Drancourt M, Roux V, Dang LV (2004): Genotyping, Orientalis-like Yersinia pestis, and plague pandemics. Emerg Infect Dis 10:1585-1592

Drancourt M, Signoli M, Dang LV (2007): Yersinia pestis Orientalis in remains of ancient plague patients. Emerg Infect Dis 13:332-333.

Driscoll JR (2009): Spoligotyping for molecular epidemiology of the Mycobacterium tuberculosis complex. Methods Mol Biol. 2009;551:117-28. doi: 10.1007/978-160327-999-4_10

Dutour O, Pálfi G, Brun JP, Bérato J, Panuel M, Haas CJ, Zink A, Nerlich AG (1999): Morphological, paleoradiological and paleo-microbiological study of a French medieval case of tuberculous spondylitis with cold abscess. In Pálfi Gy, Dutour O, Deák J, Hutás I eds., Tuberculosis Past and Present. TB Foundation, Golden Book Publisher Ltd, 395- 400.

Dutour O, Pálfi G, Charmel B, Baker O, Coqueugniot H, Stordeur D, Le Mort F, Perrin P. (2010): Paleopathology of Pre and Early Neolithic Tuberculosis: Why so few cases? Abstracts of the 10th International Conference on Ancient DNA and Related Biomolecules Munich 10.10.2010 - 13.10.2010. 
Eisenach KD, Cave MD, Bates JH, Crawford JT. (1990): Polymerase chain reaction amplification of a repetitiveDNA sequence specific for Mycobacterium tuberculosis. J Infect Dis; 161:977-81.

Eisenach KD, Sifford M.D., Cave MD, Bates JH, Crawford JT. (1991): Detection of Mycobacterium tuberculosis in Sputum Samples Using a Polymerase Chain Reaction. American Review of Respiratory Disease Vol 144. pp. 1160-1163

Faerman M, Jankauskas R, Gorski A, Bercovier H, Greenblatt CL. (1999): Detecting Mycobacterium tuberculosis DNA in medieval skeletal remains from Lithuana. In Pálfi Gy, Dutour O, Deák J, Hutás I eds., Tuberculosis: Past and Present. Golden Book Publisher Ltd, 1999; 371-376.

Faerman M, Jankauskas R, Gorski A, Bercovier H, Greenblatt CL. (1997): Prevalence of human tuberculosis in a medieval population of Lithuania studied by ancient DNA analysis. Ancient Biomolecules 1997; 1:205-214.

Fang Z., Kenna D. T., Doig C., Smittipat D. N., Palittapongarnpim P., Watt B., Forbes K. J. (2001): Molecular evidence for Independent occurrence of IS6110 insertion at the same site of the genome of Mycobacterium tuberculosis in different clinical isolates. J. Bacteriol 2001 Sept; 183(18): 5279-5284. doi: 10.1128/JB.183.18.5279-5284.2001

Farkas L. Gy, Lipták P. (1971): A Tápé melletti feltárt késő bronzkori temető antroplógiai értékelése. Anthtop. Közl. 15. (1971) 1. 3-18.

Figueroa-Munoz J., Ramon-Pardo P. (2008): Tuberculosis control in vulnerable groups. Bulletin of the World Health Organization Past issues Volume 86: 2008 Volume 86, Number 9, September 2008, 657-736

Filliol I., Motiwala A.S., Cavatore M., Qi W., Hazbo MH., Bobadilla del Valle M., Fyfe J., García-García L., Rastogi N., Sola C., Zozia T., Guerrero MI., León CI., Crabtree J., Angiuoli S., Eisenach KD., Durmaz R., Joloba ML., Rendón A., Sifuentes-Osornio J., Ponce de León A., Cave DM., Fleischmann R., Whittam TS., Alland D. (2006): Global phylogeny of Mycobacterium tuberculosis based on 
single nucleotide polymorphism (SNP) analysis: insights into tuberculosis evolution, phylogenetic accuracy of other DNA fingerprinting systems, and recommen-dations for a minimal standard SNP set. J Bacteriol, 188: 759-772.

Fletcher H.A., Donoghue H.D., Taylor G.M., van der Zanden A.G.M., Spigelman M. (2003a): Molecularanalysis of Mycobacterium tuberculosis DNA from a family of 18th century Hungarians. Microbiology 149: 143-151.

Fletcher H. A., Donoghue H. D., Holton J., Pap I., Spigelman M. (2003b): Widespread occurrence of Mycobacterioum tuberculosis DNA 18-19th Century Hungarians. Am J Phys Anthrop 120: 144-152.

Gernaey A. M., Minnikin D. E., Copley M. S., Ahmed A. M. S., Robertson D. J., Nolan J., Chamberlain A. T., (1999): Correlation of the occurrence of mycolic acids with tuberculosis in archaeological population. Tuberculosis: Past and present. TB Foundation, Szeged \& Golden Book Publisher, Budapest, 273-283

Gilbert M.T.P., Hansen A.J., Willerslev E., Barnes I., Rudbeck L., Lynnerup N., Cooper A. (2003a): Characterisation of genetic miscoding lesions caused by post-mortem damage. Am. J. Hum. Genet. 72:48-61.

Gilbert M.T.P., Willerslev E., Hansen A.J., Barnes I., Rudbeck L., Lynnerup N., Cooper A. (2003b): Distribution patterns of post-mortem damage in human mitochondrial DNA. Am. J. Hum. Genet. 72:32-47.

Gilbert MT, Cuccui J, White W, Lynnerup N, Titball RW, Cooper A.: Prentice MB. (2004): Absence of Yersinia pestis-specific DNA in human teeth from five European excavations of putative plague victims. Microbiology. Feb;150(Pt 2):341-54.

Gilbert MTP, Rudbeck L, Willerslev E, Hansen AJ, Smith C,. Penkman KEH, Prangenberg K, Nielsen-Marsh CM, Jans ME, Arthur P, Lynnerup N, TurnerWalker G, Biddle M, Kjolbye-Biddle B, Collins MJ (2005): Biochemical and physical correlates of DNA contamination in archaeological human bones and teeth excavated at Matera, Italy. J Archaeol Sci 32:785-793. 
Gordon S. V., Behr M. A. (2015): Comparative Mycobacteriology of the Mycobacterium tuberculosis complex. Mukundan, H., Chambers, M., Waters, R. and Larsen, M.(eds.). Many Hosts of Mycobacteria: Tuberculosis, Leprosy, and other Mycobacterial Diseases of Man and Animals, CAB International, http://researchrepository.ucd.ie/handle/10197/5858

Gori A, Bandera A, Marchetti G, Degli Esposti A, Catozzi L, Nardi G P, Gazzola L, Ferrario G, van Embden J D A, (van) Soolingen D, Moroni M, Franzetti F (2005): Spoligotyping and Mycobacterium tuberculosis. Emerg Infect Dis. 2005 Aug; 11(8): 1242-1248. doi: 10.3201/1108.040982

Gutierrez MC, Brisse S, Brosch R, Fabre M, Omais B, Marmiesse M, Supply, P., Vincent, V. (2005): Ancient origin and gene mosaicism of the progenitor of Mycobacterium tuberculosis. PLoS Pathogens, 1(1): e5.

Győry T. (1900): Morbus hungaricus, Orvostörténelmi tanulmány, Budapest. A Pesti Lloyd-társulat könyvnyomdája.

H. Simon K. (2003): A dunántúli neolitikum a kezdetektől a Lengyel-kultúra kialakulásáig. In Bartosiewicz L., T. Biró K., Jerem E., Laszlovszky J., Nagy M., Révész L., Vaday A., Vida T., M. Virág Zs., Visy Zs., Wollák K. Magyar régészet az ezredfordulón ISBN 96386291077.

Haak W, Balanovsky O, Sanchez JJ, Koshel S, Zaporozhchenko V, Adler CJ, Der Sarkissian CS, Brandt G, Schwarz C, Nicklisch N,Dresely V, Fritsch B, Balanovska E, Villems R, Meller H, Alt KW, Cooper A. (2010): Ancient DNA from European early neolithic farmers reveals their near eastern affinities. PLoS Biol 8:e1000536.

Haas CJ, Zink A, Molnár E, Marcsik A, Dutour O, Pálfi Gy (1999): Molecular evidence for tuberculosis in Hungarian skeletal samples. In Pálfi Gy, Dutour O, Deák J, Hutás I, eds., Tuberculosis: Past and present. Golden Book Publisher and Tuberculosis Foundation, Budapest-Szeged, 383-391.

Haas C.J., Zink A., Molnár E., Szeimes U., Reischl U., Marcsik A., Ardagna Y., Dutour O., Pálfi Gy., Nerlich A. G. (2000): Molecular evidence for different stages of 
tuberculosis in ancient bone samples from Hungary. American Journal of Physical Anthropology, 113: 293-304.

Haensch S., Bianucci R., Signoli M., Rajerison M., Schultz M., Kacki S., Vermunt M., Weston D. A., Hurst D., Achtman M., Carniel E., Bramanti B. (2010): Distinct Clones of Yersinia pestis Caused the Black Death. PLoS Pathog. 2010 Oct; 6(10): e1001134. Published online 2010 Oct 7. doi: 10.1371/journal.ppat.1001134

Hagelber E, Sykes B, Hedges R. (1989): Ancient bone DNA amplified. Nature 342: 485

Hagelberg E., Thomas M.G., Cook Ch.E., Sher AV, Baryshnikov GF, Lister AM. (1994): DNA from ancient mammoth bones. Nature 370: 333-334.

Hershberg R., Lipatov M., Small PM., Sheffer H., Niemann S., Homolka S., Roach JC., Kremer K., Petrov DA., Feldman MW., Gagneux S. (2008): High functional diversity in Mycobacterium tuberculosis driven by genetic drift and human demography. PLoS Biol, 6: e311.

Hershkovitz I., Donoghue H. D., Minnikin D. E., Besra G. S., Lee O. Y-C., Gernaey A. M., Galili E., Eshed V., Greenblatt C. L, Lemma E., Bar-Gal G. K., Spigelman M., (2008): Detection and Molecular Characterization of 9000-Year-Old Mycobacterium tuberculosis from a Neolithic Settlement in the Eastern Mediterranean. PloSONE, October 2008, 3, 10, e3426.

Hershkovitz I., Greenwald C.M., Latimer B., Jellema L.M., Wish-Baratz S., Eshed V., Dutour O., Rothschild B.M. (2002): Serpens Endocrania Symmetrica (SES): A new term and a possible clue for identifying intrathoracic disease in skeletal populations. Am. J. Phys. Anthropol., 118: 201-216.

Higuchi R., Bowman B., Freiberger M., Ryder O. A., Wilson A. C. (1984): DNA sequences from the quagga, an extinct member of the horse family. Nature, 312. $282-4$

Hochmeister M, Budowle B. (1991): Typing of DNA extracted from compact bone tissue from human remains. J Forensic Sci. 36:1649-1661 
Holl A. F. C. (2015): The Neolithisation Process in the Americas. In: Human origin sites and the World Heritage convention in the Americas, Volume II. 42. Paris, UNESCO; Mexico, UNESCO Office Mexico, 2015. ISBN 978-92-3-100141-3

Holloway KL, Henneberg RJ, de Barros Lopes M, Henneberg M. (2011): Evolution of human tuberculosis: a systematic review and meta-analysis of paleopathological evidence. Homo: internationale Zeitschrift fur die vergleichende Forschung am Menschen 62: 402-458.

Horáčková L, Vargová L, Horváth R, Bartoš M (1999): Morphological, roentgenological and molecular analyses in bone specimens attributed to tuberculosis, Moravia (Czech Republic). In Pálfi Gy, Dutour O, Deák J, Hutás I eds., Tuberculosis Past and Present. TB Foundation, Golden Book Publisher Ltd, 413-417.

Horváth Z., Sövény M., Szénásiné Harton E. (2006): Bácsalmás - Fejezetek egy felsőbácskai kisváros történetéből. Bácsalmás.

Horváth G., Molnár E., Kovács J., Wicker E., Bérato J., Pálfi Gy. (1994): Paleopathological diagnosis and interpretation of seronegative spondylarthropathies from the 17th century. Acta Biologica Szegediensis, 40, 103115.

http://www.illumina.com/documents/products/techspotlights/techspotlight_sequencing. pdf

Jakucs J, Voicsek V. (2015): The northermost distribution of the early Vinča Culture in the Danube valley: a preliminary study from Szederkény-Kukorica-dűlő (Baranya County, southern Hungary). Antaeus 33 (2015) 13-54.

Johnson MM, Odell JA. (2014): Nontuberculous mycobacterial pulmonary infections. $J$ Thorac Dis, 6 (3): 210-220. doi: 10.3978/j.issn.2072-1439.2013.12.24

Juhász E. (1999): Metodikai tanulmány Győr-Pósdomb 10-11. századi temetőjének embertani anyagán. Szakdolgozat. Budapest 1999. 
Kalicz N. (2011): Forschung über die Starčevo-Kultur in Südtransdanubien (Ungarn). In K. Botić, S. Kovačević, D. L. Dizdar (eds.), Panonski prapovijesni osviti. Zbornik radova posvećenih Korneliji Minichreiter uz 65. Obljetnicu života. Institut za arheologiju, Zagreb: 105-129.

Kamerbeek J, Schouls L, Kolk A, van Agterveld M, (van) Soolingen D, Kuijper S, Bunschoten A, Molhuizen H, Shaw R, Goyal M, van Embden J. (1997): Simultaneous detection and strain differentiation of Mycobacterium tuberculosis for diagnosis and epidemiology. J Clin Microbiol, 1997; 35:907-914.

Kapronczay K. (2010): A járványok elleni küzdelem intézményrendszerének kiépítése Magyarországon. In: Kapronczay K. (szerk.): A magyarországi közegészségügy szakterületeinek történetéből, 1876-1944. Magyar Tudománytörténeti Intézet, Semmelweis Orvostörténeti Múzeum, Könyvtár és Levéltár, Budapest, 2010, p. 52.

Karakousis P C, Bishai W R, Dorman S E. (2004): Mycobacterium tuberculosis cell envelope lipids and the host immune response. Cellular Microbiology 6(2), 105116 doi:10.1046/j.1462-5822.2003.00351.x

Kay GL, Sergeant MJ, Zhou Z, Chan JZ-M, Millard A, Quick J, Szikossy I, Pap I, Spigelman M, Loman NJ, Achtman M, Donoghue H D, Pallen M J. (2015): Eighteenth-century genomes show that mixed infections were common at time of peak tuberculosis in Europe. Nat Commun 6: 6717.

Kefi R. (2011): Ancient DNA investigations: a review on their significance in different research fields. International Journal of Modern Anthropology, 4: 61 - 76 doi: 10.4314/ijma.v1i4.4

Kemp BM, Monroe C, and Smith DG (2006): Repeat silica extraction: a simple technique for the removal of PCR inhibitors from DNA extracts. Journal of Archaeological Science 33:1680-1689.

Keyser-Tracqui C, Ludes B. (2005): Methods for the study of ancient DNA. Methods Mol Biol. 2005;297:253-64. 
Kim AJ, Kim K, Choi JH, Choi EH, Jung YJ, Min NY, Lkhagvasuren G, Rhee S, Kim JH, Noh M, Park AJ, Kim KY, Kang Y, Lee KH, Kim KC (2010): Mitochondrial DNA analysis of ancient human bones excavated from Nukdo island, S.Korea. BMB Rep 43:133-9.

Knapp M, Hofreiter M. (2010): Next Generation Sequencing of Ancient DNA: Requirements, Strategies and Perspectives. Genes 2010, 1, 227-243; doi:10.3390/genes 1020227

$\begin{array}{lllll}\text { Korányi } & \text { Bulletin } & \text { (2016) } & \text { évkönyv } & 1 .\end{array}$ http://www.koranyi.hu/tartalom/bulletin/Evkonyv2016.pdf

Köhler K, Mende BG, Pósa A. (2013): The emergence of tuberculosis in Late Neolithic Transdanubia. Hungarian Archaeology. E-JOURNAL, 2013 Summer, http://www.hungarianarchaeology.hu/wpcontent/uploads/2013/08/eng_Kohler_13ny1.pdf

Köhler K, Pálfi Gy, Molnár E, Zalai-Gaál I, Osztás A, Bánffy E, Kirinó K, Kiss KK, Mende BG (2012): A Late Neolithic case of Pott's Disease from Hungary. Int. J. Osteoarchaeol. DOI: 10.1002/oa.225

Köhler K. (2012): A késő neolitikus lengyeli kultúra népességének biológiai rekonstrukciója doktori disszertáció, Eötvös Loránd Tudományegyetem, Természettudományi Kar, Biológiai Intézet, Biológia Doktori Iskola, Budapest, 2012

Köhler K. (2015): A Starčevo kultúra embertani leletei Alsónyék-Bátaszék lelőhelyről. Anthropologiai Közlemények 56, 2015, 3-26.

Krause J, Briggs A W, Kircher M, Maricic T, Zwyns N, Derevianko A, Pääbo S, (2010): A complete mtDNA genome of an early modern human from Kostenki, Russia. Curr Biol 20:231-6.

Krause J., Dear P. H., Pollack J. L., Slatkin M., Spriggs H., Barnes I., Lister A. M., Ebersberger I., Pääbo S., Hofreiter M. (2006): Multiplex amplification of the 
mammoth mitochondrial genome and the evolution of Elephantidae. Nature 439, 724-727 (9 February 2006) | doi:10.1038/nature04432

Lalueza-Fox C. (1996): Physical anthropological aspects of the Mesolithic-Neolithic transition in the Iberian Peninsula. Current Anthropology 37, 689-95.

Latham K. J. (2013): "Human Health and the Neolithic Revolution: an Overview of Impacts of the Agricultural Transition on Oral Health, Epidemiology, and the Human Body". Nebraska Anthropologist. Paper 187. http://digitalcommons.unl.edu/nebanthro/187

Lemma E, Lev-Maor G, Bar-Gal GK, Nasereddin A, Spigelman M, Zink A, Greenblatt C. (2010): Spoligotypes od ancient Mycobacterium tuberculosis development of a data bank. Proceeding of 10th Internatinal Conference on Ancient DNA and Associated Biomolcules (ADNA) Munich, Germany, 10-13

Lovász G, Molnár E, Marcsik A. (2005a): Bácsalmás-Óalmás 16-17. századi temető paleopatológiai vizsgálatának eredményei (2001-2003-as feltárás). In: IV. Kárpátmedencei Biológiai Szimpózium. Előadások összefoglalói. 2005; 153-158.

Lovász G. (2005b): Bácsalmás-Óalmás 16-17. századi temető általános embertani feldolgozása (2001-2003-as feltárás). Diplomamunka. Szeged. 2005.

Lovász G. (2015): A török hódoltság kori idegen etnikumok összehasonlító embertani vizsgálata doktori disszertáció, Szegedi Tudományegyetem, Természettudományi és Informatikai Kar, Biológia Doktori Iskola, Szeged, 2015.

Lovász G., Bereczki Zs., Pálfi Gy., Molnár E. (2009): A possible case of echinococcosis from a late medieval series in Hungary. Pálfi, Gy., Molnár, E., Bereczki, Zs., Pap I. (Eds) : Des lésions du passé aux diagnostics modernes, Szeged University Press 70-71.

Lovász G., Schultz M., Gödde J., Bereczki Zs., Pálfi Gy., Marcsik A., Molnár E. (2013): Skeletal manifestations of infantile scurvy in a late medieval anthropological series from Hungary, Anthropological Science 121(3): 173-185. 
Maczel M. (2003): 'On the Traces of Tuberculosis. Diagnostic criteria of tuberculosis affection of the human skeleton and their application in Hungarian and French anthropological series. PhD Thesis, University of Szeged - University of La Méditerranée, pp. 263 (TTK-49/2004)

Makkay J. (2004): Vésztő-Mágor. Ásatás a szülőföldön. Békés Megyei Múzeumok Igazgatósága, Békéscsaba.

Marcsik A., Molnár E., Ősz B., Donoghue H., Zink A., Pálfi Gy. (2009): Adatok a lepra, tuberculosis és syphilis magyarországi papeopatológiájához. Folia Anthropologica 8., pp. 5-34.

Marton T, Oross K. (2010): Siedlungsforschung in linienbandkeramischen Fundorten in Zentral- und Südtransdanubien - Wiege, Peripherie oder beides? In: Smolnik, R. (Hrsg.): Siedlungsstruktur und Kulturwandel in der Bandkeramik. Beiträge der internationalen Tagung „Neue Fragen zur Bandkeramik oder alles beim Alten?!” Leipzig, 23. bis 24. September 2010. Landesamt für Archäologie, Freistaat Sachsen. Dresden 2012, 220-239.

Masson M, Bereczki Zs, Molnár E, Donoghue HD, Minnikin DE, Lee O-C, Wu HHT, Besra, Bull ID, Pálfi Gy. (2015): 7000 Year-Old Tuberculosis Cases from Hungary Osteological and Biomolecular Evidence. Tuberculosis; 95, S1: S13S17. doi: 10.1016/j.tube.2015.02.007.

Masson M., Molnár E., Donoghue H.D., Besra G.S., Minnikin D.E., Wu H.H.T., Lee O.Y-C., Bull I.D., Pálfi G. (2013): Osteological and Biomolecular Evidence of a 7000-Year-Old Case of Hypertrophic Pulmonary Osteopathy Secondary to Tuberculosis from Neolithic Hungary. PlosONE 8(10): e78252.

Matheson CD, Vernon KK, Lahti A, Fratpietro R, Spigelman M, et al. (2009): Molecular Exploration of the First-Century Tomb of the Shroud in Akeldama, Jerusalem. PLosONE 4(12) e8319. doi10.1371journal. pone.0008319

Mathieson I., Lazaridis I., Rohland N., Mallick S., Patterson N., Roodenberg S. A., Harney E., Stewardson K., Fernandes D., Novak M., Sirak K., Gamba C., Jones E. 
R., Llamas B., Dryomov S., Pickrel J., Arsuaga J. L., Bermúdez de Castro J. M., Carbonell E., Gerritsen F., Khokhlov A., Kuznetsov P., Lozano M., Meller H., Mochalov O., Moiseyev V., Rojo Guerra M. A., Roodenberg J., Vergès J. A., Krause J., Cooper A., Alt K. A., Brown D., Anthony D., Lalueza-Fox C., Haak W., Pinhasi R., Reich, D. (2015): Genome-wide patterns of selection in 230 ancient Eurasians. $\quad$ Nature, 528(7583), 499-503. http://doi.org/10.1038/nature16152

Maxam AM, Gilbert W (1977): "A new method for sequencing DNA". Proc. Natl. Acad.Sci.U.S.A. $74 \quad$ (2):560-4. Bibcode:1977PNAS...74..560M. doi:10.1073/pnas.74.2.560. PMC 392330. PMID 265521.

Mays S, Fysh E, Taylor GM. (2002): Investigation of the link between visceral surface rib lesions and tuberculosis in a medieval skeletal series from England using ancient DNA. Am J Phys Anthropol 119: 27-36.

Medgyesi P. (2014): A konferencia részletes programja: szakmai beszámoló a Nemzeti Kulturális Alap által biztosított, vissza nem térítendő támogatás felhasználásáról (2014. október 21-23.)

Mesterházy K. (1974): Győr-Pósdomb (Nr. 132). Régészeti Füzetek Ser I. No. 27 (1974) 73.

Mészáros P, Paluch T, Szalontai Cs. (2006): Avar kori temetők Kiskundorozsma határában (Előzetes beszámoló az M5-ös autópályán feltárt lelőhelyekröl). Tatabányai Múzeum Tudományos Füzetek 8, 97-109

Meyer M., Kircher M. (2004): Illumina Sequencing Library Preparation for Highly Multiplexed Target Capture and Sequencing. Cold Spring Harb. Protoc.; 2010; doi:10.1101/pdb.prot5448

Minnikin DE, Besra GS, Lee OYC, Spigelman M, Donoghue HD (2011): The interplay of DNA and lipid biomarkers in the detection of tuberculosis and leprosy in mummies and other skeletal remains. In Gill-Frerking G, Rosendahl W, Zink A, 
Piombino-Mascali D eds., Yearbook of Mummy Studies 1, Verlag Dr. Friedrich Pfeil, Münich, Germany, 109-114.

Minnikin DE, Kremer L, Dover LG, Besra GS (2002): The methyl-branched fortifications of Mycobacterium tuberculosis. Chem Biol. 2002 May; 9(5):545-53.

Molnár E, Donoghue HD, Lee OY-C, Wu HHT, Besra GS, Minnikin DE, Bull ID, Llewellyn G, Williams CM, Spekker O, Pálfi Gy. (2015): Morphological and biomolecular evidence for tuberculosis in 8th century AD skeletons from Bélmegyer-Csömöki domb, Hungary. Tuberculosis 95 Suppl 1:S35-41. doi: 10.1016/j.tube.2015.02.032.

Molnár E., Pálfi Gy. (1994): Probable cases of skeletal infections in the 17th century anthropological series of Bácsalmás (Hungary). - Acta Biologica Szegediensis, 40, 117-133.

Mullis K, and Faloona F (1987): Specific synthesis of DNA in vitro via a polymerasecatalyzed chain reaction. Methods Enzymol 155:335-350.

Mullis K, Faloona F, Scharf S, Saiki R, Horn G, and Erlich H (1986): Specific enzymatic amplification of DNA in vitro: the polymerase chain reaction. Cold Spring Harbor Symp Quant Biol 51:263-273.

Müller R, Roberts CA, Brown TA. (2014): Biomolecular identification of ancient Mycobacterium tuberculosis complex DNA in human remains from Britain and Continental Europe. Am J Phys Anthropol, 153(2), 178-189. eScholarID:224339 | DOI:10.1002/ajpa.22417

Müller R, Roberts CA, Brown TA. (2014): Genotyping of ancient Mycobacterium tuberculosis strains reveals historic genetic diversity. Proc Biol Sci, 281(1781), 20133236. eScholarID:224341 | DOI:10.1098/rspb.2013.3236

Müller R., Roberts C.A., Brown T.A. (2015): Complications in the study of ancient tuberculosis: non-specificity of IS6110 PCRs. STAR: Science and Technology of Archaeological Research., 1:1, 1-8, DOI: 10.1179/2054892314Y.0000000002. http://dx.doi.org/10.1179/2054892314Y.0000000002 
Müller R., Roberts C.A., Brown T.A. (2016): Complications in the study of ancient tuberculosis: Presence of environmental bacteria in human archaeological remains. Journal of Archaeological Science 68: 5-11.

Namouchi A, Karboul A, Mhenni B, Khabouchi N, Haltiti R, Ben Hassine R, Louzir B, Chabbou A, Mardassi H (2008): Genetic profiling of Mycobacterium tuberculosis in Tunisia:predominance and evidence for the establishment of a few genotypes. $J$ Med Microbiol 57: 864-872.

Neparáczki E, Török T, Pósa A, Molnár E, Lovász G, Maixner F, Zink A, Dutour O, Pálfi Gy. (2011): Preliminary results from the paleomicrobiological studies of Mycobacterium tuberculosis infection in the Bácsalmás-Óalmás anthropological series. Acta Biologica Szegediensis 55.(1) 2011; 41-45.

Nerlich AG, Haas CJ, Zink A, Szeimes U, Hagedorn HG (1997): Molecular evidence for tuberculosis in an ancient Egyptian mummy. Lancet 350:1404

Nerlich AG, Lösch S (2009): Paleopathology of Human Tuberculosis and the Potential Role of Climate. Interdisciplinary Perspectives on Infectious Diseases 2009, Article ID 437187, 9 pages, 2009. doi:10.1155/2009/437187

Nerlich AG, Marlow S, Zink A. (2010): Ancient DNA analysis of Leprosy and Tuberculosis in a Medieval to Modern Skeletal Series from a Distinct South German Population. Proceeding of 10th Internatinal Conference on Ancient DNA and Associated Biomolcules (ADNA), Munich, Germany, 10-13

Nguyen-Hieu T, Aboudharam G, Drancourt M. (2011): Mini Review: Dental Pulp as a Source for Paleomicrobiology. Bull Int Assoc Paleodont 2011; 5(1):48-54.

Nicklisch N, Maixner F, Ganslmeier R, Friederich S, Dresely V, Meller H, Zink AR, Alt KW (2012): Rib lesions in skeletons from early Neolithic sites in central Germany: on the trail of tuberculosis at the onset of agriculture. Am J Phys Anthropol 2012; 149:391-404.

Oross K, Bánffy E, Osztás A, Marton T, Nyerges ÉÁ, Köhler K, Szécsényi-Nagy A, Alt KW, Bronk Ramsey C, Goslar T, Kromer B, Hamilton D. (2016): The early days 
of Neolithic Alsónyék: the Starčevo occupation. Bericht Der RömischGermanischen Kommission 94: pp. 93-121. (2013) [2016]

Oross K, Siklósi Zs. (2012): Relative and absolute chronology of the Early Neolithic in the Great Hungarian Plain. In: Anders, A.-Siklósi, Zs. (eds): The First Neolithic Sites in Central/South-East European Transect. Volume III. The Körös Culture in Eastern Hungary. British Archaeological Reports International Series 2334. Archaeopress. Oxford, 129-159.

Ortner D. J. (1999): Paleopathology: Implications for the history and evolution of tuberculosis. In: Tuberculosis: Past and Present. 253-261

Ortner D. J. (2003): Identification of pathological conditions in human skeletal remains. Academic Press, New York, 2003; 662 pp.

Osztás A, Zalai-Gaál I, Bánffy E (2012): Alsónyék-Bátaszék: a new chapter in the research of the Lengyel culture. Documenta Praehistorica 39, 377-396.

Özdoğan M. (2008): An Alternative Approach in Tracing Changes in Demographic Composition. In: Bocquet-Appel, J.-P., Bar-Yosef, O. (Eds.), The Neolithic Demographic Transition and Its Consequences. Springer, pp. 139-178.

Pääbo S, Higuchi RG, Wilson AC. (1989): Ancient DNA and the polymerase chain reaction. The emerging field of molecular archaeology. J Biol Chem 264: 97099712

Pääbo S, Wilson AC. (1988): Polymerase chain reaction reveals cloning artefacts. Nature 334: 387-388

Pääbo S. (1984): Über den Nachweis von DNA in altägyptischen Mumien. Das Altertum 30: 213-218.

Pääbo S. (1985): Molecular cloning of ancient Egyptian mummy DNA. Nature 314: 644-645. 
Pääbo S. (1987): Molecular genetic methods in archaeology - a prospect. Anthropol. Anzeiger 45: 9-17.

Pääbo S., Poinar H., Serre D., Jaenicke-Després V., Hebler J., Rohland N., Kuch M., Krause J., Vigilant L., Hofreiter M. (2004): Genetic analyses from ancient DNA. Annu Rev Genet 38: 645-679.

Pál T. (szerkesztő) (2013): Az orvosi mikrobiológia tankönyve. Mándi Y. 421-430. ISBN: 9789632264639

Pálfi Gy, Bereczki Zs, Ortner DJ, Dutour (2012): Juvenile cases of skeletal tuberculosis from the Terry Anatomical Collection (Smithsonian Institution, Washington, D.C., USA). Acta Biologica Szegediensis 56(1):1-12.

Pálfi Gy, Dutour O, Deák J, Hutás I. (1999): (Eds.) Tuberculosis: Past and Present. Budapest-Szeged: Golden Book Publisher - Tuberculosis Foundation, 1999; 608 pp.

Pálfi Gy, Kristóf L.A, Barta M., Spigelman M., Donoghue H.D., Szikossy I., Pap I. (2003): Observations paléopathologiques sur les momies de deux moniales (XVIIIe siècle, Vac, Hongrie). Colloque 2003 du GPLF, Toulon, France, Résumés.

Pálfi Gy., Ardagna Y., (2002): Gerincbetegségek és tuberkulózis a török hódoltság korából. A Bácsalmás-Óalmás (Bácsalmás-Homokbánya) 16-17. századi antropológiai leletegyüttes fontosabb paleopatológiai adatai. In: Gerelyes I, Kovács Gy (Eds.) A hódoltság régészeti kutatása. Opuscula Hungarica III., Magyar Nemzeti Múzeum, Budapest, 237-244.

Pálfi Gy., Molnár E., Bérato J., Dutour O (1997): Cinq cas de pathologie infectieuse ou inflammatoire dans une série anthropologique hongroise. Anthropologie et Préhistoire, 108, 165-176.

Pálfi G., Dutour O., Perrin P., Sola C., Zink A. (2015): Tuberculosis in Evolution. Tuberculosis, 95: S1-3 DOI:10.1016/j.tube.2015.04.007. 
Pálfi Gy. (2002): Paleoepidemiological reconstruction of tuberculosis, with particular attention to Europe. In: Bennike P., Susanne C. (Eds.), Biennial Books of EAA, Vol. 2: 193-210.

Pálfi Gy., Marcsik A. (1999): Paleoepidemiological data of tuberculosis in Hungary. In: Pálfi, Gy., Dutour, O., Deák, J., Hutás, I. (Eds.), Tuberculosis: Past and Present. TB Foundation, Szeged \& Golden Book Publisher, Budapest, pp. 531-539.

Pálfi Gy., Molnár E., Bérato J., Wicker E., Dutour, O. (1996): Deux observations ostéoarchéologiques de spondylarthrite ankylosante et leur possible relation familiale. Revue du Rhumatisme, 63 (2), 160-161.

Pap I, Józsa L, Repa I, Bajzik G, Lakhani SR, Donoghue HD, Spigelman M (1999): 1819th century tuberculosis in naturally mummified individuals (Vác, Hungary). In: Pálfi G, Dutour O, Deák J, Hutás I (eds) Tuberculosis: Past and Present. Golden Books/Tuberculosis Foundation, Budapest, pp 421-428

Pap I, Susa É, Józsa L. (1997): Mummies from the 18th-19th century Dominican Church of Vác, Hungary. Acta Biol Szegediensis; 42:107-12.

Pap I., Kustár Á., Bernert Zs., Szikossy I., Donoghue H. D., Spigelman M., Hershkovitz I., Kristóf L. A., Barta M., Pálfi Gy. (2002): Paléopathologie rachidienne de deux momies du XVIIIe s. - In: Bérato, J. et al. (éd.), Centre Archéologique du Var, 2001 (Toulon, France), pp. 40-42.

Perlès C. (2005): From the Near East to Greece: let's reverse the focus - cultural elements that did not transfer. In: Lichter, C. (Ed.), BYZAS 2. How Did Farming Reach Europe? Anatolian-European Relations from the Second Half of the 7th through the First Half of the 6th Millennium Cal BC. Veröffentlichungen Des Proceedings of the International Workshop Istanbul, 20-22 May 2004. Veröffentlichungen des Deutschen Archäologischen Instituts Istanbul. Ege Yayinlari, Istanbul, pp. 275-290.

Pinhasi R, Fernandes D, Sirak K, Novak M, Connell S, Alpaslan-Roodenberg S, et al. (2015): Optimal Ancient DNA Yields from the Inner Ear Part of the Human Petrous Bone. PLoSONE 10(6): e0129102. doi:10.1371/journal.pone.0129102 
Pinhasi R., (von) Cramon-Taubadel, N. (2009): Craniometric data supports demic diffusion model for the spread of agriculture into Europe. PloSONE 4, e6747.

Pohl W. (2002): Die Awaren - Ein Steppenvolk in Mitteleuropa 567-822 n. Chr, München 2002, ISBN 3-406-48969-9, pp 21-27.

Pósa A, Frank M, Sola C, Bereczki Z, Molnár E, Masson M, Lovász G, Wicker E, Perrin P, Dutour O, Zink A, Pálfi G (2015a): Tuberculosis infection in a latemedieval Hungarian population. Tuberculosis 95(Suppl 1):S60-S64. DOI: 10.1016/j.tube.2015.02.010.

Pósa A, Maixner F, Lovász G, Molnár E, Bereczki Zs, Perrin P, Zink A, Pálfi Gy. (2013): Revision of tuberculous lesions in the Bácsalmás-Óalmás series preliminary morphological and biomolecular studies. Anthropologischer Anzeiger, 70, 1: 83-100., pp. 83-100

Pósa A, Maixner F, Mende BG, Köhler K, Sola C, Dutour O, Masson M, Molnár E, Pálfi G, Zink A (2015b): Tuberculosis in Late Neolithic-Early Copper Age human skeletal remains from Hungary. Tuberculosis 95(Suppl 1):S18- S22. DOI: 10.1016/j.tube.2015.02.011.

Pósa A, Maixner F, Zink A, Lovász G, Molnár E, Bereczki Zs, Perrin P, Dutour O, Sola C, Pálfi Gy. (2012a): Ancient human tooth samples used for TB paleomicrobial research. Acta Biologica Szegediensis Volume 2012; 56(2):125-131

Pósa A., Köhler K., Maixner F., Zink A., Sola Ch., Pálfi Gy., Mende B. G. (2014): Molecular and morphological case of Pott's disease from the Árpádian-Era. The $19^{\text {th }}$ Congress of the European Anthropological Association, Moscow, Russia konferencia, e-poszter

Pósa A., Mende B. G., Köhler K., Osztás A., Maixner F., Zink A., Sola Ch., Dutour O., Molnár E., Pálfi Gy. (2016a): Tuberkulózis nyomai késő neolitikum-kora rézkori emberi maradványokon (Alsónyék-Bátaszék, Dél-Magyarország). Anthrop. Közl. 57; 29-39. DOI: 10.20330/AnthropKozl.2016.57.29. 
Pósa A., Köhler K., Maixner F., Zink A., Sola Ch., Mende B. G. (2016b): Egy Árpádkori temetőben fellelt Pott gibbus-os eset molekuláris és morfológiai vizsgálata. Mesterházy Károly emlékkötet (megjelenés alatt)

Pósa A., Maixner F., Zink A., Lovász G., Molnár E., Bereczki Zs., Perrin P., Dutour O., Sola Ch., Pálfi Gy. (2013): Archaikus humán fogminták alkalmazása a tbc paleomikrobiológiai kutatásában. Természet-, müszaki- és gazdaságtudományok alkalmazása 12. nemzetközi konferencia. 2013.05.11. Szombathely, NyugatMagyarországi Egyetem

Prüfer K., Stenzel U., Hofreiter M., Pääbo S., Kelso J., Green R. E. (2010): Computational challenges in the analysis of ancient DNA. Genome Biol. 2010; 11(5): R47.Published online 2010 May 6. doi: 10.1186/gb-2010-11-5-r47

Raff J, Cook DC, Kaestle F (2006): Tuberculosis in the New World: a study of ribs from the Schild Mississippian population, West-Central Illinois. Mem Inst Oswaldo Cruz 101:25-27.

Rafi A., Spigelman M., Stanford J., Lemma E., Donoghue H.D., Zias J. (1994): Mycobacterium leprae DNA from ancient bone detected by PCR. The Lancet, 343, 8909: 1360-61.

Raoult D, Drancourt M, (eds). (2008): Paleomicrobiology: past human infections. SpringerÐVerlag GmbH, Berlin, Heidelberg

Renfrew C. (1987): Archaeology and Language. The Puzzle of Indo-European Origins. Cambridge University Press, Cambridge.

Resnick D., Niwayama G. (1995): Osteomyelitis, septic arthritis and soft tissue infections: organisms. In: Resnick D., editor. Diagnosis of bone and joint disorders. W. B. Saunders; Edinburgh: 1995. pp. 2448-2558.

Richards M., Macaulay V., Sykes B., Pettitt P., Hedges R.E.M., Forster P., Bandelt H.J. (1997): Reply to Cavalli-Sforza and Minch. American Journal of Human Genetics 61, 251-54. 
Rizzi E, Lari M, Gigli E, De Bellis G, Caramelli D. (2012): Ancient DNA studies: new perspectives on old samples. Genetics Selection Evolution, Volume 44, Number 1, Page 1

Roberts C., Lucy D., Manchester K. (1994): Inflammatory lesions of ribs: an analysis of the Terry Collection. Am. J. Phys. Anthrop., 95: 169-182.

Robson A. J. (2010): A bioeconomic view of the Neolithic transition to agriculture. Canadian Journal of Economics/Revue canadienne d'économique, Volume 43, Issue, pp 280-300

Rohland N, Siedel H, Hofreiter M. (2009): A rapid column-based ancient DNA extraction method for increased sample throughput. Molecular Ecology Resources, Nov. 1755-0998.2009.02824.x

Rothschild BM, Martin LD, Lev G, Bercovier H, Bar-Gal GK, Greenblatt Ch, Donoghue HD, Spigelman M, Brittain D (2001): Mycobacterium tuberculosis Complex DNA from an Extinct Bison Dated 17,000 Years before the Present. Clinical Infectious Diseases 33:305-11

Ryan KJ, Ray CG (editors) (2004): Sherris Medical Microbiology (4th ed.). McGraw Hill. pp. 409-12. ISBN 0-8385-8529-9. DOI: 10.1036/0838585299

Salo W., Aufderheide A., Buikstra J., Holcomb T. (1994): Identification of Mycobacterium tuberculosis DNA in a pre-Columbian Peruvian mummy. Proc. Natl. Acad. Sci. USA, 91: 2091-2094.

Sanger F; Coulson AR (1975): A rapid method for determining sequences in DNA by primed synthesis with DNA polymerase. J. Mol. Biol. 94 (3): 4418.doi:10.1016/0022-2836(75)90213-2. PMID 1100841.

Sanger F; Nicklen S; Coulson AR (1977): DNA sequencing with chain-terminating inhibitors. Proc. Natl. Acad. Sci. U.S.A. $74 \quad$ (12): 54637.Bibcode:1977PNAS...74.5463S. doi:10.1073/pnas.74.12.5463. PMC 431765. PMID 271968. 
Schuenemann VJ, Singh P, Mendum TA, Krause-Kyora B, Jäger G, Bos KI, Herbig A, Economou C, Benjak A, Busso P, Nebel A, Boldsen JL, Kjellström A, Wu H, Stewart GR, Taylor GM, Bauer P, Lee OY, Wu HH, Minnikin DE, Besra GS, Tucker K, Roffey S, Sow SO, Cole ST, Nieselt K, Krause J. (2013): Genomewide comparison of medieval and modern Mycobacterium leprae. Science. 2013 Jul 12;341(6142):179-83. doi: 10.1126/science.1238286. Epub 2013 Jun 13.

Schultz M. (1999): The role of tuberculosis in infancy and childhood in prehistoric and historic populations. In: Pálfi Gy., Dutour O., Deák J., Hutás I. (Eds.), Tuberculosis: Past and Present. Golden Book - TB Foundation, Budapest Szeged, pp. 501-507.

Siklósi Zs. (2010): A társadalmi egyenlőtlenség nyomai a késő neolitikumban a Kárpátmedence keleti felén. Doktori disszertáció, Eötvös LorándTudományegyetem, Bölcsészettudományi Kar, Budapest.

Smith I. (2003): Mycobacterium tuberculosis pathogenesis and molecular determinants of virulence. Clin Microbiol Rev. 2003 Jul;16(3):463-96.

Smith N. H., Kremer K., Inwald J., Dale J., Driscoll J. R., Gordon S. V., (van) Soolingen D., Hewinson R. G., Smith J. M. (2006): Ecotypes of the Mycobacterium tuberculosis complex. J Theor Biol. 2006 Mar 21;239(2):220-5. Epub 2005 Oct 20.

Spekker O., Pálfi G., Kozocsay G., Pósa A., Bereczki Zs., Molnár E. (2012): New cases of probable skeletal tuberculosis from the Neolithic period of Hungary - A morphological study. Acta Biol Szeged 56(2):115-123.

Spigelman M, Donoghue HD (1999): Mycobacterium tuberculosis DNA in archaeological specimens. In Pálfi Gy, Dutour O, Deák J, Hutás I eds., Tuberculosis: Past and Present. TB Foundation, Golden Book Publisher Ltd, 353360.

Spigelman M., Lemma E. (1993): The use of the polymerase chain reaction (PCR) to detect Mycobacterium tuberculosis in ancient skeletons. Int J Osteoarch 3:137143. 
Steinbock RT. (1976): Paleopathological diagnosis and interpretation: Bone disease in ancient human populations. Springfield, Illinois: Charles Thomas.

Stone A. C., Wilbur A. K., Buikstra J. E., Robert C. A. (2009): Tuberculosis and leprosy in perspective. Yearboook of physical anthropology, 52:66-94

Suresh N, Singh UB, Arora J, Pant H, Seth P, Sola C, Rastogi N, Samantaray JC, Pandey JN (2006): rpoB gene sequencing and spoligotyping of multidrug resistant Mycobacterium tuberculosis isolates from India. Infect Genet Evol 6: 474-483.

Szécsényi-Nagy A. (2015): Molecular genetic investigation of the Neolithic population history in the western Carpathian Basin (Molekulargenetische Untersuchungen zur Bevölkerungsgeschichte des Karpatenbeckens). Johannes Gutenberg Universiät, Mainz

Szikossy I., Kustár Á., Guba Zs., Kristóf L.A., Pap I. (2007): Natürlich mumifizierte Leichname aus der Dominikanerkirche von Vác, Ungarn., - In: Wieczorek A., Tellenbach M., Rosendahl W. (eds.) Mumien - Der Traum der ewigen Leben. Mannheim, pp. 155-166.

Szikossy I., Kustár Á., Pálfi Gy., Kristóf L.A., Horányi I., Karlinger K., Kovács B., Riedl E., Spigelman M., Donoghue H.D., Dutour O., Coqueugniot H., Pap I. (2012): The nun without heart - A TB case from the 18th century, Vác, Hungary. In: Gy Pálfi, Zs Bereczki, E Molnár, O Dutour (Eds.): ICEPT-2 The past and present of Tuberculosis: a multidisciplinary overview on the origin and evolution of TB. Szeged, JATEPress, p 94.

T. Biró K. (2003): A termelő gazdálkodás kezdetei Magyarországon. In Bartosiewicz L., T. Biró K., Jerem E., Laszlovszky J., Nagy M., Révész L., Vaday A., Vida T., M. Virág Zs., Visy Zs., Wollák K. Magyar régészet az ezredfordulón ISBN 963 8629107 7.77-78.

Taylor GM., Goyal M., Legge AJ., Shaw RJ., Young D. (1999): Genotypic analysis of Mycobacterium tuberculosis from medieval human remains. Microbiology 145:899-904. 
Taylor GM., Murphy E., Hopkins R., Rutland P., Chitov Y. (2007): First report of Mycobacterium bovis DNA in human remains from the Iron Age. Microbiology 153:1243-1249.

Taylor GM., Young DB., Mays SA. (2005): Genotypic Analysis of the Earliest Known Prehistoric Case of Tuberculosis in Britain. Journal of Clinical Microbiology, May 2005:2236-2240.

Taylor GM., Crossey, M., Saldanha, J., Waldron, T., (1996): DNA from Mycobacterium tuberculosis identified in mediaeval human skeletal remains using polymerase chain reaction. J Archaeol Sci 23: 789-798

Thierry D., Cave M. D., Eisenach K. D., Crawford J. T., Bates J. H., Gicquel B., Guesdon, J. L. (1990): IS6110 an IS-like element of Mycobacterium tuberculosis complex. Nucleic Acids Research 18, 188.

Trogmayer O. (1975): Das bronzezeitliche Gräbelfeld bei Tápé. Budapest 1975. (FontArchHung)

Tüdőgyógyászati Szakmai Kollégium (2011): Az Egészségügyi Minisztérium szakmai protokollja Tuberkulózisról (1. módosított változat)

Vida T. (2009): „...Kérték, hogy Pannoniaban lakhassanak”. Az avarok letelepedése. Szerk.: Anders A., Szabó M., Raczky P., Régészeti dimenziók. Tanulmányok az ELTE BTK Régészettudományi Intézetének tudományos műhelyéből. A 2008. évi Magyar Tudomány Ünnepe keretében elhangzott előadások. pp. 111-115 ISBN 9789632362311.

Weber Nico doctoral dissertation (2013): Computational Approaches for Analyzing Ancient Genomes and Modern Metagenomes, Tübingen, 2013

Wicker E. (1999): Bácsalmás-Óalmás későközépkori rác temetője. Cumania 15: 25-30.

Wicker E. (2006): Rácok és vlahok a török hódoltság kori Észak-Bácskában. PhD disszertáció ELTE BTK. Történelemtudományi Doktori Iskola, Régészeti Doktori Program. 
Wicker E.(2003): A Serb Cemetery from the Ottoman Era in Hungary. In Archaeology of the Ottoman period in Hungary: Eds.: I. Gerelyes - Gy. Kovács. Budapest: Hungarian National Museum 2003 p. 237-248. (Opuscula Hungarica III.)

Wirth T., Hildebrand F., Allix-Béguec C., Wölbeling F., Kubica T., Kremer K., (van) Soolingen D., Rüsch-Gerdes S., Locht C., Brisse S., Meyer A., Supply P., Niemann S. (2008): Origin, Spread and Demography of the Mycobacterium tuberculosis Complex. PLoS Pathog $4 \quad$ (9): 1000160. doi:10.1371/journal.ppat.1000160.

World Health Organization (2011): Global tuberculosis control: surveillance, planning, financing. WHO Report, Geneva, 2011, TB/HIV Fact Sheet. WHO, 2011

World Health Organization (2014): WHO Global Tuberculosis Report 2014. http:// www.who.int/tb/publications/global_report/en/

World Health Organization (2016): WHO Global Tuberculosis Report 2016. http://www.who.int/tb/publications/global_report/en/

Zalai-Gaál I. (2001): A késői neolitikum története a Dél-Dunántúlon a temetőelemzések tükrében (tipológia - kronológia - társadalomrégészet). Akadémiai doktori értekezés. Budapest.

Zalai-Gaál I. (2008): An der Wende vom Neolithikum zur Kupferzeit in Transdanubien (Ungarn): Die "Häuptlingsgräber" der Lengyel-Kultur in Alsónyék-Kanizsa-dűlő. Das Altertum 53:241-280.

Zalai-Gaál I, Osztás A. (2009): Neue Aspekte zur Erforschungdes Neolithikums in Ungarn. Ein Fragenkatalog zu Siedlung und Gräberfeld der Lengyel-Kultur von Alsónyék, Südtransdanubien. In Zeiten - Kulturen - Systeme. Gedenkschrift für Jan Lichardus, Becker V, Thomas M, Wolf-Schuler A (Hrsg.) ZAKS Bd. 17: Langenweißbach; 2009; 111-139.

Zink A, Grabner W, Nerlich AG (2005): Molecular identification of human tuberculosis in recent and historic bone tissue samples: the role of molecular techniques for the study of historic tuberculosis. Am J Phys Anthropol 126:32-47. 
Zink A, Haas CJ, Hagedorn HG, Szeimies U, Nerlich A (1999): Morphological and molecular evidence for pulmonary and osseous tuberculosis in a male Egyptian mummy. In Pálfi Gy, Dutour O, Deák J, Hutás I eds., Tuberculosis: Past and Present. TB Foundation, Golden Book Publisher Ltd, 379-382.

Zink A, Haas CJ, Reischl U, Szeimies U, Nerlich AG. (2001): Molecular analysis of skeletal tuberculosis in an ancient Egyptian population. J Med Microbiol 2001; 50:355-366

Zink A, Molnár E, Motamedi N, Pálfi G, Marcsik A, Nerlich. (2007): A Molecular History of Tuberculosis from Ancient Mummies and Skeletons. Int $J$ of Osteoarchaeol, 2007; 17:380-391.

Zink A, Sola C, Reischl U, Grabner W, Rastogi N, Wolf H, Nerlich AG. (2003): Characterization of Mycobacterium tuberculosis complex DNAs from Egyptian mummies by spoligotyping. J Clin Microbiol 41:359-367.

Zvelebil M. (1998): Genetic and cultural diversity of Europe: a comment on CavalliSforza. Journal of Anthropological Research 54, 411-17.

Zvelebil M. (2000): The social context of the agricultural transition in Europe. In: Renfrew, C., Boyle, K. (Eds.), Archaeogenetics: DNA and the Population Prehistory of Europe. McDonald Inst., Cambridge.

Zvelebil M. (2001): The agricultural transition and the origins of Neolithic society in Europe. Documenta Praehistorica 28, 1-26. 


\section{8 Összefoglaló}

A tuberkulózis (tbc) az egyik legrégebbi fertőző betegség, a megbetegedések száma napjainkban is nagy méreteket ölt (Ortner, 2003; Gutierrez et al, 2005; Hershkovitz et al, 2008; Donoghue, 2009; Baker et al, 2015; Donoghue et al, 2015; Pálfi et al, 2015). A tuberkulózis pandémiás megjelenésü, a WHO becslései szerint jelenleg a Föld népességének mintegy 30\%-a látens Mycobacterium tuberculosis hordozó lehet. Emiatt, és a tényleges megbetegedések (10,4 millió), halálesetek (1,8 millió) magas száma miatt a tbc kutatás rendkívül nagy jelentőséggel bír.

Sokáig úgy tartották, hogy a Mycobacterium tuberculosis a Mycobacterium bovisból alakult ki, a szarvasmarhafélék domesztikációja révén, s fertőzte meg az emberi populációkat (pl.: Cockburn, 1963; Ortner, 1999). Ez a hipotézis egészen a kétezres évek elejéig tartotta magát, ekkor a molekuláris genetikai kutatások több tanulmány révén rávilágítottak arra, hogy a Mycobacterium tuberculosis ősibb változat, mint a $M$. bovis (pl.: Brosch, 2002; Filliol et al, 2006; Hershberg et al, 2008). Az is valószínüsíthető, hogy a Mycobacterium tuberculosis komplex tagjai egy közös őstől, a Mycobacterium prototuberculosis-tól származik (Brosch et al, 2002), amely együtt evolválódhatott az emberiséggel (Camus et al, 2002; Gutierrez et al, 2005; Brisse et al, 2006; Wirth et al, 2008; Weber doktori disszertáció, 2013; Comas et al, 2013; Bos et al, 2014; Boritsch et al, 2014).

A humán tuberkulózis paleopatológiája nagy múlttal rendelkezik (pl.: Bartels, 1907; Steinbock, 1976; Ortner, 1999, 2003; Pálfi et al, 1999), hagyományosan a tbc-s csontváz előrehaladott formáira fókuszált és annak tipikus elhelyezkedésére. A tbc-s csontvázon a tipikus lokalizáció a spondylitis tuberculosa (vagy másnéven Pott-gibbus) és az ízületek tuberkulózisa (pl.: csípő és térd). Az utóbbi időben a paleopatológia megkülönbözteti a tbc-s csontváz előrehaladott és a korai szakaszban lévő formáit, valamint molekuláris biológiai módszereket használ az archaikus mycobacterialis DNS kimutatására.

A 1990-es évektől a Mycobacterium tuberculosis okozta fertőzés azonosítására molekuláris biológiai módszereket is alkalmaznak. A paleomikrobiológiai kutatás képes 
azonosítani a mycobacteriális DNS-t az ásatag humán maradványokból. A tbc evolúciójáról paleomikrobiológiai vizsgálatok adhatnak bővebb információt. Doktori értekezésem első részében röviden áttekintettem a tuberkulózis paleomikrobiológiai kutatásának bő két évtizedes történetét, azok legfontosabb állomásait, eredményeit, alkalmazott módszereit.

Az elmúlt két évtizedben különböző emberi maradványokat használtak mintaként a MTB archaikus DNS kutatása során. Sok esetben a fogak alkalmasabbak lehetnek az aDNS vizsgálathoz, mivel a fogpulpa belső, a külvilágtól elzárt üregében nagyobb a prezerváció valószínűsége (Pósa et al, 2012a). Ideális esetben a külső zománcréteg képes megvédeni a fogbélben található DNS maradványt (Nguyen Hieu et al. 2011).

Mivel a szakirodalomban aránylag jelentős a morfológiai alapon azonosított, gümőkórral fertőzött hazai paleopatológiai esetek száma (pl.: Pálfi et al, 1999; Marcsik et al, 2009), ezért aktuálissá vált, hogy a technikai fejlődésnek megfelelően, molekuláris vizsgálatokkal is alátámasszuk ezen adatokat.

Ahhoz, hogy megfigyelhessük a tuberkulózis időbeli/térbeli terjedését, szükséges különböző korszakokban nyomon követni a fertőzések jelenlétét, egy-egy adott időintervallumot kijelölve. Így viszonylag jó rálátást kaphatunk az epidemiológiai adatokról. Paleomikrobiológiai kutatásaim során ezeket a szempontokat is figyelembe véve vizsgáltam a Kárpát-medencében a tbc aDNS előfordulási/gyakorisági adatait.

A tbc előfordulásának tisztázásához 6 jól elkülöníthető korszakot vizsgáltam. Ezek közül a legkorábbi, és a Mycobacterium tuberculosis evolúcióval kapcsolatban talán a legfontosabb a neolitikum.

Alsónyék-Bátaszék feltárására 2006 és 2009 között került sor, ahol egy prehisztorikus temető maradványira bukkantak. Jelentőségét az adja, hogy jelenleg az itt bemutatott temető az egyik legrégebbi és legnagyobb neolitkori település KözépEurópában. A 2359 temetkezés a Késő Neolit/Korai Rézkorból származik (Kr. e. 5000) (Köhler et al, 2013). Az Alsónyék-Bátaszék lelőhelykomplexum része az AlsónyékKanizsa dűlő, amely a Lengyel kultúrából származik, itt 862 sírt tártak fel (Zalai-Gaál és Osztás, 2009). A másik tanulmányozott neolit temető - Vésztő-Mágori domb - a 
Tiszai kultúrából származik, ugyanazon korszakból. Az előzetes morfológiai vizsgálatok mindkét lelőhelyről valószínűsíthető tbc-előfordulást jeleztek.

Kutatásaim során kisebb mennyiségü mintát teszteltem Tápé-Széntéglaégető lelőhely késő bronzkori temetőjéből (Kr. e. 14-13. század) is. Az SZTE Embertani Tanszékén a közelmúltban megkezdett paleopatológiai vizsgálatok során hét egyén esetében bukkantak tbc-vel összefüggésbe hozható atípusos tünetekre. Biomolekuláris vizsgálataim számára ez a hét eset szolgáltatott mintát.

A Szeged-Kiskundorozsma Kettőshatár II. avar kori széria paleopatológiai vizsgálata során a 263-as sírból származó csontmaradványokon atípusos tbc-re utaló elváltozásokat találtak az SZTE Embertani Tanszék munkatársai. Paleomikrobiológiai doktori kutatásaim lehetőséget teremtettek ennek az esetnek az elemzésére is, hasonlóan egy másik, szintén avar kori, szintén atípusos tbc-s vázmaradvány mintájához, Csárdaszállás-Hanzélytanya lelőhelyről.

Az 1970 és 1973 között Győr-Pósdomb lelőhelyen feltárt Árpád-kori temető 187es sírszámú Pott-gibbus-os esetét vizsgáltuk molekuláris biológiai módszerekkel, a csontvázon fellelt súlyos morfológiai elváltozások igazolására.

Kutatásaim fontos anyagát jelentette a Bácsalmás-Óalmás régészeti lelőhelyről származó (16-17. század), 1993-2003 között 3 fázisban feltárt embertani anyag (Wicker, 2006). A késő-középkori népcsoport balkáni eredetü, vallási okból viszonylag endogám közösséget alkottak (Wicker et al, 1999). A feltárások során összesen 481 egyén jó megtartási állapotú, csontvázmaradványai kerültek elő (Lovász, 2005a, 2009, 2013). A szériában megfigyelt nagyszámú tbc-re utaló morfológiai elváltozás orientálta a paleomikrobiológiai mintavételt.

Kutatásaim egyetlen újkori alanya mumifikálódott emberi maradvány volt. A váci Fehérek temploma 1994-es restaurálásakor bukkantak az Európában is egyedülálló természetesen mumifikálódott emberi maradványokra: a domonkos rendi altemplomban 265 díszes koporsókban eltemetett, részben vagy teljesen mumifikálódott holttestre bukkantak (Pap et al, 1997). Munkánk során a Sándor Terézia mumifikálódott 
holttestén végeztünk molekuláris biológiai vizsgálatokat Mycobacterium tuberculosis aDNS kimutatása érdekében.

$\mathrm{Az}$ alsónyéki neolit széria esetében a molekuláris vizsgálatokba 38 egyén csontvázát vontuk be, a vizsgálatok alapján 5 egyénnél kaptunk a fogakból és/vagy hosszúcsontokból pozitív eredményt baktérium DNS vizsgálatára. Az eredmények jelzik, összhangban a molekuláris biológiai kutatásaimmal párhuzamosan publikált morfológiai adatokkal (Köhler doktori disszertáció, 2012; Köhler et al, 2013), hogy a Mycobacterium tuberculosis fertőzés jelen volt az alsónyéki prehisztorikus populáció temetkezésére használt, általunk tanulmányozott sírcsoportjából előkerült emberi maradványokban (Pósa et al, 2015b). Eredményeim alátámasztják Masson és munkatársai által közölt magyarországi neolit tuberkulózis-előfordulással kapcsolatos, közelmúltban közölt adatokat (Masson et al, 2013, 2015), és számos új esettel kiegészítve konfirmálják a MTBC jelenlétét és humánpatogén mivoltát a mintegy 7000 évvel ezelőtti Közép-Európában. A Tiszai kultúrából származó Vésztő Mágori-domb lelőhelyről származó csontoknál egy esetben igazoltuk a tbc-baktérium aDNS maradvány jelenlétét, ezzel bizonyítva a lelet mycobacteriális fertőzését.

A bronzkorból és avar korból származó minták esetén nem tudtuk igazolni a fertőzöttséget, ami arra enged következtetni, hogy az aDNS nagymértékben degradálódott. Ez rámutat arra, hogy a jövőben szükségessé válik az újgenerációs szekvenálási eljárások bevonása az ilyen jellegű vizsgálatokba, a vizsgálati minták bővítése mellett.

Az Árpád-kori temető 187-es egyén esetében megfigyelhetők a fertőzés nyomai a csontokon (bordák, combcsontok, csigolyák érintettsége, jellegzetes Pott-gibbus jelenléte), mycobacteriális DNS jelenléte igazolható a humerus és femur esetében (Pósa et al, 2016b, megjelenés alatt).

A makromorfológiai adatok alapján a Bácsalmás-Óalmási temető egyedeinél a vizsgált 481 csontvázból 283 lehetséges tbc-fertőzött esetet jegyeztek fel az antropológusok, melyek magukba foglalják a tipikus és az atipikus elváltozásokat is, ezek részletes közlése Kajdocsi Lovász Gabriella doktori disszertációjában található (Lovász, 2015). A molekuláris biológiai vizsgálat alá vetett 18 egyénből 7 egyénnél 
igazolható a Mycobacterium jelenléte DNS alapon, 56 minta feldolgozása alapján (Pósa et al, 2015a). A teljes széria biomolekuláris vizsgálatát, annak rendkívüli költség-, és időigénye miatt nem végezhettük el, de a populáció magas tbc-fertőzöttségi rátája így is igazolást nyert. Új eredményeink alátámasztják több korábbi tanulmány adatait, melyek már a bácsalmási széria magas tbc prevalenciáját sejtették (Pálfi és Ardagna, 2002; Zink et al, 2007). A spoligotyping különböző típusú MTBC fertőzéseket jelzett a szériában, de a degradáltsági fok miatt pontos Mycobacterium fajmeghatározást (M. bovis, $M$. tuberculosis) nem tett lehetővé, így azt csak megerősítő vizsgálatként kezelhettük.

$\mathrm{Az}$ újkori váci múmia esetében megerősítést nyertek a korábban publikált eredmények, miszerint a váci Fehérek templomában eltemetett egyének körében gyakori volt a tbc-fertőzöttség (Fletcher et al, 2003; Donoghue et al, 2011). A múmia bőr-foszlányaiból sikeresen izoláltunk és azonosítottunk Mycobacterium tuberculosis DNS-maradványokat.

Kutatási programunk során eredményesen alkalmaztuk hazai mintákon a nemzetközi gyakorlatban bevált paleomikrobiológiai technikákat, és négy különböző korszakban is bizonyítottuk a tuberkulózis fertőzöttséget. Jól megfigyelhető, hogy az emberi társadalmat végigkíséri a betegség - tanulmányaink alapján bizonyíthatóan legalább hétezer éve. Már az újkőkorban is jelen volt hazánk területén a gümőkór, így érdekes téma lehetne, ha még korábbi korszakok vizsgálatára is lehetőségünk nyílna a következő évek során.

Vizsgálataim rávilágítottak arra is, hogy a mycobacteriális DNS megőrződése valamivel jobb a hosszúcsontok és a fogak esetében, mint a csigolyákban vagy a bordákban. Ugyanakkor arra is rámutatnak a kapott adatok, hogy milyen fontos a megfelelő minta kiválasztása, a helyszínen történő párhuzamos mintavétel: egy-egy egyén esetében a hosszúcsontok és fogak párhuzamos alkalmazása a molekuláris vizsgálatok során.

Annak érdekében, hogy vizsgálataink során még reprezentatívabb eredményeket kaphassunk, kiemelt fontosságú a pontos és körültekintő mintavételezés, hiszen egy populáció szintjén nem szükséges az összes egyén vizsgálata. A jövőben további vizsgálatokra, ill. új generációs szekvenálási technikák bevonására lesz szükség, hogy 
pontosabb képet kaphassunk az eddig vizsgált szériák és jövőben tanulmányozni kívánt leletegyüttesek esetében. A módszerrel korlátozható, ill. kizárható lesz a kontamináció veszélye, megvalósulhat a talajban lévő mycobacteriumok és a humánpatogén Mycobacterium fajok pontosabb elkülönítése, és az egykori Mycobacterium DNS jelenlétének konfirmálásán túl lehetőség nyílik az ősi törzsek karakterizálására, evolúciós kérdéseik tisztázására is.

\section{Summary}

Tuberculosis (TB) is one of the oldest diseases and still has a high prevalence nowadays (Ortner, 2003; Gutierrez et al, 2005; Hershkovitz et al, 2008; Donoghue, 2009; Baker et al, 2015; Donoghue et al, 2015; Pálfi et al, 2015). The disease is pandemic, according to the estimation of the WHO $30 \%$ of total population of the World may be infected latently by Mycobacterium tuberculosis. On one hand, this is a fact, and on the other hand 10.4 million people fell ill with TB and 1.8 million died from the disease, this is why the research of TB so important for mankind.

For a long time it was thought that Mycobacterium tuberculosis was developing from Mycobacterium bovis during domestication and had infected the human population (e.g. Cockburn, 1963; Ortner, 1999). This hypothesis was accepted until the beginning of the 2000s, thereafter more studies revealed that Mycobacterium tuberculosis is a more ancient variant than the M. bovis (e.g. Brosch, 2002; Filliol et al, 2006; Hershberg et al, 2008). It is probable that Mycobacterium tuberculosis complex has a general ancestor, which is the Mycobacterium prototuberculosis (Brosch et al, 2002) which might have developed together with mankind (Camus et al, 2002; Gutierrez et al, 2005; Brisse et al, 2006; Wirth et al, 2008; Weber doctoral dissertation, 2013; Comas et al, 2013; Bos et al, 2014; Boritsch et al, 2014).

The paleopathology of TB has a great antiquity (e.g.: Bartels, 1907; Steinbock, 1976; Ortner, 1999, 2003; Pálfi et al, 1999). It is traditionally focused on the advanced stage forms of skeletal TB and on its typical localisations. The typical localisations of skeletal TB are spondylitis tuberculosa (or Pott's disease) and tuberculosis of big joints (for example: knee and hip). In recent times, paleopathology distinguishes advanced and 
early stage forms of skeletal TB and also uses molecular methods for the detection of ancient mycobacterial DNA.

Since the 1990s, the identification of Mycobacterium tuberculosis infection uses molecular methods, too. Paleomicrobial research is also able to identify mycobacterial DNA from ancient human remains. Paleomicrobial research which was done on ancient human remains can give us more sophisticated information about TB's evolution. In the first part of my doctoral dissertation I shortly review the history of paleomicribiological research of TB, which is more than two decades.

Different elements of ancient human remains were used as samples in MTB aDNA research during the last two decades. The advantage of using dental pulp for aDNA studies holds in its potential better preservation in a closed cavity (Pósa et al, 2012a). In an ideal case, the external enamel layer is able to protect the DNA remains in the dental pulp (Nguyen Hieu et al. 2011).

Since Hungary has plentiful morphologically identified TB cases (e,g, Pálfi et al, 1999; Marcsik et al, 2009), nowadays it is a current issue that these data definitely need supportive molecular biological research.

In order to gain insight into the expansion of $\mathrm{TB}$, it is needed to keep track of the infection's presence during different eras. The most suitable method is the study of epidemical data, to appoint an exact period of time. Therefore I was attentive to these points of views in the pursuance of my research, while I was studying the molecular presence of TB, from Neolithic to modern age, within the Carpathian Basin.

In my examination I researched six historical periods for TB infection, the earliest period is Neolithic, which may give important confirmation for the evolution of Mycobacterium tuberculosis.

The excavation of this prehistoric settlement and cemetery took place between 2006 and 2009, during which 2,359 burial places of the Late Neolithic-Early Copper Age Lengyel culture were found (first half of the 5th millennium BC) (Köhler et al, 2013). This is therefore to date one of the largest late Neolithic sites excavated in Central Europe. The first TB cases came out from the northern, so-called Kanizsa-dülö 
part (or 010/B) of the site, from where the skeletal remains of 862 graves were excavated (Zalai-Gaál \& Osztás, 2009). The other neolithic cemetery came from the Tisza culture - Vésztő - Mágor - from the same time period. The preliminary morphological research indicated possible TB occurrences from both archaeological sites.

During my research I have tested a few samples from Tápé-Széntéglaégető archaeological site, which is a late Bronze Age (BC 14-13 century) cemetery. In the recent past paleopathological research was started on this series in the Department of Biological Anthropology - University of Szeged, and seven individuals were detected for TB related atypical lesions. These cases gave samples for my biomolecular research.

Colleagues of the Department of Biological Anthropology - University of Szeged found atypical TB related lesions on the Avar Age samples (Szeged-Kiskundorozsma Kettőshatár II. (Grave No. 263.) and Csárdaszállás-Hanzélytanya). My paleomicrobiological doctoral research gave opportunity to analyse both samples from the Avar Age.

The cemetery from the age of the Árpádian Dynasty was excavated between 1970 and 1973. In the case of Pott's disease- from grave no. 187 - we noticed severe morphological lesions during the molecular biological analysis of the skeleton.

It was important for my research that the skeletal material came from the Bácsalmás-Óalmás archeological site (AD 16-17th centuries, southern Hungary), excavated in three phases between 1992 and 2003 (Wicker et al, 2006). This ethnic group originated in the Balkans and intermingled with other populations, probably for religious reasons, and their community became closely endogamous (Wicker et al, 1999). This study was carried out on the series of 481 skeletons whose state of preservation was exceptional (Lovász, 2005a, 2009, 2013). In the series there was high prevalence of TB-referring morphological lesions suitable for paleomicribiological sampling.

My research has had only one subject from the modern age. The naturally mummified human remains which are unique in Europe were found in 1994 when the 
restoration of the Dominican church of Vác took place: partially or completely mummified bodies were found in the 265 ornamented coffins (Pap et al, 1997). In our work a molecular biological examination was performed on the body of Terézia Sándor for the detection of Mycobacterium tuberculosis aDNA.

In total 38 individuals of the grave group no. 13 of the Alsónyék-Bátaszék Neolithic cemetery were included in the molecular biological analysis, five individuals showed positive molecular results for bacterial DNA. The molecular detection was successful in samples from long bones and/or teeth (Pósa et al, 2015b). The results were in accordance with my molecularbiological research and the parallel publicised morphological data (Köhler doctoral dissertation, 2012; Köhler et al, 2013) indicate that, the Mycobacterium tuberculosis was present in those human remains which were from the part of the Alsónyék-Bátaszék Neolithic cemetery investigated by us. My results corroborate the Neolithic occurrence of tuberculosis from South-eastern Hungary already published by Masson and colleagues (Masson et al, 2013, 2015), confirming the presence of TB in the Central Europe 7000 years ago with several new cases. Regarding the Vésztő - Mágor neolithic cemetery (originated from the Tisza culture) we confirmed only on one occasion the presence of TB's aDNA remain, to prove the presence of the Mycobacterial infection in this individual.

We could not confirm the infection in the case of the Bronze and the Avar Age samples, it may conclude that aDNA was greatly degraded. This experience pointed to that in the future it will be required to use next-generation sequencing and wider sampling for this kind of research.

The cemetery from the Age of the Árpád Dynasty (Grave No. 187) shows pathological lesion (ribs, femur, vertebrae and Pott's disease), the presence of Mycobacterial DNA can be justified in the case of the humerus and femur (Pósa et al, $2016 b$, in press).

Among the examined 481 skeletons, 283 possible cases of TB infection were recorded based on macro morphological data by anthropologists, also including the typical and atypical alterations, and the itemized paleopathological results were presented in the doctoral dissertation of Gabriella Kajdocsi Lovász (Kajdocsi Lovász 
Gabriella doctoral dissertation, 2015). We have dealt with 56 samples, seven out of the eighteen individuals analysed were positive for the region of IS6110 of M. tuberculosis (Pósa et al, 2015a). Unfortunately, the biomolecular examination of this complete series would be very time-consuming and would require a large amount of funds in order to be completed, however the high TB-infectious rate of the population was proved. Our new results are supporting data of some earlier studies about high TB prevalence in this population (Pálfi and Ardagna, 2002; Zink et al, 2007). The spoligotyping pictures different MTBC pathogens, although the precise Mycobacterium (M. tuberculosis, M. bovis) appearing in these samples could not be identified.

The previously published results were confirmed in the case of Terézia Sándor's mummy, there was frequent infection in those individuals who were buried in the Dominican church of Vác (Fletcher et al, 2003; Donoghue et al, 2011). From the skin remains of the mummy Mycobacterium tuberculosis aDNA remains were isolated and confirmed successfully.

During our research program we successfully adopted long standing paleomicrobiological techniques on the indigenous samples, and the TB infection was confirmed in four different ages. Our studies prove that, this disease has accompanied the human population during its history - for 7000 years at least. The presence of tuberculosis has been proved in Hungary since the neolithic, that is why it would be an interesting research topic if we could analyse more earlier periods in the near future.

My research has revealed that the preservation of mycobacterial DNA is much more extensive in the case of long bones and teeth, than in the case of vertebrae or ribs. At the same time, data gained indicate the importance of the selection of the sample, as well as parallel sampling individually from long bones and teeth.

In order to gain more representative results from our research, the best possible precise sampling is crucial, because on the level of population an utterly individual examination is unnecessary. My additional studies will be completed with nextgeneration sequencing therefore, and will give us more accurate result in comparison with both past examined series and future ones. With this method the hazard of contamination will be limited or excluded. The more precise isolation between the soil 
Mycobacteria and the human pathogenic Mycobacteria strains can materialize, and beyond the confirmation of MTBC DNA presence there will be opportunity for the characterization of the ancient strains and answering the questions concerning their evolution. 


\section{A dolgozat alapjául szolgáló publikációk}

Pósa A., Maixner F., Mende B. G., Köhler K., Osztás A., Sola Ch., Dutour O., Masson M., Molnár E., Pálfi Gy., Zink A. (2015): Tuberculosis in Late Neolithic-Early Copper Age human skeletal remains from Hungary. Tuberculosis 95(Suppl 1):S18- S22. DOI: 10.1016/j.tube.2015.02.011.

IF: 2,952

Pósa A, Maixner F, Sola Ch, Bereczki Zs, Molnár E, Masson M, Lovász G, Spekker O, Wicker E, Zink A, Perrin P, Dutour O, Zink A, Pálfi Gy. (2015a): Tuberculosis infection in a late-medieval Hungarian population. Tuberculosis 95(Suppl 1):S60-S64. DOI: 10.1016/j.tube.2015.02.010

IF: 2,952

Pósa A., Maixner F., Lovász G., Molnár E., Bereczki Zs., Zink A., Pálfi Gy. (2013): Revision of tuberculous lesions in the Bácsalmás-Óalmás series - preliminary morphological and biomolecular studies. Anthropologischer Anzeiger Volume 70, No. 1. p $83-100$

IF: 0,676

\section{A dolgozat témájához kapcsolódó egyéb publikációk}

Lovász G., Pálfi Gy., Marcsik A., Pósa A., Naparáczki E., Molnár E. (2010): Skeletal manifestation of tuberculosis in a late medieval anthropological series from Serbia. Acta Biologica Szegediensis. 54.(2) 83-91.

Neparáczki E., Török T., Pósa A., Molnár E., Lovász G., Maixner F., Zink A., Dutour O., Pálfi Gy. (2011): Preliminary results from the paleomicrobiological studies of Mycobacterium tuberculosis infection in the Bácsalmás-Óalmás anthropological series. Acta Biologica Szegediensis 55.(1) 41-45.

Lovász G., Molnár E., Pálfi Gy., Pós, A., Wicker E. (2012): „Sátorlakó vándorok" a török kori Észak-Bácskában. Bácsország, 2012/1 - (60. szám), 68-73.

Pálfi Gy., Zink A., Maixner F., Pósa A., Lovász G., Wicker E., Bereczki Zs., Molnár E. (2012): Egy késő-középkori embertani széria tuberkulózis fertőzöttségének vizsgálata morfológiai és molekuláris biológiai módszerekkel - TB infection in a late medieval anthropological series - a morphological and biomolecular study. Anthropologiai Közlemények 53: 35-50. 
Spekker O, Pálfi Gy, Kozocsay G, Pósa A, Bereczki Zs, Molnár E. (2012): New cases of probable skeletal tuberculosis from the Neolithic period in Hungary - A morphological study. Acta Biologica Szegediensis, Volume 56(2):115-123, 2012

Pósa A, Maixner F, Zink A, Lovász G, Molnár E, Bereczki Zs, Perrin P, Dutour O, Sola Ch, Pálfi Gy. (2012): Ancient human tooth samples used for TB paleomicrobial research. Acta Biologica Szegediensis Volume 56(2):125-131,

Köhler K., Mende B. G., Pósa A. (2013): A tuberkulózis megjelenése a Dunántúl kései neolitikumában. Magyar Régészet 2: Paper 1. 5 p.

Spekker O., Pósa A., Pálfi Gy., Zink A., Maixner F., Bereczki Zs., Molnár E. (2013): Specifikus fertőző megbetegedés diagnózisa Vésztő Mágori-halom újkőkori leletein. Anthropologiai Közlemények 54: pp. 77-92.

Pósa A., Köhler K., Maixner F., Zink A., Sola Ch., Pálfi Gy., Mende B. G. (2014): Molecular and morphological case of Pott's disease from the Árpádian-Era. The $19^{\text {th }}$ Congress of the European Anthropological Association, Moscow, Russia konferencia, e-poszter

Pálfi Gy., Maixner F., Maczel M., Molnár E., Pósa A., Kristóf L. A., Balázs J., Masson M., Paja L., Palkó A., Szentgyörgy R., Nerlich A., Zink A., Dutour, O. (2015): Unusual spinal tuberculosis in an Avar Age skeleton (Csongrád-Felgyő, Ürmös-tanya, Hungary): A morphological and biomolecular study. Tuberculosis 95(Suppl 1):S29S34. DOI: 10.1016/j.tube.2015.02.033.

IF: 2,952

Pósa A., Mende B. G., Köhler K., Osztás A., Maixner F., Zink A., Sola Ch., Dutour O., Molnár E., Pálfi Gy. (2016a): Tuberkulózis nyomai késő neolitikum-kora rézkori emberi maradványokon (Alsónyék-Bátaszék, Dél-Magyarország). Anthropologiai Közlemények 57; 29-39. DOI: 10.20330/AnthropKozl.2016.57.29.

Pósa A., Köhler K., Maixner F., Zink A., Sola Ch., Mende B. G. (2016b): A népvándorláskor fiatal kutatóinak XXIV. konferenciája Esztergom 2014. november 4-6. II. Főszerkesztő: Türk A., Szerkesztette: Balogh Cs., Major B. Studia ad Archaeologiam 
Pazmaniensiae No. 3.2 - Magyar Östörténeti Témacsoport Kiadványok 3.2. BudapestEsztergom 2016, 533-540. ISBN 978-963-9911-63-5 (megjelenés alatt)

Összesített IF: 9,532

MTMT azonosító: 10034148 